Portland State University

PDXScholar

Winter 3-5-2018

\title{
The Antecedents of Local Government Service Delivery Under Crisis Conditions: the Case of Khon Kaen Province, Thailand
}

Sirisak Laochankham

Portland State University

Follow this and additional works at: https://pdxscholar.library.pdx.edu/open_access_etds

Part of the Public Affairs Commons, and the Public Policy Commons Let us know how access to this document benefits you.

\section{Recommended Citation}

Laochankham, Sirisak, "The Antecedents of Local Government Service Delivery Under Crisis Conditions: the Case of Khon Kaen Province, Thailand" (2018). Dissertations and Theses. Paper 4188.

https://doi.org/10.15760/etd.6082

This Dissertation is brought to you for free and open access. It has been accepted for inclusion in Dissertations and Theses by an authorized administrator of PDXScholar. Please contact us if we can make this document more accessible: pdxscholar@pdx.edu. 
The Antecedents of Local Government Service Delivery under Crisis Conditions:

The Case of Khon Kaen Province, Thailand

\author{
by
}

Sirisak Laochankham

\begin{abstract}
A dissertation submitted in partial fulfillment of the requirements for the degree of
\end{abstract}

\author{
Doctor of Philosophy \\ in \\ Public Affairs and Policy
Dissertation Committee:
Bruce Gilley, Chair
Marcus Ingle
Peerasit Kamnuansilpa
Masami Nishishiba
Shawn Smallman

Portland State University 2018 


\begin{abstract}
The aim of this research is to understand local service delivery in Thailand's post2006 national political crisis. The researcher collected qualitative data in four municipalities in Khon Kaen Province. The analytical framework covered five moderating variables: political institutions, civic engagement, political leadership, governance, and political economy. The results were mixed. Local service delivery suffered from weakening electoral mechanisms, suspended local autonomy, weakened civic participation and policy networks, insecure local administrators, worsened centrallocal trust, and the detrimental effect on local economies. However, there were opportunities for improved, or maintained, local service delivery through the lessening of administrative procedures, a fast-track mechanism for citizen complaints, stronger collaboration among local governments and with the private sector, local citizen initiatives, effective local leadership, and increasing trust between local governments and their constituents. In conclusion, national political crisis caused not only negative impacts, but also created opportunities for improving or maintaining local service delivery.
\end{abstract}




\section{Dedication}

I dedicate this dissertation to my mom and dad for always being beside me and encouraging me to make my dream come true. 


\section{Acknowledgments}

Completion of my doctoral program would not have been possible without the financial support of the College of Local Administration, Khon Kaen University (COLAKKU), Thailand and the academic support of the Mark O. Hatfield School of Government, College of Urban and Public Affairs, Portland State University, the United States of America.

My heartfelt thanks to Professor Bruce Gilley, my main advisor, without whose help and guidance I would not have been successful. I am sincerely grateful for all your time and invaluable support and assistance.

My special thanks to Dr. Peerasit Kamnaunsilpa, Founding Dean of COLA-KKU and Dr. Supawattanakorn Wongthanavasu, Dean of COLA-KKU for their unconditional support. They never let me walk alone throughout the entire journey.

I am very grateful to my committee members, Dr. Marcus Ingle, Dr. Masami Nishishiba, Dr. Peerasit Kamnaunsilpa, and Dr. Shawn Smallman, who generously gave their time and worked closely with me throughout my doctoral pursuit. Their thoughtful suggestions and comments were invaluable to my success.

My sincere gratitude to Dr. Sumon Sakolchai, Dr. Kanok Wongtrangan, Dr. Lampang Manmart, Dr. Kulthida Tuamsuk, Dr. Charles Sampson, Dr. Charles Menifield, Dr. Sandy Hodge, and Dr. Charles Keyes for your inspiration and invaluable support along the way. 
To the Mahasirikul family - Mom Nok and Oky - and the Paksanondha family Dr. Pitak, Mom Pornthip, Nong Gift, and Nong Tong. Your generosity to me was overwhelming. Thank you all for your kind support. I will never forget.

My special thanks to Dr. Pornsuree, Dr. Chantra, Dr. Haruetai, and all my friends whom I met at the University of Missouri, Columbia. I feel indebted to Uncle Norrasinh Albert Souvannavong and Auntie Phikul Churat in Portland, Oregon, for their generosity and kindness and for giving me food and a warm bedroom during some of my difficult times in the US.

I am thankful to Ajarn Tony and Ooy, my Thai compatriots at PSU, who were always with me. Also, I can't forget my fellow doctoral program students — Lynn, Dang, Jen, Sara, and all my other friends at PSU. I am grateful to the members of Sudsanan Group and KKU Alumni network: Ajarn Saksuriya, Dr. Anucha, Dr. Grichawat, Dr. Issara, Dr. Wisapat, Dr. Wiwat, Dr. Duangchan, and Dr. Aphiradee.

Thank you, Tony Criswell, for helping me to proofread and edit my work. Thanks to all my colleagues at COLA and KKU and to anyone I have failed to mention. Your support is appreciated more than you know.

Last, but certainly not least, thank you, my family, Mom Supan, Dad Chanthoe, and my brother, Pele, for all your inspiration and unconditional support. Needless to say, I could not have completed this without you. 


\section{Table of Contents}

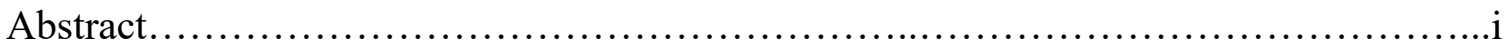

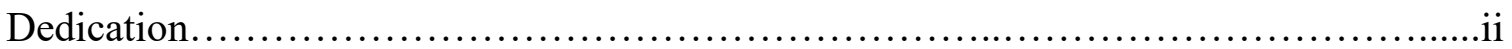

Acknowledgments.............................................................. iii

List of Tables.......................................................................

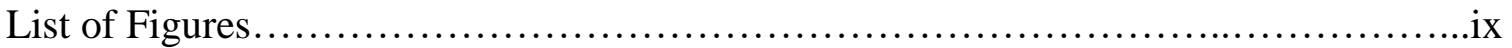

\section{Chapter 1}

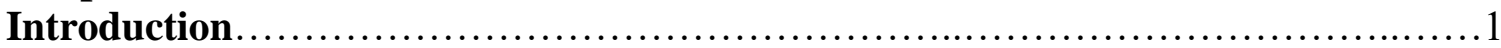

Context of Local Government Service Delivery in Thailand..................... 1

Moderating variables for Local Government Service Delivery................... 7

Research Objective.....................................................12

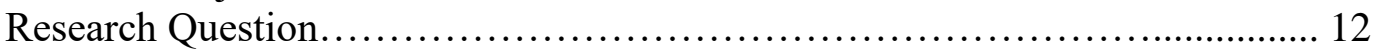

Value of the Study..................................................... 13

Structure of the Dissertation................................................14

\section{Chapter 2}

Background and Literature Review....................................... 15

Local Government Structure and Central-Local Relations......................15

Decentralization and Thailand Local Government System......................19

Impact of Decentralization on Local Service Delivery .........................19

Local Structure and Political Authority.............................20

Local Functional and Administrative Authority.........................21

Local Discretion and Fiscal Authority...............................22

Context of Thailand's Political Crises.....................................23

Thailand's Political Crises in Post-Democracy........................24

Recurrence of Thailand's Political Crisis and the 2006 Military Coup....25

Political Unrest and the 2014 Military Coup............................27

Literature Review.....................................................33

Studies on Effects of Political Crisis on Local Government Service

Delivery.........................................................

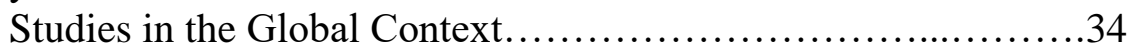

Studies in Thailand Context...................................39

Theoretical Foundations ................................................43

Institutional Theory............................................. 44

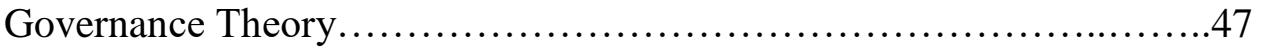

Collaboration................................................ 53

Civic Engagement.......................................58

Public Leadership ............................................61

Political Economy..............................................68 
Conceptual Framework

\section{Chapter 3}

Research Methodology and Design ........................................... 74

Rationale for Exploratory Approach Using a Multiple Case study .................74

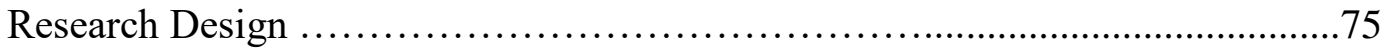

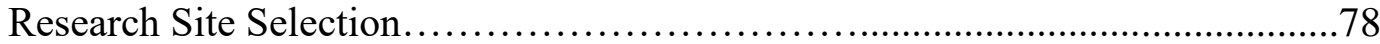

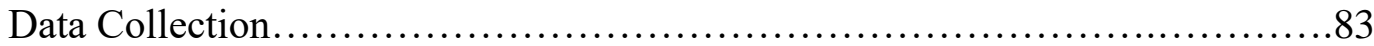

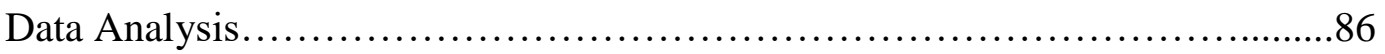

\section{Chapter 4}

How National Political Crisis Creates Threats for Development in Local

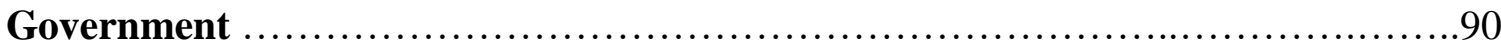

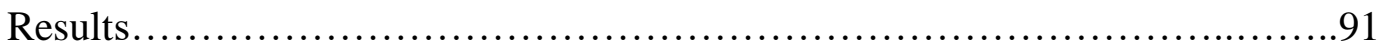

Political Institutions ...........................................

Civic engagement...............................................

Political Leadership.............................................116

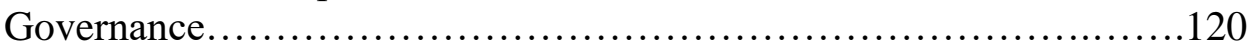

Political Economy............................................... 130

Comparison of the High- and Low-Performance Cases in Dealing with the

Threats Resulting from the National Political Crisis.............................139

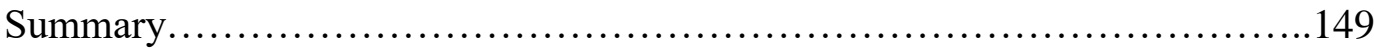

\section{Chapter 5}

How National Political Crisis Creates Opportunities for Development in Local

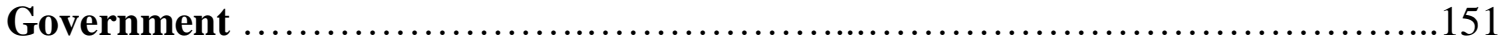

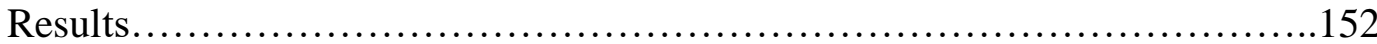

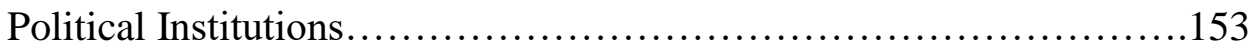

Civic engagement............................................... 158

Political Leadership............................................171

Governance.....................................................

Political Economy...............................................183

Comparison of the High- and Low-Performance Cases in Dealing with the

Opportunities Resulting from the National Political Crisis........................189

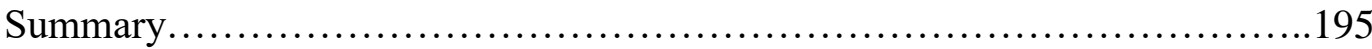

\section{Chapter 6}

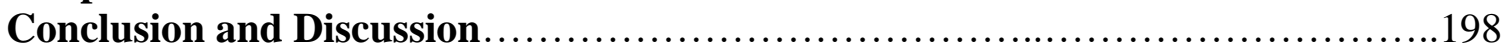

Summary of Findings.................................................... 198

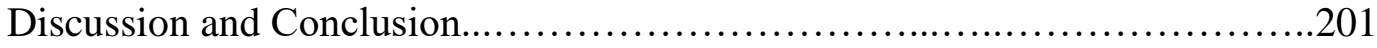

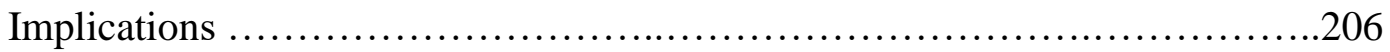


Policy Recommendations...........................................207

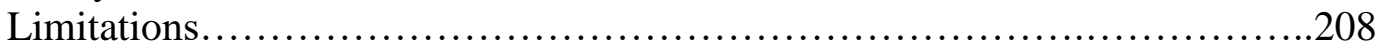

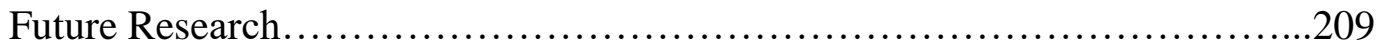

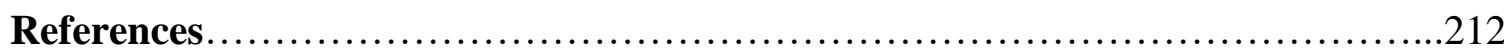

\section{Appendices}

Appendix A. Graphical Representation of Findings: How National Political Crisis Creates Threats to Local Government Service Delivery...228

Appendix B. Graphical Representation of Findings: How National Political Crisis Creates Opportunities to Local Government Service

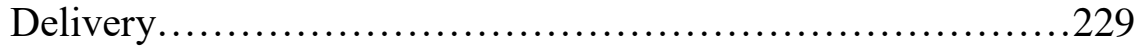

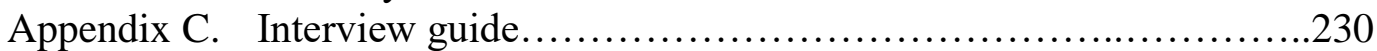

Appendix D. Interview guide (In Thai) .................................236

Appendix E. Informed consent form..................................242

Appendix F. Informed consent form (In Thai)...........................243

Appendix G. Letter of request for interview permission from local government

Appendix H. Letter of request for interview permission from local government

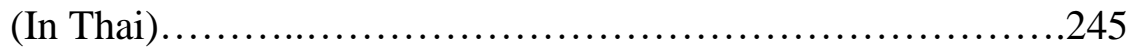

Appendix I. Examples of Codebook for Interview Data Analysis...............246 


\section{List of Tables}

Table 2.1 Theoretical Dimensions of Thailand's Political Crises........................31

Table 3.1 List of Research Sites and Interview's Participants .......................85

Table 4.1 Themes and Samples of Key Responses on Political Institutions..............93

Table 4.2 Themes and Samples of Key Responses on Civic Engagement ..............105

Table 4.3 Themes and Samples of Key Responses on Political Leadership.............117

Table 4.4 Themes and Samples of Key Responses on Governance .....................121

Table 4.5 Themes and Samples of Keys Responses on Political Economy.................131

Table 4.6 Case Performance Analysis (Threats)................................141

Table 5.1 Themes and Samples of Key Responses on Political Institutions..............154

Table 5.2 Themes and Samples of Key Responses on Civic Engagement ................160

Table 5.3 Themes and Samples of Key Responses on Political Leadership.............172

Table 5.4 Themes and Samples of Key Responses on Governance.....................176

Table 5.5 Themes and Samples of Key Responses on Political Economy................184

Table 5.6 Case Performance Analysis (Opportunities).............................189 


\section{List of Figures}

Figure 1.1 Analytical Framework............................................... 8

Figure 2.1 Model of National, Provincial, and Local Relationships in Thailand..........16

Figure 2.2 Thailand Administration Structure................................... 17

Figure 2.3 Local Government Structure and Intergovernmental Relationship............20

Figure 2.4 Timeline of Thailand's National Political Crisis...........................26

Figure 3.1 Map of Khon Kaen Province and Research Sites..............................80 


\section{Chapter 1 \\ Introduction}

\section{Context of Local Government Service Delivery in Thailand}

Public service delivery is recognized as a core responsibility of local governments in Thailand and in many countries around the globe, especially where decentralization is brought into the institutional structure (Denhardt \& Denhardt, 2000; Mansrisuk, 2012; Oates, 1999; Sudhipongpracha, 2014; Varanyuwatana, 2006; World Bank, 2012). In the past, public service delivery was mainly handled by the central government and governmental offices located at provincial and local levels. The patterns of public service offered by government are "one-size-fits-all services," with little consideration of specific needs of citizens who live in different conditions and contexts (Osborne \& Gaebler, 1993, p. 168). Decision-making authority regarding public policy and public expenditures is based on a top-down structure with central government as the main actor in centralized governing processes (Boex et al., 2016).

Due to social complexities and government administration failures, decentralization, as one of governing instruments in governance approach, has prominently influenced government service delivery reform (Oates, 1999). Importantly, decentralizing public service delivery from central to local governments is an important tool for improving government service delivery, enhancing citizen participation, decreasing poverty, and expanding economic development (Channa \& Faguet, 2016; Denhardt \& Denhardt, 2003; Lewis, McCulloch, \& Sacks, 2016; Oates, 1999; Robinson, 
2007). Citizens understand the needs and problems of their local area, so local governments can work closely with them. Local governments play a vital role in providing public services and serving the specific needs of their local residents and can usually perform this role much better than the central government (Lewis, McCulloch, \& Sacks, 2016; Oates, 1999).

In addition, decentralized public service delivery enhances the role of local citizens. Local citizens play a key role in local government affairs. For example, they are involved in political decision-making processes, public policy processes, and even coproduction in public service provision (Osborne \& Gaebler, 1993; Stoker, 1998). As in the case of local citizen involvement in a municipality in northeastern Thailand, local citizens become the main actors in a co-production project- specifically a road construction project. This public service allows local citizens to engage in the service delivery decision-making process and to participate in community activity (Sudhipongpracha \& Wongpredee, 2016).

In general, local government service delivery includes local roads, sanitary facilities, water, garbage collection, hospitals, local security, culture, education, tax collection, etc. (Robinson, 2007; Rodrigues, Tavares, \& Araújo, 2012). For fiscal decentralization autonomy, local governments are allowed to collect taxes and gain revenues from some services, while partial funding comes from the central government. For political decentralization autonomy, local citizens can vote for the mayor and local 
councilors who represent them in local public service operations (Mansrisuk, 2012). This indicates a vital impact of local government service delivery on citizens' roles.

In Thailand, like many developing countries, public service delivery was initially handled by central government (Unger \& Mahakanjana, 2016). The decentralization provision was adopted into the 1997 Constitution in pursuit of improving government service delivery performance, enhancing local self-government, strengthening local democracy, and stimulating economic development (Balassiano, 2011). Consequently, government structure was reformed and centralized public services were transferred to local governments (Mansrisuk, 2012). The main duties of Thailand's local governments include: (1) providing fundamental infrastructure (e.g. road, public transportation, water, sewage, public works, and city planning); (2) developing and sustaining quality of life (e.g. education, public health, recreation area, park, career training, and social welfare); (3) providing community security (e.g. fire protection, consumer protection, and disaster management); (4) promoting local investment, trade, and tourism (e.g. local strategic planning, technology transfer, permit issuance, etc.); (5) protecting and preserving the environment and natural resources (e.g. community forest, pollution, wildfire protection, water protection, etc.); and (6) preserving and promoting local culture, tradition, and wisdom (e.g. local museums and archives, local festivals, etc.) (Thailand Decentralization Plan and Process Act, 1999, B.E. 2542). The background of Thailand's decentralization and local government is further described in Chapter 2. 
Notably, the purposes of decentralizing local government service delivery in Thailand are to promote local self-government, political institutions, civic engagement and citizen empowerment, collective decision-making, political leadership, collaboration, and local economy (Mansrisuk, 2012). These factors reinforce one another and they are instruments for local governments to enhance effective local service delivery. More importantly, political and institutional stability are important factors for maintaining effective local government service delivery performance (North, 1990).

Since 2006, local government service delivery has faced challenges. Recurrent national political crises in Thailand have been a critical concern not only for Thai society but also internationally (Human Rights Watch, 2016; United Nations, 2016; Whiteman, 2014; Yaxley, 2006). The prolonged national political crisis has affected institutional breakdown and economic decline (Norton, 2012; Sussangkarn \& Nikomborirak, 2016)

For an institutional breakdown, political crises have caused government failures and a growing democratic deficit (Kurlantzick, 2011). Importantly, the military interventions - the military coup in 2006 and in 2014- caused constitutional suspensions and set back the progress of full democracy by constituting semi-democracy through constitutional design (Pathmanand, 2008). 
This virtually constant political crisis ${ }^{1}$ tremendously affected the economic downturn because people decreased their spending, while central government suspended some social policies and reduced the expenses of development projects (Sussangkarn \& Nikomborirak, 2016). In addition, political turmoil also created uncertainties for businesses and investors. For example, foreign tourists avoided traveling to Thailand during political protests and investors lacked the confidence to expand their businesses during political turmoil (Sethapramote, 2014; Sussangkarn \& Nikomborirak, 2016).

The effects of Thailand's national political crisis have prompted concerns about its effects on local governments service delivery performance. Due to an institutional relationship and governmental structure, central and local governments in Thailand are not independent from each other. Local governments are considered as arms of central government. Importantly, the central government still influences local governments through political institutional alignment, financial support, and social policy affiliation (State Administration Act of 1991).

Moreover, political crises likely create negative effects on local government service delivery and other public affairs. For example, Madagascar suffered from a prolonged national political crisis during 2009-2014. The effects of this turmoil

\footnotetext{
${ }^{1}$ I recognize that it can be argued that there have been multiple crises since 2006, with two coups, two democratically elected governments, and one government put in place by questionable means during that time. There was unrest during each of the elected governments, so, in effect, there has been a continuous period of turmoil. For that reason, I elected to use the singular crisis when referring to the "post-2006 political crisis" throughout this dissertation.
} 
undermined government public services such as education, health service, food security, and water. In addition, political crises tremendously affect microeconomic activities and induce the decline of public investment (World Bank, 2006). Similarly, in Zimbabwe a 2008 political crisis delayed local political transition. Local governance remained stuck in the old administrative style, resulting in poor local service performance (Bland, 2011).

Little is known about possible positive effects of national political crises in Thailand. In the earlier cited work by Sudhipongpracha and Wongpredee (2016), the local citizens actively engaged in a coproduction project, road maintenance, which was operated collectively among societal actors in the local community. This coproduction project helped transform citizens from "passive citizens" to "proactive citizens" (p.311). As observed, the effects of crises, both political and economic, which occurred in the past have been mixed, creating both positive and negative effects for local governments (Khoman, 2005). Interestingly, many of these studies do not highlight any moderating variables. These variables are influential on improvement of local service delivery performance (Batonon, 2015; Curristine, Lonti, \& Joumard, 2007; UNDP, 2016). The importance of these moderating variables will be described next.

Despite its importance, local government service delivery has often been overlooked in times of national political crisis. Local service delivery is where crisis meets citizen. Obviously, citizens are affected by conflict. With the matters of local government service delivery and concerns of what political crises affect help address the 
research question, "How has Thailand's national political crisis affected local government service delivery?" This study aims to enhance the understanding of the effects of Thailand's prolonged national political crisis on local government service delivery. Then, the study explores the impacts of five moderating variables that influence effective or ineffective performance of local government service delivery.

\section{Moderating Variables for Local Government Service Delivery}

To frame this inquiry, this study focuses on five relevant moderating variables: political institutions, civic engagement, governance, political leadership, and political economy. These five moderating variables are the variables that may influence effective or ineffective local government service delivery performance (Avis, 2016; Lieberman, 2012; Yilmaz et al., 2008; Manda \& Mwakubo, 2013; O’Neil et al., 2014). These variables are thus both practically and theoretically important variables to explore the effects of Thailand's prolonged national political crisis on local government service delivery. These five moderating variables are the factors that interact with political crisis to influence local service delivery process. Since this study is interested in local service delivery as an outcome variable, this study looks at the antecedent conditions for local service delivery rather than local service delivery itself.

To understand why these five moderating variables are important for exploring the effects of national political crisis on local government service delivery, the author will examine them in depth. Core definitions will be provided for each of these variables, key 
reasons for using these variables, their impacts on local service delivery, and at what level in the system do moderating variables operate. In addition, the effects that the national political crisis has had on these variables and how they can affect local government service delivery performance are described. Figure 1.1 helps illustrate the relationship of how national political crisis relate to local government service delivery performance and indicates where these moderating variables are involved.

Figure 1.1 Analytical Framework

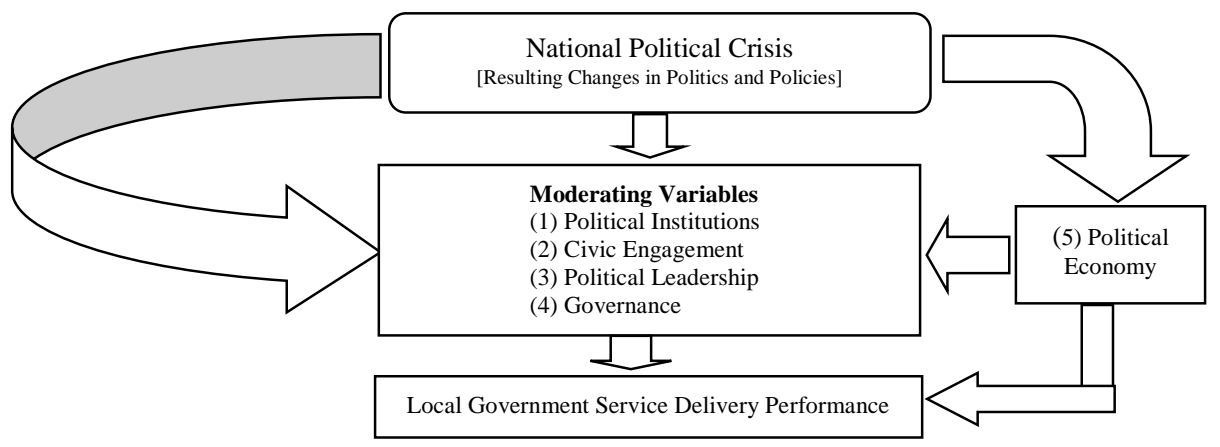

The term "political institutions" refers to the interconnections of individuals or groups within political society mediated by laws and norms that shape human and social interactions (March \& Olsen, 1989). These laws and norms are important institutional instruments that help provide clarity to institutional actors (North, 1990). Political institutions include both formal and informal institutions in the political realm. Formal institutions are the formal laws, constitutions, etc., whereas informal institutions are the norms, social agreement, cultural aspects, etc. These informal institutional tools also shape human interaction (Dobler, 2011; North, 1990). 
This study focuses on formal institutions. Formal political institutions, in this study, are those established by Thailand's constitutions, the State Administration Act of 1991, the Decentralization Plan and Process Act of 1999, Thai national government, public policies, legislature, electoral rules, etc. Formal political institutions are operated at all three levels within governmental structure-national government, provincial administration, and local administration. Informal political institutions are the political norms, political values, political trusts, political participation, political responsiveness, political understanding, etc. (Narayan et al., 2000).

Civic engagement, in this study, refers to patterns and opportunities that local governments provide to their citizens to share their interests in political decision-making processes, public policy processes, and local government service delivery (McLaverty, 2011; Putnam, 1993). This moderating variable is important for this study because active civic engagement helps shape local administration and local community. More importantly, this mechanism assists in providing effective local service delivery and the growth of local values within the community through collective actions (Adler \& Goggin, 2005; Putnam, 1993). This study employs the civic engagement factor to investigate how local citizens engage in political activity, community service or voluntary activity, local coproduction or collective action activity, policy decision-making processes, and network building (Adler \& Goggin, 2005; Pahad, 2005). 
In addition, the researcher employs the spectrum of public participation to examine how and at what level local governments engage citizens in local government service delivery. The spectrum consists of five levels; informing citizens, consulting citizens, involving citizens, collaborating with citizens for decision-making processes, and empowering citizens to make decisions (IAP $\left.{ }^{2}, 2014\right)$. Civic engagement is minimally operated at the national level but is mainly operated in local government and the local community level by emphasizing local government-citizen interactions. In this study, the civic engagement mechanism helps examine whether political institutional breakdown and political fears affect civic engagement in local government service delivery.

Political leadership refers to agency by actors with positional resources intended to improve local service delivery, especially in the contingent situations (Northhouse, 2010; Wart, 2003). In addition, effective political leadership should be able to cope with complicated public problems and uncertain conditions, for instance political crisis. Notably, political leadership requires capacity to maintain political accountability, facilitate local government officers, sustain organizational alignment, and make appropriated decision in public service delivery (Denhardt \& Denhardt, 2011; Fiedler, 1996; Wart, 2003).

This study examines the traditional patterns of political leadership—leaders at the individual level (e.g. local government leaders, local officers, and community leaders) (Boin et al., 2017; Denhardt \& Denhardt, 2000; Denhardt \& Denhardt, 2003). In this 
study, the political leadership factor is operated mainly at the local and community level and it helps examine whether national political crises and institutional breakdowns affect local government service delivery.

Governance variable, as used here, refers to new governing processes in public organizations that emphasize the matters of interdependence between local governments and societal sectors in enhancing effective public service delivery. The analysis within this moderating variable is based upon patterns of new public governance including jurisdictional collaboration, multi-network, and collective actions that local governments employ for improving service delivery (Bevir, 2011; Rhodes, 2007; Stoker, 1998). In this study, the governance variable is operated at the national, provincial, and local levels because the governing processes of local governments are interdependent with all three levels.

Finally, political economy refers to economic conditions that shape incentives and determine the distribution of resources. Political economy perspective emphasizes two dimensions. First, internal political economy focuses on internal mechanisms of economy, i.e. economic processes and norms of efficiency that affect internal mechanisms of the polity such as political structure and processes, political leadership, and political institutions (Stern \& Reve, 1980; Wamsley \& Zald, 1973). Second, external political economy emphasizes external mechanisms of economy, i.e. economic conditions and competitiveness that affect the external mechanism of the polity such as political 
climate, influences of external actors, inter-organizational interactions, and power sharing (Stern \& Reve, 1980; Wamsley \& Zald, 1973). It is important to note that these two dimensions have reinforcing effects on one another. In this study, the political economy variable is operated at the national and local levels because political economy of local governments is interdependent with the national economic conditions.

\section{Research Objective}

This study aims to improve the understanding of the effects of the national political crisis in Khon Kaen Province, Thailand, on local government service delivery. The study examines five moderating variables that interact with the political crisis to influence effective or ineffective local government service delivery performance. Additionally, this study is relevant not only to the cases of the municipality in northeastern Thailand but can also develop a framework for analysis and generate questions as sources for large-scale quantitative and mixed methods research in the future.

\section{Research Question}

To understand whether and how Thailand's national political crisis affect local government service delivery, the overarching research question is: "How has Thailand's national political crisis affected local government service delivery? " In answering this question, the virtually continual national political crisis from 2006 until the study's endpoint in 2016, is an independent variable that impacts local government service 
delivery as an outcome variable. The five moderating variables used in this study are not hypotheses or theories, but rather are widely-studied antecedent conditions that are considered relevant to the study of local service delivery. In addition, this study used five moderating variables to build a framework for inquiry and a system for organizing the data, not to establish a hypothesis based on a particular theory that this study would test. The questions to be answered are whether local government service delivery will experience a negative impact, a positive impact, no impact, or some combination thereof during the political crisis.

\section{Value of the Study}

The impact of this research is both theoretically and practically valuable for the field of public administration and for policy implications. Theoretically, it is useful to understand if the case studies of Thailand's local public service delivery under political crisis could generate a framework for analysis that might have wide applicability to research in political crises and local government service performance, civic engagement, political leadership, local governance, crisis management, political economy or other related theories in public administration and public policy. It is important to emphasize why this study matters: 1) the past ten years and counting of Thailand's history involve political crises; 2) crises in Thailand are recurrent and the current crisis will likely continue and it may shed light on past episodes; 3) there is applicability to other cases in Thailand and other countries. 


\section{Structure of the Dissertation}

This dissertation is organized into six chapters. Chapter 1 presents the introduction and statement of the problem, followed by the research objectives and the research question. The chapter concludes by addressing the significance of the research and dissertation structure. Chapter 2 provides background and literature reviews as well as the theoretical framework. Chapter 3 explains research design methods, chosen research approach, case selection, and data collection and analysis method. Chapter 4 describes the findings on how national political crisis creates threats to local government and demonstrates the case performance analysis. Chapter 5 describes the findings on how national political crisis creates opportunities for local government and demonstrates the case performance analysis. The final chapter, Chapter 6, provides a conclusion and discussion. 


\section{Chapter 2 \\ Background and Literature Review}

This chapter presents the background of Thailand's local government structure and the contemporary context of Thailand's national political crises. The previous research on local government service delivery under political crises that provide the findings of research done in both global context and Thailand's context are addressed. The last part provides the conceptual framework that is built upon three theoretical approaches, including the institutional theory, governance theory (including civic engagement, and public leadership), and political economy theory.

\section{Local Government Structure and Central-Local Relations}

Thailand local government is structured under the concept of the unitary system, which identifies local government as a dependent hierarchical entity within the model of central-local relationships. National government maintains the authority to control and mandate the local government (Agranoff \& Radin, 2014). In Figure 2.1, there are three different circles. Each circle represents a level of governmental jurisdiction. For Thailand, the smallest circle is the local government, which is instituted within the largest circle of national government. The largest circle refers to a single national government that institutionally controls the smaller circles.

The provincial administrative authority in the second circle is the branch of national government and central ministries located at the provincial level. The heads of provincial offices, for instance the provincial governor and chief executive officer of the 
district, are appointed by the national government. They act as supervisors for the local governments, but their authority and responsibilities to provide public services at the local level are mandated by the national government.

Figure 2.1 Model of National, Provincial, and Local Relationships in Thailand

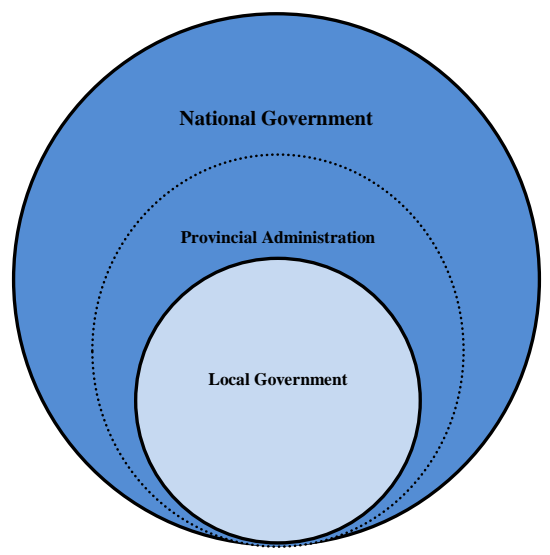

Source: Adapted from Wright's model of inclusive authority dependent hierarchy in Agranoff \& Radin 2014: p. 140.

The circle representing the Provincial Administration has an additional circle to identify the boundary and relation of provincial administration, which acts as the central government but is located in local areas. The model illustrated below is represented in the form of Thailand's administration structure, which is derived from the State Administration Act of 1991 and the Local Administration Act of 1914. The Act of 1991 promulgated the local authority as one of the state administrative branches (see Figure 
Figure 2.2 Thailand Administration Structure

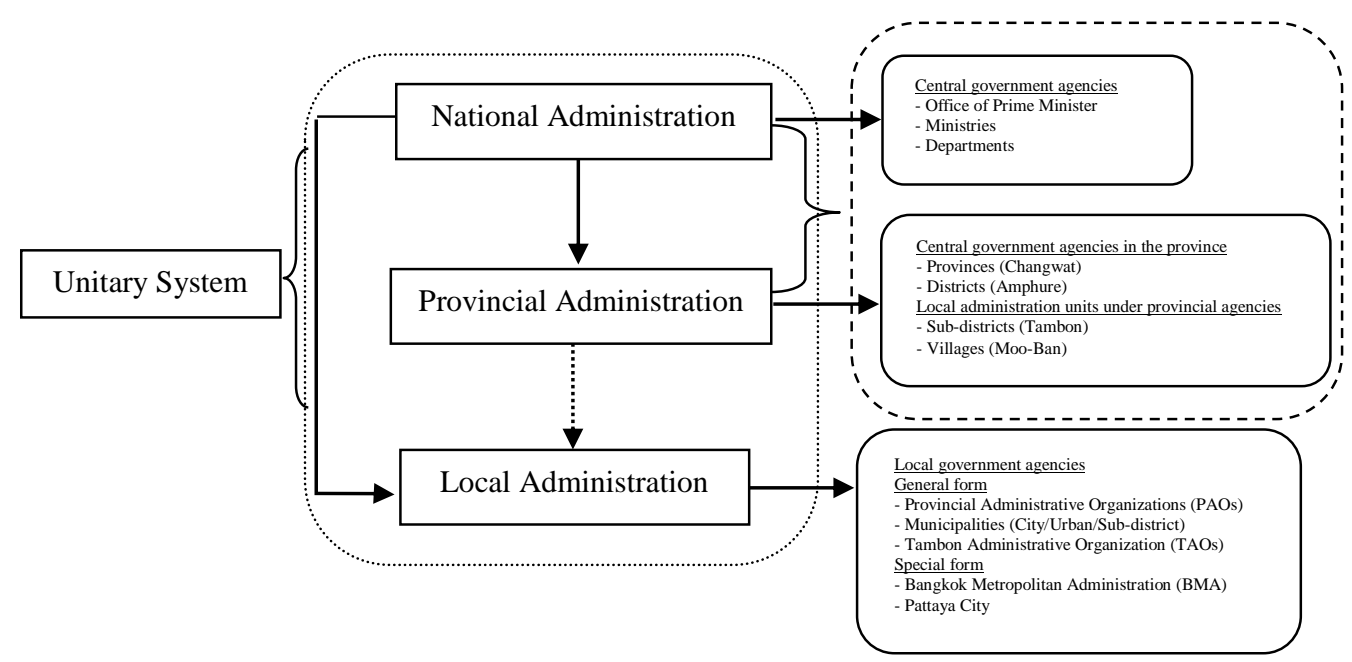

Source: Compiled by the researcher based on the State Administration Act of 1991, the Local Administration Act of 1914, and the Determining Plan and Process of Decentralization Act of 1999

The State Administration Act of 1991 provides for three administrative fields. At the top level, the national administration is comprised of the Office of the Prime Minister, and various ministries and departments. The national government agencies are mostly located in Bangkok and exercise their power primarily through the provincial administration, but also through local agencies. The policy processes and regulations are usually carried out at the provincial level (Mansrisuk, 2012; State Administration Act, 1991; United Nations, 2004)

The second level, provincial administration, is a branch of central government and the central ministry branches that are located in the local areas. However, those agencies are not part of the local government. The provincial administration exercises its power through the provincial governor and the chief executive officers of districts, who are 
appointed by the Ministry of Interior, a national ministry. In addition, there are two local administration units under the provincial administration. Those agencies are the subdistrict (Tambon) and the village (Moo-Ban). Even though the head of Tambon (Kamnan) and the headperson of village (Phu-Yai-Ban) are elected by the community residents, then they are approved and officially appointed and paid by the provincial administration. Though they work with the local governments, they are responsible to the provincial administration and, ultimately, the central government. Their duties include community leader, community security, conflict mediator, and central government representative in the community, whereas local governments provide public services (Mansrisuk, 2012; Nagai, Funatsu, \& Kagoya, 2008; State Administration Act, 1991).

At the lowest level, the local government is considered an administrative branch of the central government. It is a creature of the constitution, which values the democratic society and decentralization to subnational government. Thailand's local government has two forms. One is a general form that is composed of the Provincial Administration Organization (PAO), Municipality, and Tambon Administration Organization (TAO). Another is a special form that is comprised of Bangkok Metropolitan Administration and Pattaya City and only exists in those two jurisdictions (Determining Plan and Process of Decentralization Act, 1999; Mansrisuk, 2012; Nagai, Funatsu, \& Kagoya, 2008; State Administration Act, 1991). 


\section{Decentralization and Thailand Local Government System}

The decentralization provision in Thailand is a policy creation, which was provided in the Thai Constitution of 1997. It aims to delegate the authority and responsibilities of the central government to local government. In addition, it aims to enhance local community involvement in the policy decision-making process, political activity, citizen participation, and economic development (Constitution of the Kingdom of Thailand, 1997; Krueathep, 2004; Mansrisuk, 2012; Rondinelli, 1981). From a service delivery perspective, decentralization is beneficial for local citizens because public policy, public service delivery, and public welfare would be allocated into the locality to serve the differing needs of local residents (Rondinelli, 1981; Saito, 2011). From a democratic and political standpoint, it is an opportunity for citizens at the local level to participate in political activities and in public decision-making processes that occur in their communities (Rondinelli, 1981; Saito, 2011).

\section{Impact of Decentralization on Local Service Delivery}

To implement the decentralization provision, the legislature enacted the Determining Plan and Process of Decentralization Act of 1999. This act has defined the forms, types, and responsibilities of local government. This law has a significant impact on the authority transfer from central to local government - including political authority, administrative authority, and fiscal authority (Determining Plan and Process of Decentralization Act, 1999; Krueathep, 2004; Nagai, Funatsu, \& Kagoya, 2008). 


\section{Local Structure and Political Authority}

Local government in Thailand exists in two forms. First, the general form of local government is responsible for providing public services in most areas of the country and consists of PAO, municipality, and TAO. A second is a special form of local government is responsible for serving the special and strategic areas. Bangkok Metropolitan Administration provides the public services in the capital city area, as it is the government center, business center, and gateway to the country. In addition, Pattaya City serves the industrial and tourism area east of Bangkok (Krueathep, 2004). Figure 2.3 illustrates the local government structure as well as the intra-governmental relationship in Thailand.

Figure 2.3 Local Government Structure and Intergovernmental Relationship

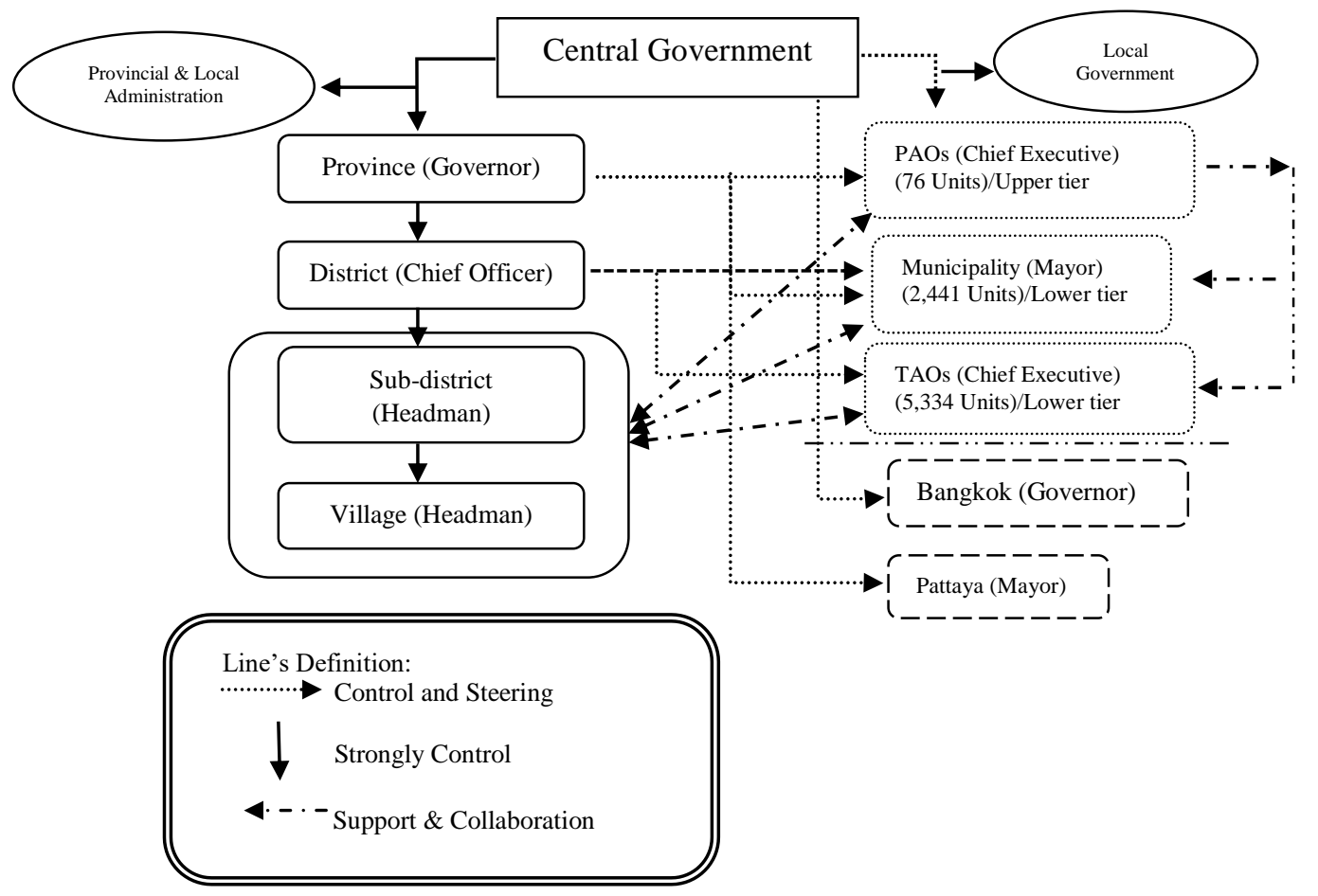


Source: Compiled by a researcher based on the Local Administration Act of 1914, the State Administration Act of 1991, the Determining Plan and Process of Decentralization Act of 1999, and the Image Model of Thai State Administration (Nagai \& Kagoya, 2011). The local government units are collected from local government data as of May 18, 2017. Link: http://www.dla.go.th/work/abt/index.jsp.

Local residents accept the political authority of the local government because they feel it provides education and strengthens the foundations of democracy at the local level. More importantly, moving government closer to citizens is the best way to improve government performance and to respond to the different needs in local communities.

Within this structure, Nagai and Kagoya (2011) explain that a characteristic of Thailand local administration is "the dual existence of various field agencies of central government and local government" (p. 138). This means that provinces and districts, as the branches of central government, remain the authorities for local governments and maintain control over various aspects of governance, such as annual budget approval, local planning, local administration, councilor removal, and so forth. In addition, we can view the relationship between local governments $(P A O$, Municipality, and TAO) and local administration units (Tambon and Mooban) as the parallel agencies within this structure (Nagai, Funatsu, \& Kagoya, 2008).

\section{Local Functional and Administrative Authority}

The Decentralization Act of 1999 has mandated the responsibility of providing public services to local government, which were previously operated by central 
government and provincial agencies, in six dimensions: (1) providing fundamental infrastructure; (2) developing and sustaining quality of life; (3) providing community security and preventing crime; (4) promoting local investment, trade, and tourism; (5) protecting and preserving the environment and natural resources; and (6) preserving and promoting local culture, tradition, and wisdom (Krueathep, 2004; Office of the Commission on Local Government Personnel Standards). ${ }^{2}$

This means that local government has discretion over local management and public service delivery based on the mandated duties stated in the Determining Plan and Process of Decentralization Act of 1999. In addition, each type of local government can recruit and hire the employees to serve in local government offices and public service tasks (Determining Plan and Process of Decentralization Act, 1999; Nagai, Funatsu, \& Kagoya, 2008).

\section{Local Discretion and Fiscal Authority}

After a decentralization law is enacted, a high degree of decision-making should occur at the local level (Krueathep, 2004; Rondinelli, 1981; Saito, 2011). The Thai Determining Plan and Process of Decentralization Act of 1999 devolves and transfers the decisions regarding fiscal authority to local government. As a result, local government can develop and enact local planning and regulations, especially the fiscal plan. In

\footnotetext{
${ }^{2}$ Source: Office of the Commission on Local Government Personnel Standards. Link: http://www.local.moi.go.th/webst/botfam1.htm
} 
addition, local government can collect fees for public services such as water, sewage, garbage, electricity, public transportation, document issuance fees, etc. According to the tax collection authority, local government can collect some local taxes, like property tax, sign tax, permit tax, and business tax (Determining Plan and Process of Decentralization Act, 1999; Nagai, Funatsu, \& Kagoya, 2008).

\section{Context of Thailand's Political Crises}

In Thai political history, most political crises initially arose from strains and struggles within elite groups and the military. Political crises have become normal events for Thai political society (Fry, 2014; McCargo, 2000). The current political crisis is more complicated and dynamic than most of those in the past. There are various groups involved in the political networks. As Uwanno (2011) mentioned, we can see these networks through the dynamics of Thai politics. He explained that there are four groups that influence each other within "dynamics of Thai politics" (Uwanno, 2011, p. 19). These four groups include: 1) the monarchy, 2) the military and bureaucrats, 3) middleincome people living in urban areas and having better market bargaining power and resource accessibility, and 4) people living in rural areas and having low negotiating power. They interact with each other and exercise power through these networks. These four groups are the vital mechanisms to influence both government formation and even government destruction (Uwanno, 2011). 
To illustrate the patterns of Thailand political crises, McCargo (2000) classifies the typology of Thai political crises from 1985 until 1997. This typology demonstrates the causes of political crises, for example, internal disagreement among groups within the military, people's dissatisfaction, political corruption, and economic collapse (McCargo, 2000). As observed, for recurrent political crises, those causes remain in existence and become more powerful.

\section{Thailand's Political Crises in Post-Democracy}

A political event that occurred in 1932 is considered a major turning-point of Thai politics. Even though the reform was bloodless, it caused a major change in the Thai political system. The absolute power initially held by the King was transferred to a government installed by the military and by the educated class. The form of political system was changed from an absolute monarchy to a constitutional monarchy, in which the King had less power in administrative and political roles. The King played a greater role as an institutional and ceremonial symbol under the Constitution of 1932 (McCargo, 2000).

In addition, the strong bureaucratic system and centralized state structure eroded the progress of democracy. Political crises were most often ended by using military power (Paribatra, 1993). Thai history shows that since 1932, Thailand has experienced 19 military coups (Brown, 2014), with 13 of them being successful (Chambers, 2015). The most recent coup d'état, carried out by General Prayut Chan-o-cha, occurred in 2014. 
Political conflict instigated this most recent coup d'état, when the military decided that a coup was the most appropriate choice to resolve the political crisis in that turbulent time (Fisher, 2014).

Over the course of history, Thailand's political crises caused changes to political society in different ways and marked many historical events in each era. For example, Black May, in 1992, was a political protest which occurred in Bangkok against the illegitimate military government ruled by General Suchinda Kraprayoon (Pineda, 2010). The impact of this political uprising led to popular reform in Thai politics that extensively involved the citizens and political sectors to project the future of the country by drafting a new Constitution in 1997. This Constitution has been called the Constitution of the People (Chambers, 2015; Keyes, 2015).

\section{Recurrence of Thailand's Political Crisis and the 2006 Military Coup}

Thailand, after the 1997 Constitution, seemed to enter into a period of peace and freedom. People actively engaged in political activities and freely exercised their basic rights. In the year 2001, the Thai Rak Thai (Thai Love Thai Party), led by Thaksin Shinawatra, won the national election. His populist policy attracted the voters who were mainly from his political base in north and northeastern Thailand, which, combined, are home to the largest percentage of the population in the country. He was able to accomplish much during his first administration (Blondel \& Thiébault, 2010; Chachavalpongpun, 2014; McCargo, 2002). 
Figure 2.4 Timeline of Thailand's National Political Crisis

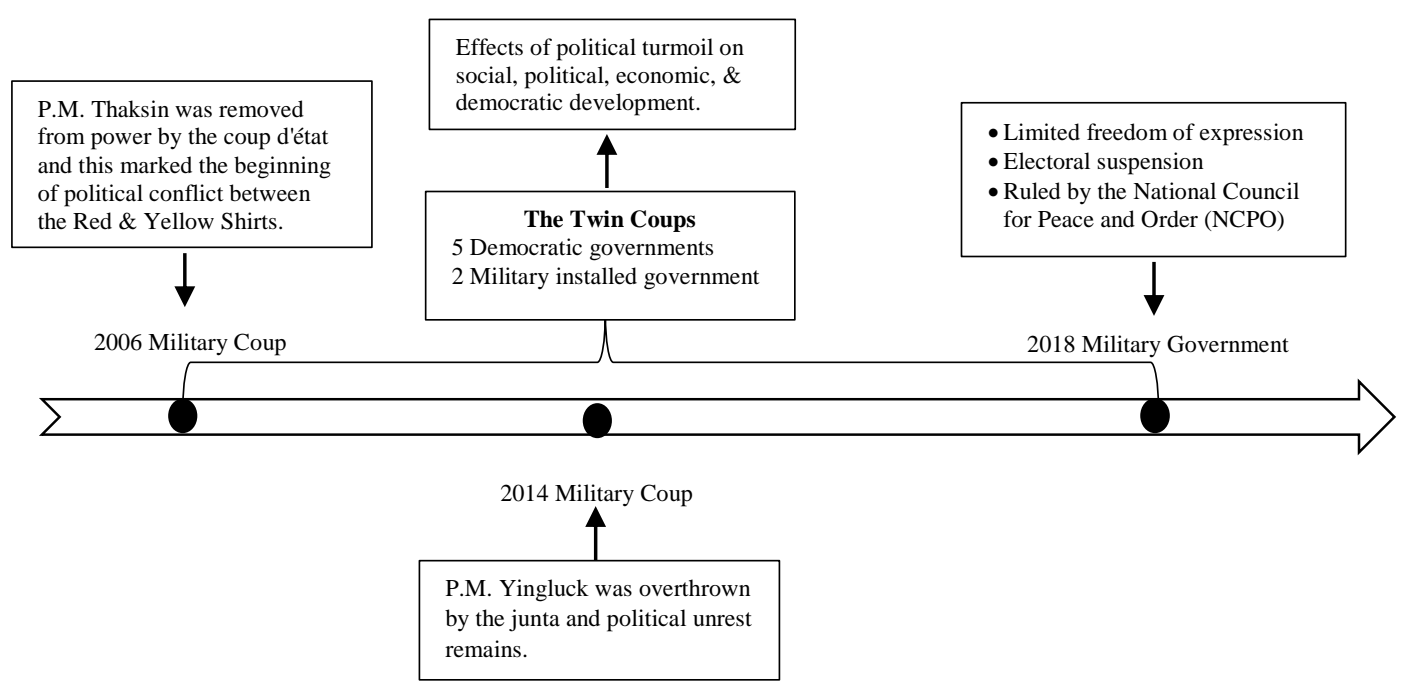

After the 2001 general election, which was a landslide victory for Thaksin, there was a short period of calm. In 2006, during the second term of his administration, another political crisis arose (depicted in Figure 2.4). The middle-class and elite groups, called "Anti-Thaksin" in Bangkok, became not only displeased but were frustrated with Thaksin's administration. After a short period of demonstration and protest instigated by the Yellow Shirt. His administration was toppled down by the military in 2006. He was prosecuted for corruption and conflict of interest with his populist policies. This political crisis not only affected economics, government stability, and public policy, but it also affected the unity of Thai society (Phongpaichit \& Baker, 2004; Pongsudhirak, 2008).

During this political crisis, people generally divided into two groups based on their political advocacy. The first group was the members of Thaksin's government who identified themselves as "Red Shirts." Most of them were geographically from northern 
and northeastern Thailand. Basically, these people have been seen as a grassroots group because of their rural origins and generally low income. The opposition group protested with the aim of removing Thaksin's government due to alleged corruption and the lack of effective governance. The anti-Shinawatra people were mostly from Bangkok and the urban areas. Many of them were from southern Thailand, which has been a large voter base for the Democrat Party. This group identified themselves as "Yellow Shirts." These two "colors" battled one another in major street protests. Sometimes the conflict was seen as a short-term political game, but repetitive political confrontation finally evolved into a prolonged national political crisis (BBC News, 2012; Bremmer, 2016; Prasirtsuk, 2010).

When crisis conditions lead to deadlock among groups, a military coup is seen as a conventional solution in Thailand, and this strategy was eventually employed (Baker \& Phongpaichit, 2014). On September 19, 2006, while Thaksin was attending a meeting at the United Nations in New York, the elected government of Thaksin Shinawatra was overthrown by the Thai military. The national political crisis became a threat to economic, social, and political development and had extensively affected central, provincial, and local government entities (Mydans \& Fuller, 2006; Ockey, 2007).

\section{Political Unrest and the 2014 Military Coup}

In July 2011, Yingluck Shinawatra, Thaksin's sister, accepted the nomination to run a political campaign for the position of prime minister. Eventually, her party, the Pheu Thai Party, won the national election and she became the first female prime 
minister of Thailand (Low, 2012). However, the anti-Thaksin group remained critical of her, calling her Thaksin's nominee. As they did before, leadership opposition came out in the streets and began to protest in Bangkok due to their dissatisfaction with her decisions relating to the Amnesty Bill, a bill that aimed to provide an amnesty for political offenses and political prisoners who were arrested and persecuted after the coup in 2006 (Marshall \& Szep, 2014).

Unfortunately for Yingluck, her administration was unable to hold power. Under the political pressure and with the development of a new political crisis, she decided to step down and call for a new election while her interim government remained in power. However, the election never happened because the opposition party and its protesters (Yellow Shirts) demonstrated to prevent it. The protest finally became more violent and out of control. As is common in Thailand, the conventional wisdom, a coup, was again used by the military (Jones, 2014).

In 2014, General Prayut Chan-o-cha led the coup d'état and called for national reform and the drafting of a new constitution. In addition, he was positioned by the junta to rule the country as the unelected prime minister. Currently, all junta-proposed national reform activities are still in process. The military government expects to complete the reforms within the given timeframe and will allow the general election in 2016, or a year 
after completion of a new Constitution ${ }^{3}$ (Associated Press, 2014; Crispin, 2016; Fuller, 2014).

The political situation is still controversial, especially the new constitution and the reform. Moreover, most of local government elected officials who ended their administrative term during this reform period were requested by the junta to continue serving in their positions until the central government finishes the reform mission (National Council for Peace and Order, 2014). Suffice to say, many things within the governmental structure could be affected due to political turbulence, even though the political unrest seems to be abating because the military government is still in power. So, crisis does not necessarily mean active political conflict but major unresolved constitutional issues and a factionalized regime. In reality, the political crisis remains just below the surface; it could emerge again any time after the military government steps down (Chachavalpongpun, 2014; French, 2016; \& International Crisis Group, 2014).

It is important to state that the military coups in 2006 and 2014, those that Baker (2016) called "the twin coups," "4 have had extensive effects not only at the national level, but they have also had a tremendous effect on economic, social, and democratic development throughout the country (Baker, 2016, p. 389; Pongsudhirak, 2014; Sethapramote, 2015; Yueh, 2014). During this period (2006 up to the completion of the

\footnotetext{
${ }^{3}$ As of the final review of this thesis (February 2018), this has not happened.

4 The author states that he called them "the twin coups" because the sources of these two coups were from the same groups of people and the same conditions. These two coups have a tight interrelation.
} 
research analysis in 2016), Thai society has suffered severely from the prolonged political crisis that caused economic downturn, decline of investment, political uncertainty and fears, etc.

To conceptualize the context of Thailand's political crisis, Table 2.1 integrates two frameworks that include the elements of crisis addressed by Boin, t'Hart, Stern, and Sundelius (2017) and the aspects of crisis provided by Krieger (2001). The first framework provides three elements of crisis; "threat, urgency, and uncertainty" (Boin, t'Hart, Stern, \& Sundelius, 2017, p. 5). As Boin, et al. (2017) explain, these three key elements help identify the different patterns of crisis. First, the threat helps us to perceive and locate position and space in which such a crisis occurs. Next, urgency helps identify the status of crisis. It helps us to evaluate the degree of severity that such crisis causes and the needs for responding. Finally, uncertainty triggers fears. Nevertheless, uncertain conditions help produce strategic measurements and management processes for crisis response.

The second framework has three components including "systemic crises, confrontation crises, and decision-making crises" (Krieger, 2001, p. 182). System refers to the whole structure that consists of socio-political interactions, norms, and regulations - institutions. Confrontation refers to the disputes that are caused from the challenges between two opposition parties. It may occur when the bargaining cannot reach common agreement. Finally, decision-making refers to the consequences of 
unsuccessful policy making processes that governments conduct. The results of these components cause problems for their citizens and for political stability (Krieger, 2001). The implications of the two frameworks develop the new, integrating framework for introducing the context of Thailand's political crisis. In Table 2.1, the framework explains how Thailand's political crisis matters and increases an understanding of context of Thailand's political crises.

Table 2.1 Theoretical Dimensions of Thailand's Political Crises

\begin{tabular}{|c|c|c|c|}
\hline & \multicolumn{1}{|c|}{ Threat to } & \multicolumn{1}{c|}{ Uncertainty about } & \multicolumn{1}{|c|}{ Urgency of } \\
\hline System & $\begin{array}{l}\text { - Threat of system } \\
\text { and institutional } \\
\text { collapse, loss of } \\
\text { capacity, and } \\
\text { weakness }\end{array}$ & $\begin{array}{l}\text { Uncertainty about } \\
\text { status, future, and } \\
\text { behavior of } \\
\text { institutions }\end{array}$ & $\begin{array}{l}\text { System/state is } \\
\text { KEY to political } \\
\text { stability and } \\
\text { development }\end{array}$ \\
\hline $\begin{array}{l}\text { Confront } \\
\text { ation }\end{array}$ & $\begin{array}{l}\text { Threat to political } \\
\text { consensus in army } \\
\text { elites, in society, } \\
\text { and in state society }\end{array}$ & $\bullet \begin{array}{l}\text { Fear of what other } \\
\text { side will do }\end{array}$ & $\begin{array}{l}\text { Danger of social } \\
\text { conflict that has } \\
\text { long term } \\
\text { consequences } \\
\text { (divided society) }+ \\
\text { longer it goes on } \\
\text { harder to fix }\end{array}$ \\
\hline $\begin{array}{l}\text { Decision } \\
\text { making }\end{array}$ & $\begin{array}{l}\text { Threat to ability of } \\
\text { government to make } \\
\text { decision on public } \\
\text { problems }\end{array}$ & $\begin{array}{l}\text { Uncertainty } \\
\text { whether decisions } \\
\text { government made, } \\
\text { when, how }\end{array}$ & $\begin{array}{l}\text { Public problems not } \\
\text { solved cause public } \\
\text { bad (e.g. garbage } \\
\text { not collected causes } \\
\text { disease) }\end{array}$ \\
\hline
\end{tabular}

To understand the context of Thailand's political crises, the framework provides three integrative explanations. Thailand's political crises since 2006 were obviously addressed through military interventions. The effects of these political crises triggered a system crisis, and the system crisis created threats to specific systems and institutions. For example, political shocks caused by military coups dynamically induced institutional 
turbulence and even collapse. The shocks also created threats to political and social systems. The government had administrative and political weaknesses. The government also lost the capacity to handle political instability and maintain policies. In addition, the system crisis created uncertainty about the status, future, and behavior of institutions. For example, citizens were uncertain about the status of the new constitution and future of a national election. The system crisis stimulated Thai society into realizing that threats caused by political crises are undesirable and dangerous to political stability and democracy. Political crises have to be addressed as an undermining factor to social and political development. Therefore, they need to be resolved as soon as possible. Political systems and civilian government should be the key to institute political stability and development (Boin, 't Hart, Stern, \& Sundelius, 2017; Krieger, 2001).

Second, Thailand's political crises are considered confrontation crises because sources for political crises were created by two conflicting parties-i.e. between government and an opposition party and between government and the military. Both sides were unsuccessful in negotiating within legislative means and failed to decide on a way forward. Consequently, this unresolved confrontation created a threat to consensus in army elites, in society, and in government. The confrontation between two political factions also created fear of what the other side would do. For instance, government feared large anti-government protests or of military reaction. Eventually, society experienced the threat created by the confrontations that triggered the danger of social conflict that has long-term consequences - e.g. divided society or violence. The longer a 
political crisis goes on, the harder it is to fix. Political crisis is an urgent agenda that needs every party to find a way out as soon as possible (Boin, 't Hart, Stern, \& Sundelius, 2017; Krieger, 2001).

Finally, the prolonged political crisis in Thailand is considered a decision-making crisis. Political crises create a threat to the ability of government to make decisions on public problems and to determine a way forward. These crises trigger an uncertainty about government decisions being made, when they are made, and how they are made. Government is uncertain about making decisions on social policies that may have a risk of non-compliance. The anti-government people and military elites closely watch policies and strategies that government decides to do. As a result, public problems are not solved properly. Those public problems then cause negative consequences-e.g. garbage is not collected, causing disease (Boin, 't Hart, Stern, \& Sundelius, 2017; Krieger, 2001).

\section{Literature Review}

\section{Studies on Effects of Political Crisis on Local Government Service Delivery}

To better understand the opportunities for this study, this section explores previous research on the effects of political crisis on local government service delivery. The previous studies in this area encompass two aspects: (1) the effects of political crisis on local government service delivery from international experiences; and (2) the effects of political crisis on local government service delivery in Thailand. 
The related literature on the effects of political crisis and how it has affected local public service delivery and socioeconomic factors is examined. The emphasis of previous studies centers on how the breakdown or decline of national political institutions and political leadership affects local government service delivery and socioeconomic factors. The first part presents research done in the global context, followed by a discussion of previous studies specific to Thailand.

After reviewing various sources, there appears to have been very little study done on the effects of political crisis on local government service delivery. Numerous studies emphasize how economic or financial crises negatively affected local governments (e.g. Carboni \& Milward, 2012; Greer, 2010; Nelson \& Balu, 2014; Reschovsky, 2004; Stenberge, 2011; United Cities and Local Government, 2009). However, only a few available studies look at the effects of political crisis on local government. Most studies were conducted in countries that were already experiencing fragile conditions, such as Somalia, Ukraine, and Zimbabwe. It is important to emphasize that the existing literature is insufficient to establish any working hypothesis but only useful to organize data collection into threats and opportunities and into the five moderating variables.

\section{Studies in the Global Context}

Regarding political institutions, Kynev (2006) investigated the effects of the 2004 national political and institutional crisis in Ukraine on "the system of local selfgovernment" (p. 32). After the regime change, the impact of institutional change affected local administrative systems; that is the local council members are elected by local 
citizens but local leaders are appointed and dismissed by the central authority. This change caused political monopoly controlled by central authority (Kynev, 2006). Importantly, Kynev (2006) stresses the importance that the 2004 political crisis in Ukraine developed a sustainable solution by strengthening "institutional mechanisms" because strong institutions help protect public interests from the intervention of a "monopoly of power by any single group" influenced by the central government (p. 37). Consequently, the stable institutions increase local authorities' capacity in providing services.

In the case of the political crisis in Zimbabwe, Musekiwa \& Chatiza (2015) note that "political polarization" tightened the relationship between national and local politicians because they were from the same political party, hence the local councilors were not interested in, or even ignored, public participation in local activities (p. 130). In addition, institutional breakdown caused policy interventions of central government on local authorities. Muchadenyika (2015) conducted research on the effects of "allocation of housing land between 2000 and 2012" on cities' service delivery in four major cities in Zimbabwe (p. 1219). The results revealed that prolonged political and institutional crisis in Zimbabwe created gaps for the central government's struggles to intervene in the operations of local authorities, for example housing services. Local authorities were limited and some local services were transferred back to a central authority and/or contracted out to the private sector (Muchadenyika, 2015). 
Regarding civic engagement, political crisis in Zimbabwe undermined civic engagement at the local level because political crisis caused "political polarization" that made a tight relationship between the national and local governments (Musekiwa \& Chatiza, 2015, p. 130). This may seem to be a positive effect, but actually it is not because national and local politicians are from the same party. They felt like they had enough stability to maintain political power, so the local politicians were not interested in building civic capacity and engagement in their local governments (Musekiwa \& Chatiza, 2015)

Moreover, during political crisis local residents tried to respond to the decline of local service capacity. Local citizens tried to help local authorities to provide services by setting up civic engagement mechanisms and affiliated organizations. Unfortunately, due to political circumstances, local authorities lacked capacity to handle the needs of citizens and low management capacity of citizen-led organizations (Musekiwa \& Chatiza, 2015).

Börzel and Risse (2016) argue that "weak or limited statehood or dysfunctional institutions does not necessarily lead to weak or bad governance," especially at the local level (p. 2). In addition, the research employed three kinds of trust (personalized-trust, group-based trust, and generalized-trust) as informal institutions to examine the existence of governance at the local level, although the status of the national political institution is weak and dysfunctional (Börzel \& Risse, 2016, p. 4).

In their research, Börzel \& Risse (2016) reported that "personalized trust within close-knit communities enables effective and legitimate governance at the local level in 
the absence of functioning state institutions" (Börzel \& Risse, 2016, p. 156). In addition, they argue that each kind of trust could support the other in order to maintain the degree of governance, especially when collective groups are strong and work across boundaries at the local level, even though national political institutions are in a dysfunctional phase (Börzel \& Risse, 2016).

For governance, Kynev (2006) states that the national political crisis triggered negative effects on the governance system and destabilized social unity of the country. Moreover, during the political crisis central government intervention undermined local transparency. Some local public services, such as housing services, were transferred from the local authority back to the national government, making it difficult for local councilors to exercise checks and balances or even be involved in management processes (Muchadenyika, 2015).

For political economy, political crisis in Somalia caused "state collapse" and “intractable conflicts" (Menkhaus, 2007, p. 357). Menkhaus (2007) states that the prolonged political crisis caused the civil war in the country. Due to the fighting, local communities were ruined and basic public services, such as hospitals, found it difficult to serve people. Citizens lived in poor conditions and lacked even basic sanitation, eventually causing disease and health problems within their communities (Menkhaus, 2007).

Musekiwa and Chatiza (2015) studied the relationship between the decline of local public service and the progress of citizen engagement during political turbulence in 
Zimbabwe. Due to the prolonged political instability, local authorities encountered financial deficits and lacked resources, which led to the decline of local basic service delivery.

In addition, Muchadenyika (2017) stressed that Zimbabwean national political breakdown created negative effects in both central and local service provisions. At the local level, municipalities were unable to provide and maintain basic public services such as roads, sewer, water, electricity, and housing, and also lacked the capacity to stimulate economic activities and employment (Munzwa \& Wellington, 2010, p. 139). Interestingly, Munzwa and Wellington (2010) emphasize that prolonged political crisis caused the decline of good governance, inducing "unemployment" and other hindrances to public service operations (p. 140).

Other studies done in the global context also reported negative effects of political crisis on local government public service delivery. Very few have shown a positive effect of dysfunctional state institutions on local governance. But Börzel and Risse (2015) and Musekiwa and Chatiza (2015) show that there are ways to have a "non-effect" via coping mechanisms at the local level, especially in civic engagement. Most cases obviously indicated the linkage between national political crisis and low capacity of local governments for providing basic public services. However, it is imperative to review the studies done in the Thai political context and address research opportunities for exploring the effects of national political crises on local government service delivery in Thailand. 


\section{Studies in the Thai Context}

After reviewing the recent Thailand-specific literature on political crisis and how it has affected local government service delivery, my observation is that available studies were primarily conducted more about the effect of economic crisis on government functions and civil society than the effects of political crisis on local service delivery. Nevertheless, these examples are important and useful for guiding research opportunities because political economy is the indirect way that national political crisis affects local government service delivery.

This section begins with the effects of economic crisis on public services and civil society. When the economic crisis in Thailand arose 1997, it widely affected public agencies, business sectors, and social policies. One study reveals that negative effects of economic crisis led to unemployment and wage cuts, poverty and inequality, and reduction in health services and educational opportunities (Jung et al., 2003, p. 97).

Similarly, there was a study examining the effects of economic crisis on the development of local government in Thailand. Khoman (2005) notes that even though economic crisis created negative effects at both the organizational and individual levels, "not all of its effects were negative" (Khoman, 2005, p. 58). The negative effects of economic crisis triggered financial deficits, decline of investment, layoffs, currency instability, and so forth. Surprisingly, the effects of the crisis also created an opportunity for government to work closely with citizens and strengthen the government-citizen 
relationship. This stimulated Thai government to become more "transparent and responsive to public concerns" (Khoman, 2005, p. 58).

This crisis triggered Thailand political reforms that included the progress of citizen empowerment and decentralization in Thailand (Khoman, 2005). This case illustrates that we can see that a crisis may help offset some of the negative effects it produces. While crises cause negative effects on the one hand, on the other they may produce some benefits.

As mentioned, previous studies about the effects of national political crisis on local government service delivery in Thailand are rare. In order to investigate "social and political dynamics" at the local level and integration of the concept of "coproduction and community empowerment," Sudhipongpracha and Wongpredee (2016) examined the effects of coproduction on community empowerment in two Thai municipalities (p. 3023). This research found that empowering local citizens to coproduce local services transformed them from "passive/reactive citizens waiting for government services and opportunity to voice their opinions to active/proactive citizens" (Sudhipongpracha \& Wongpredee, 2016, p. 311).

In addition, this research noted that even though the effects of "national political climate" may create threats for "citizens' political engagement" in the municipalities, some local activities, such as road maintenance projects, successfully engaged more citizens into coproducing processes than other local activities (Sudhipongpracha \& Wongpredee, 2016, p. 312). This is considered as an opportunity for local governments to 
maintain a local government-citizen relationship and strengthen civic engagement in local public service delivery. In addition, this research emphasizes that in "urban municipality," the degree of coproduction was moved from simply working together to co-management by creating an informal committee that included local political leaders, community leaders, citizens, and local officials (Sudhipongpracha \& Wongpredee, 2016, p. 313).

On threats, the literature presents how the economy has declined since the 2006 political crisis and how it has affected socioeconomic factors. Sussangkarn and Nikomborirak (2016) affirm that prolonged political crisis in Thailand obviously creates negative effects on the Thai economy as a whole. Political crisis induces uncertainty for both Thai and foreign investors to expand their investments in Thailand. Due to an unclear direction of the political situation, the export growth has been declining dramatically compared to times of stable political conditions. In addition, political turbulence and "declining competitiveness" labels Thailand as the "sick man" of the region (Sussangkarn \& Nikomborirak, 2016, p. 41). It is inevitable for local governments as public service providers to avoid these threats because a declining economy surely affects local revenues and discourages local investments.

Based on the data presented by the International Monetary Fund (IMF), since 2006 Thailand total investment (percentage of GDP) has been declining due to political instability (International Monetary Fund, Thailand World Economic Outlook Database, 2017; Sussangkarn \& Nikomborirak, 2016). 
The continuing political crisis since 2006 has undermined foreign and local investments. Manufacturers and investors lack confidence to invest and expand their businesses and especially to make capital investments. Instead, the investors prefer to increase their labor force rather than investing in machines; human labor being cheaper than machines in the short term. Additionally, labor forces are flexible to mobilize and demobilize when the situation is uncertain (International Monetary Fund, Thailand World Economic Outlook Database, 2017).

In summary, the literature reflects the effects of political crises that entail both opportunities and threats. Public service delivery is an important and a major responsibility of Thailand local governments. There continue to be concerns that the prolonged national political crisis in Thailand will affect public service delivery based at the local level. Many studies conducted in the global context reveal that political crisis creates negative effects on local affairs and basic public services operated by local authorities. In the Thai context, a few studies show how national political crises affected institutional breakdown, political participation, and add to a declining economy. Few of these studies spotlight specific intervening factors, for instance political institutions, citizenship, governance, political leadership, and economic factors that may affect local government service delivery. Addressing this gap is something that this current study will attempt to do.

This study explores how national political crisis, a fact of life, to some degree, since 2006, has affected local government service delivery in Khon Kaen Province, 
Thailand. The five moderating variables employed in this study are not used to formulate a hypothesis, but rather are used for looking at the antecedent conditions for local service delivery. The specific questions to be answered are: (1) whether local government service delivery experiences a negative impact, a positive impact, or some combination of the two; and (2) which moderating variables explain this. In order to guide the conceptual framework of this research, the following section addresses the relevant theories in political science and public administration.

\section{Theoretical Foundations}

While the intent of this study is not to test any hypotheses, it is necessary to use certain established theories to build a foundation for the analysis used in this study. There are three theoretical approaches that must be examined; institutional theory, governance theory (including civic engagement and public leadership), and political economy theory. Their theoretical implications for local government service delivery under political crises are also addressed. First, the discussion describes the broad concept of institutionalism and then concentrates on formal institutions and laws, and looks at the concept of decentralization. Next, governance theoretical approaches explain the core concepts of new public governance, civic engagement, and public leadership. Political economy theory is explored to provide an understanding of the institutional interrelation between politics and economics and explore how change in political institutions triggers change in economics or vice versa. Finally, how these three relevant theories are related to each other is studied and their implications for current research summarized. 


\section{Institutional Theory}

Defining Political Institutions. Institutional theory plays a vital role in political studies, economics, and governance studies. The essence of institutional theory provides the sophisticated framework to reflect public policy processes, behavior of individuals in political society, and impacts of changes within political institutions (North, 1990; Peters, 2011; Peters \& Pierre, 1998; Putnam, 1993). Scholars have presented approaches to study institutions using various assumptions. Nevertheless, they commonly agreed that the institutions do matter (Peters, 2011, p.79; Teske, 1991).

To understand the complicated patterns of institutions, North (1990) characterized institutions into two forms; formal constraints and informal constraints (p. 4). The constraints generally are created by individuals or groups in order to contour human interaction and narrow the choices. In addition, those constraints are the sources to form institutions. For example, the formal rules generally are developed from traditional and social norms or agreements. They are evolved and institutionalized due to the constraints and social complexities (North, 1990).

The patterns of formal institutions include constitutions, formal laws, political rules, economic rules, and contracts (North, 1990, p. 47). These formal institutions are created in order to guide and shape human interactions and behaviors, especially at the individual level. The impacts of formal institutions create the interrelations within institutions. For example, the formal political rules trigger economic compliances or vice versa. Typically, the formal institutions are officially written down and constituted 
through the legislative process such as constitutions and laws (Dobler, 2011; North, 1990).

For this research, I focus on the formal institutions, or what North (1990) called "formal constraints," because much of the informal institutions are considered as governance (p. 46). The formal institutions can help us understand whether change or instability in formal political institutions affect Thailand's local government service delivery performance or even social economics in times of national political crisis.

Theoretical Implications. The institutional theory helps guide the analysis in this study. Political institutions rest in an analytical framework as one of the moderating variables that are affected by national political crisis, so that the result may affect the effectiveness of local government service delivery (March \& Olsen, 1984; Peters, 2012). To examine whether political institutions impact local government service delivery, the institutional theory helps explain how changes in formal rules, systems, and procedurese.g. constitution, laws, elections, voting - at the national level influence citizens' interactions, individual behaviors, local political institutions, and civil society (March \& Olsen, 1984; North, 1990; Peters, 2012).

The literature on political institutions in Thailand generally shows that Thailand's political institutions influence the patterns of politics (i.e. policy making processes), the political structure (i.e. centralized structure and authority), and "bureaucratic autonomy" (Hicken \& Selway, 2012; Painter, 2004, p. 377). In recent decades, due to political instability, formal political institutions in Thailand such as constitutions, formal laws, and 
the electoral system are unstable and fragile, and are undermined by political unrest. The institutional formations and distortions are influenced by various actors such as bureaucrats, civil society, the military, and the judiciary. Prominently, the military and judiciary are the most influential actors in political institutional progress (Kuhonta \& Sinpeng, 2014; Ockey, 2009).

For example, Kuhonta and Sinpeng (2014) argue that political institutions in Thailand are designed and steered by not only the "usual suspects such as the military, but from unexpected actors, such as the judiciary and civil society” (p. 334). The prominent evidence shows that the military and constitutional courts are influential actors in changing political institutions by legitimizing the two military coups in 2006 and 2014 . Consequently, the constitutions and other formal laws, as formal political institutions, were changed or suspended. The new institutions were drafted and constituted by the same actors in order to serve their own political interests (Kuhonta \& Sinpeng, 2014).

A change in one influential political institution affects the function of other institutions, such as the suspension of the constitution affecting the electoral system and political parties (Dalpino, 2012; Waitoolkiata \& Chambers, 2015). In addition, Kuhonta and Sinpeng (2014) emphasize that the formation of Thailand's political institutions seemingly serves specific political interests of the military and political elites rather than protecting citizens' rights and promoting good governance. Further, Bureekul and Thananithichot (2012) argue that political institutional instability in Thailand reduces 
confidence among citizens and undermines social interactions. This becomes an obstacle to successful reconciliation.

To understand the influences and interrelation between institutions and local governing processes, the following section discusses governance theory, which includes governance, civic engagement, and political leadership.

\section{Governance Theory}

Defining Governance. The meaning of governance has been discussed widely across academia and in studies of modern government practices. Some scholars identify the meanings that help illustrate the core features of governance as a "new process of governing" (Rhodes, 1996, p. 623). Stoker (1998) defined governance as "the development of governing styles in which boundaries between and within public and private sectors have become blurred" (p. 17). In this sense, governance is not only utilized for the public sector, but also the private and voluntary sectors. For public sectors, the meaning of governance refers to the interdependence between roles of governments and societal sectors in providing public services. The traditional styles of governing, i.e. "bureaucratic hierarchy" and command and control, have been replaced by multi-jurisdictional collaboration, networks, and collective actions (Bevir, 2011; Rhodes, 2007; Stoker, 1998).

In the private sector, governance refers to the process of "corporate governance" that derives business concepts to apply to government practices and public service delivery (Rhodes, 1996, p. 654). The voluntary sector refers to governance as "self- 
governing networks" (Rhodes, 1996, p. 658). Self-governing organizations play a vital role in providing service delivery by replacing or supporting the works of government through societal networks and partnerships. The lifetime of a self-governing organization is short because it is easily influenced by interest-groups or potential members (Hirst, 2000).

Even though the definitions of governance are diverse based on levels of use and forms of institution, I conclude that governance and institutions are not equivalent terms. Rather, governance is about the values of collective actions and collaboration for common goals. In theory, excessive power of central government is restrained by individual citizens and civil society in pursuit of improving quality of public services, expanding policy networks, enhancing social equality, increasing transparency, and promoting accountability. To understand the evolution of the foundations of governance, the following section illustrates the development of governance theory, from a statecentered approach to a society-centered approach.

\section{Effect of the Evolution of Governance Theory on Public Service Delivery}

Governance is considered a new paradigm of public management that developed out of traditional public administration (Osborne, 2006). Due to social complexity and various needs of public service delivery, government is no longer a major policy actor and a main public service provider. Governments have to blur boundaries and connect to societal actors and professional service providers in order to cope with complicated services and improve the quality of public services (Klijn, 2002). Still, a new paradigm 
evolves by overlapping or interconnecting with existing paradigms. The shadow of hierarchy remains influential in the operation of traditional public administration and public management (Klijn, 2002; Osborne, 2006). The evolution emphasizes three main stages: public administration, new public management, and new public governance.

Public Administration. Traditional public administration sees government as a main actor in the process of governing, as well as policy processes. Economic and societal sectors are also steered by the central government (Denhardt \& Denhardt, 2003; Peters \& Pierre, 1998). Public service delivery and policy decision-making are controlled and dominated by the central government through the ministries (Hirst, 2000). As a central actor, government exercises power through formal institutional procedures. Meanwhile, subnational governments and societal sectors are controlled through hierarchical structures (Renn, Klinke, \& Asselt, 2011; Stoker, 1998). In addition, “public institutions offer one-size-fits-all services" to citizens and societal sectors (Osborne \& Gaebler, 1993, p. 168). As mentioned, the hierarchy is a governance mechanism that is used within governmental administration (Osborne, 2006, p. 383). Also, bureaucracy plays a dominant role in policy decision-making processes and policy implementation (Osborne, 1993; Osborne, 2006). The public administrative systems are designed and directed by bureaucratic concepts in order to facilitate public administrators and civil servants rather than citizens and society (Osborne, 1993; Osborne \& Gaebler, 1993).

When society is more complex and traditional public service provisions are challenged by diverse needs and expectations of civil society, government no longer has 
as large a role in service delivery and public problem-solving (Renn, Klinke, \& Asselt, 2011). Plus, when government encounters fiscal hardship for expanding public services and even lacks budget to subsidize subnational governments such as states and local governments, most public services are transferred to local governments without funding (Osborne, 1993). These factors push government to change administrative approaches in order to improve their performance (Osborne, 1993). In order to deal with these challenges and also improve government performance, government employs business administrative approaches in public organizations in pursuit of enhancing efficiency and effectiveness of public services (Denhardt \& Denhardt, 2003). The poor performance of bureaucracies and old administrative techniques are increasingly criticized and attacked by the public, and eventually the old public administration is transformed to new public management (Denhardt \& Denhardt, 2003; Osborne \& Gaebler, 1993).

New Public Management. New public management (NPM) is developed based on "managerialism" that values privatization and business administrative approaches as the core of governing process in the public sector (Rhodes, 1996, p. 655). Government employs the successful concepts of business administration and market-based strategies to improve public service provision (Peters \& Pierre, 1998). The constraints and poor performance of traditional public administration put pressure on governments to expand networks and horizontally coordinate with other sectors to provide services (Rhodes, 2007). In addition, most government-led programs depend on "market mechanisms" and focus on the outputs rather than procedures (Denhardt \& Denhardt, 2003, p.13 \& Hood, 
1991, p. 4). NPM emphasizes customer-centric and performance-based management. Public-private partnerships encourage out-sourcing activities that help reduce public investment and improve the quality of service delivery. To accommodate this process, the government devolves authority and service provision to quasi-public organizations and the private sector (Denhardt \& Denhardt, 2003; Heinrich, 2011). More importantly, political leadership is one of the key success factors for achieving NPM because public leaders need to have "political entrepreneurship" in order to coordinate with both public and private networks (Peters \& Pierre, 1998, p. 227).

Even though NPM is asserted to be a reconnecting mechanism between theory and practice (Frederickson et al., 2012), NPM is still criticized by many public administration scholars. As Osborne (2006) stressed, NPM is merely a transitory stage, which transforms public administration to new public governance. Government uses NPM as an instrument to merely maintain intra-public organizational performance rather than being of public value (Osborne, 2006; Rhodes, 1996).

Even though most public services are devolved to other public organizations and even the private sector, the shadow of public institutions, e.g. bureaucracy and hierarchy, remain influential because the government wants to ensure that public services are fairly and efficiently distributed (Moe, 1984). In addition, to be successful, government management has to understand and implement monitoring and measuring processes for those service provisions that have been contracted to the private sector. Some contracted activities may result in poor performance or may not respond to the needs of society. 
Additionally, management failures can cause problems to government (Hefetz \& Warner, 2004; Moe, 1984). Moreover, some are concerned that NPM may create a channel for the private sector to take advantage of public service provisions rather than provide "cheaper and better services for all” (Hood, 1991, p. 9).

The call for more collective action and societal collaboration prompts governments and society to shift orthodox and business administrative approaches to new public governance that values social interaction and networks. The sense of customer service in NPM is shifted to the sense of serving citizens in new processes of governing (Denhardt \& Denhardt, 2003). Due to theoretical and practical transition, new public governance emerges as a new process of governing in the public sector (Kickert, 1997; Rhodes, 2007).

New Public Governance. New public governance (NPG or "governance") is a recent administrative concept of government that challenges, and even replaces, the limitations of traditional public administration and state-centered approaches (Rhodes, 2007; Stoker, 1998). NPG values collective action and network-based management. Government mutually shares power, authority, and resources with "multi-actor networks," especially in public policy—i.e. policy network, and public service provisions (Enroth, 2011; Peters \& Pierre, 1998; Renn, Klinke, \& Asselt, 2011, p. 233).

In this new process of governing, government changes its role from one single actor to having multiple interactions with societal sectors from both public and nonpublic sectors that have diverse roles, levels, and institutional settings. More specifically, 
these governance networks are dynamic and work across boundaries (Renn, Klinke, \& Asselt, 2011). Peters and Pierre (1998) stated that new public governance helps enhance policy engagement, public-private partnerships, and voluntarism in public service provisions. Governmental structure is less hierarchical and a top-down administrative approach is replaced by a bottom-up approach (Kickert, 1997).

In addition, new public governance influences the features of institutions because the new process of governing induces dynamic and collective patterns of human interactions and behavior. The actors within collective interactions are more diverse in terms of goals, needs, and interests, so that institutions are more adaptive and flexible to a dynamic society. More specifically, the interactions link not only the actors within institutions, but also those from outside. New public governance emphasizes coordination and networks across boundaries (Peters, 2011).

\section{Collaboration}

The new governance approach creates new procedures and opportunities for the public sector to flexibly collaborate with various actors and networks across boundaries. To pursue effective collaboration in public service delivery, governance stimulates active interactions among actors through collaborative decision-making processes in order to enhance effective policy engagement and achieve collective goals (Bevir, 2011). Additionally, institutional design and formal rules are important factors to help the progress of collaborations because the scope of collaboration is bounded not only by the public sector, but also the private and non-profit sectors (Bingham, 2011). The following 
section addresses the key definitions of collaboration as theoretical and practical dimensions in governance perspective and then discusses the features and impacts of collaboration on public service delivery.

Defining Collaboration. From a governance perspective, collaboration refers to interactions among collective actors as partners from both inside public organizations and "outside a single organization" in order to reach an achievement of policy objectives and public service delivery (Bingham, 2011, p. 386). Bevir (2006) underscored that collaboration is a new governing approach that is a consequence of the change from "laws and commands to negotiation and diplomacy" and from "a monolithic bureaucratic hierarchy toward multilevel institutions" (p. $426 \& 434)$. Collaboration occurs when the actors interplay and exchange skills and resources across organizations in order find better solutions and innovations. Collaboration stimulates public engagement in policy discretion and administration. The stakeholders who are involved in collaborating processes are from different facets of civil society, for example, the public sector, the private sector, and non-profit organizations (Bevir, 2006; Bingham, 2011; Emerson, Nabatchi, \& Balogh, 2012). To truly understand the importance and impact of collaboration on public service delivery, we must examine the forms of collaboration that occur between various sectors (Bingham, 2011).

Collaboration among Multiple Sectors. Collaboration is an important governing mechanism to improve effectiveness of public service provisions. Government no longer acts alone in service delivery due to lack of capacity and resources, hierarchical barriers, 
and ineffective bureaucratic instruments (Bingham, 2011; Sirianni, 2009). Collaboration creates space for linking strategic partners from multiple sectors and different institutional settings to work together in partnerships (Bevir, 2006).

To understand the distinctive features of collaborative partnerships, Mackintosh (1992) presented three models of partnership as mechanism to develop effective collaboration; "synergy," "transformation," and "budget enlargement" (p. 213). Even though the model is developed to explain public-private collaborative partnerships, the implications of this model are useful for today's collaborative governance. The synergy model emphasizes collaboration among diverse stakeholders across boundaries by sharing and exchanging skills, resources, and goals in pursuit of gaining mutual benefits and producing innovations (Mackintosh, 1992, p. 213; Pollitt, 2003). Additionally, Tschirhart, Amezcua, and Anker (2009) suggested that resource sharing is important for effective collaboration. Nevertheless, public managers should be concerned about "functionality," that those resources can be utilized effectively (p. 17). Resource sharing should be viewed as an important factor for achieving organizational purposes. Tangible resources provide a source for estimating an availability of resources before sharing them with other partners (Tschirhart, Amezcua, \& Anker, 2009).

Secondly, the transformation model offers mutual opportunities for both public and private sectors to exchange or adapt values and practices between one another as a “joint venture” partnership (Mackintosh, 1992, p. 216). The public sector can take this opportunity to encourage the private sector to better understand public value and public 
interest. Conversely, the private sector should also try to transfer useful practices and successful experiences to the public sector so that these lessons help encourage the public sector to perform efficiently and accountably (Mackintosh, 1992).

Finally, the budget enlargement model is a strategic approach for collaborative partnership that is used for gaining financial support from a third party, such as central government (Mackintosh, 1992, p. 217). In this sense, the public sector lacks the budget to operate public services or infrastructure programs, while the private sector is concerned about failures and risks. In order to minimize risks and increase financial feasibility, these two parties seek to build common agreements and collaborative partnerships in order to be in a better position to request financial subsidies from central or local governments (Mackintosh, 1992). Pollitt (2003) argues that joined-up government, or what Mackintosh (1992) called joint venture, is not a one-size-fits-all approach. The public sector should carefully employ a joint approach to use for certain types of projects based on contexts and conditions because the effective collaboration relies on these contextual factors and appropriations (Connick \& Innes, 2003; Gray, Jenkins, \& Leeuw, 2003).

For collaboration among multi-sectors, Ansell and Gash (2008) argue that this form of collaboration is considered an informal collaboration. It is developed based on a conventional approach that emphasizes an achievement of partnership through informal connections between the public sector and interest-groups rather than collective decisionmaking and public agreement. In contrast, formal collaboration refers to collaborations 
that focus on building public consensus among the various stakeholders, i.e. citizens, public sector, private sector, non-profit sector. These are facilitated through the "formal forum"-e.g. town hall meetings, council meetings, etc. (Ansell \& Gash, 2008, p. 547). The literature on governance in Thailand generally shows that initially government played the role as the main actor in the public sphere. The centralized bureaucratic system and hierarchical structure influenced policy processes and public service delivery. National government and ministries in Bangkok were the actual powerholders in public administration (Painter, 2004; Wongpredee \& Sudhipongpracha, 2014). Later, government was faced with economic and political constraints. These challenging factors pressed Thai government to improve administrative performance to increase the efficiency and effectiveness of public service. Most of the public services were transformed to quasi-organizations or even to the private sector in order to enhance collaborative governance and quality of public service (Bowornwathana, 2000; Painter, 2004).

In addition, Thailand political reform triggered a new pattern of governing process that valued the role of the citizen, self-governance, transparency, and accountability. The decentralized governing process (written in the 1997 Constitution) was adopted as a mechanism to improve public services, enhance local self-governance, and stimulate citizen participation (Bowornwathana, $2000 \&$ Sudhipongpracha, 2016). Nevertheless, Thailand's national government remains an influential actor in resource 
allocation and political power, impeding the progress of governance and decentralization (Marks \& Lebel, 2016; Sudhipongpracha \& Wongpredee, 2015).

\section{Civic Engagement}

As a result of the decompressed nature of authority in the governance framework, civic engagement and public leadership have emerged as important and related frameworks of research.

Governance creates new patterns and chances for engaging citizenry in public policy processes and public service provision (McLaverty, 2011). Civic engagement becomes a vital element of new political and governing processes that value the role of citizens as primary participants in designing policy and public service. Civic engagement also generates positive impacts on democracy and the public policy process (Michels \& Graaf, 2010; Holmes, 2011). In addition, some scholars emphasize that the life of public service agency and civic community are shaped by active citizen participation in order to develop effective public service and progress community value (Putnam, 1993; Adler \& Goggin, 2005).

The characteristics and practice of civic engagement can be seen in various ways, depending on the organizational and institutional settings. Furthermore, it can be different in terms of public or private entities (Holmes, 2011). To understand the meaning of civic engagement, scholars define civic engagement in various ways depending on the purposes and aspects of engagement activity (Adler \& Goggin, 2005). The following 
section discusses the definition of civic engagement theory and theoretical implications of civic engagement on this current study.

Defining Civic Engagement. To narrow down the specific definition of civic engagement, Putnam (1993) defines civic engagement as when "citizens in civic community devote and share their interests by performing active public participation in public affairs" (p. 87). Citizens in civic community should abandon the sense of selfinterest and increase the value of mutual interests. To be citizens in civic community, it is not necessary for obligating every citizen to remove self-interest or hold to selflessness. However, citizens should not use their self-interest to advantage over the interests of other citizens. The sense of self-interest should be preserved for protecting personal rights rather than harming the rights or interests of others (Putnam, 1993). The benefit sharing within civic community is a useful definition of civic engagement. Public space should be open to every citizen to engage in public activity, no matter who they are, where they are from, or to what political party they adhere. Eventually, the public interests gained from civic engagement will benefit every citizen and citizen group within civic society.

Spectrum of Public Participation. To classify the level of public participation in public service delivery and also in civil society, the International Association for Public Participation $\left(\mathrm{IAP}^{2}\right)$ provides a spectrum of participation in order to identify the roles of the public sector in public participation processes. There are five levels within the spectrum, and each level indicates an "increasing impact on the decision" (IAP 2 , 2014). 
The first level of public participation is to inform the public about basic objectives; information that helps them to comprehend the background of issues and proposed solutions. The second level is to consult citizens to gain their input, e.g., options, opinions, and proposals. The third level is to involve the public in working sessions. This creates an opportunity for the public sector to work closely with citizens. The fourth level is to collaborate with the public for developing tools for the decision-making process. The fifth level is to empower discretional authority for the public to finalize the choices that meet their needs $\left(\mathrm{IAP}^{2}, 2014\right)$.

The literature on civic engagement in Thailand generally shows that citizen participation is more recognized and influential over public and political decision-making processes since the 1997 Constitution was promulgated. Bringing citizen participation into the Thai Constitution was inspired by the participatory democratic era (Bowornwathana, 2000; Krueathep, 2004; Munger, 2007). For example, Bureekul (2009) argues that the formation of Thai political institutions since the 1997 People's Constitution valued citizen engagement as a foundation of participatory democracy. This institutional reform enhanced the roles of citizens in policy making processes, political processes, and legal processes at both the national and local levels. Specifically, at the local level, Bureekul (2009) emphasizes that Thai citizens engage in policy and political processes from beginning to end as well as exercising their roles in the process of checks and balances (i.e. informing, consulting, deciding, checking, and removing). 
In recent decades, citizen engagement in public and political activities has progressed dramatically because citizens understand and realize the importance of their roles in policy and politics. Nevertheless, in certain political contexts, it seems like the bureaucrats and the political power-holders remained reluctant to welcome citizen engagement because engaging citizens in public activities paves the way for [potentially unwanted] government transparency and accountability (Bureekul, 2009). In some local communities, citizens engage more in interactive and co-productive activities in their communities because they have a channel to express their voices and work together with other local residents and local leaders (Mutebi, 2006; Sudhipongpracha \& Wongpredee, 2016).

In conclusion, it is important to stress that civic engagement is an important factor to increase trust and transparency in government. Citizens have confidence in their government because they are involved in every process of decision-making. Having high transparency in public organizations triggers better governance and legitimacy. Also, eventually it helps improve public services and government performance (OECD, n.d., para.1).

\section{Public Leadership}

Leadership is an important mechanism for achieving the process of governing in organizations, whether in the public or private sectors. In organizational administration, competent leadership helps enhance quality and efficiency of public services (Wart, 2003). In new governance regime, leadership is a driver for furthering new public 
governance that values collaboration across levels and sectors. Effective leadership in collaborative governance requires the capacity to create civic engagement, promote motivation, and initiate mutual partnerships (Emerson, Nabatchi, \& Balogh, 2012). In public governance today, leadership encounters many challenges that are generated from both internal and external events. These factors trigger changes in terms of senses and features of leadership, especially leadership in public organizations, in order to respond to complicated social problems and uncertainties in society (Denhardt \& Denhardt, 2011; Wart, 2003). This study investigates political leadership in local governments as a moderating factor in public service delivery performance. To understand the meanings and various patterns of leadership, the following section provides key definitions in, and the relevance of, leadership theory.

Defining Leadership. The meanings of leadership are diverse and are based on practices and contexts. To ascertain definitions of leadership in the context of public organizations, scholars provide five meanings of leadership in administrative circumstances. First, leadership refers to the processes of generating results mandated by formal institutions and organizational structure. The administrative processes are completed based upon effectiveness, efficiency, and compliance. This type of leadership is applicable for frontline public administrators who perform their duties while maintaining political accountability. Second, leadership refers to supporting and improving processes that facilitate frontline officers who provide services. Next, leadership refers to capacity of executives to control and maintain an organizational 
alignment with the changes and the stresses of external and internal circumstances.

Fourth, leadership varies based on specific roles and services that public administrators are responsible for. Finally, leadership refers to the capacity of public leaders in providing vision and unitizing skills for making decisions on public service provisions, especially in difficult situations (Fiedler, 1996; Wart, 2003).

As can be seen, these meanings of leadership vary based on the contexts and institutions in which the leaders are involved. In modern organizations, leadership can be described through processes that allow people to use their competencies for solving problems, collaborating with other organizations or networks, and responding to public issues (Bao et al., 2012). It is essential that modern public service organizations, such as local governments, should have this kind of a leader. The following section explains the importance of leadership theory in public service, especially in times of crisis. To understand the related leadership theories, I discuss contingency leadership and leadership in crisis management.

Contingency Leadership. Contingency theory in leadership explains how leadership styles differ and relate to specific contexts or situations. Northhouse (2013) states that contingent leaders should be able to perform effectively when their leadership styles are suitable to those situations or conditions. The contingency leadership theory consists of two dimensions of leadership. The first dimension explains styles of leadership, which include "task motivated" and "relationship motivated" (Northhouse, 2013, p. 123). Leaders with a task-motivated style likely aim to achieve goals, while 
those with a relationship-motivated style primarily concentrate on building relationships among individuals and groups in organizations as mechanisms to achieve that goal (Fiedler, 1971; Northhouse, 2013). The second dimension of contingency leadership depends on three situational factors, which include leader-member relations, task structure, and position power (Fiedler, 1971, p. 129; Northhouse, 2013).

According to Fiedler's classical contingency model, leader-member relations are evaluated based on the degree of confidence and faith of followers on their leaders in such situations. Task structure is considered based on how well-organized the structure is. The degree of leadership is highly acceptable when people feel comfortable with clear directions. Position power explains a clear and strong relationship between positions and power. This means that leaders should have executive power and decision-making power in organizational administration (Fiedler, 1971). The current study employs contingency leadership framework to investigate how leadership operates as a mechanism to affect local service delivery performance in times of political crisis.

Leadership and Public Service. The concepts of leadership in new public service have widely discussed the ways that patterns of leadership in the new governance era should be in collaborative form, adaptive form, ethical concentration, and engaging form (Denhardt \& Denhardt, 2011). These new forms present a new objective of leadership that is shifted from a traditional pattern, which emphasizes leaders at individual level, power structure, formal authority, and steering (Denhardt \& Denhardt, 2003; Denhardt \& Denhardt, 2011). The new patterns of leadership in new public service, rather, emphasize 
values in society, citizenship, empowerment, and collective actions where the public organizations share these mechanisms with their citizens (Denhardt \& Denhardt, 2003).

Similarly, Frederickson (1996) describes how the pattern of leadership in new public administration is concerned with the effectiveness of public service professionals and a fairness of public policy implementation. In addition, a new form of leadership is proposed as a catalytic factor to achieve collaboration across sectors (Bryson, Crosby, \& Stone, 2006). In the current study, the concept of leadership in new public service is employed to help explain how local government leaders and public service professionals effectively provide and maintain public service delivery in times of national political crisis.

Crisis Management Leadership. In crisis situations, the critical tasks that public leadership needs to respond to are to reduce the effects of the crisis and to bring the situation back to normal (Boin et al., 2017). In order to guide the effective and appropriate ways that public leadership should employ when faced with a crisis, Boin et al. (2017) propose five critical tasks for strategic crisis leadership; sense making, decision making and coordinating, meaning making, accounting, and learning (p. 15).

To understand each critical task for strategic leadership, Boin et al. (2017) describe that, for sense making, strategic crisis leadership should have a sense of predictability by harvesting information, estimating causes and effects, and understanding the situation. Once a crisis occurs, they can measure and select an appropriate tool to strategically detect or minimize the effects of the crisis. 
In addition, making decisions and maintaining coordination in a crisis situation is difficult because crises are not routine events. Strategic crisis leadership should have thoughtful decision-making and careful responses. Gathering ideas and coordinating with various groups and various levels of social and governmental sectors helps increase leadership capability to cope with a crisis (Boin et al., 2017).

In a crisis situation, making sense of the situation is also necessary for strategic crisis leadership. Public leaders should take immediate action to minimize the effects of the crisis. Before doing that, public leaders should carefully consider details and define the components of the situation. This task guides leaders to deal with a crisis in an appropriate way and also increases credibility to the public (Boin et al., 2017).

Being accountable to the public is imperative for creating leadership trust because crises may cause public uncertainties. Sometimes, citizens lack understanding and gain insufficient explanation from public organizations. Therefore, it is important to give them the reasons for the situation, share what is going on, and advise them what to do next (Boin et al, 2017).

Lastly, a crisis situation is not always a bad thing. It creates an opportunity for learning. This type of learning triggers experiences and lessons for future strategy. Strategic crisis leadership learns from the past in order to build a better system for the future. This learning helps strengthen not only leadership capacity, but also produces inputs for forming policy and developing formal institutions (Boin et al, 2017). 
The literature on public leadership in Thailand generally shows that leadership in public organizations focuses on the leader at the individual level and the leader within power structure. For example, Charoensiri, Getsuwan, and Girdwichai (2016) argue that leaders in public organizations in Thailand, especially in local government, are highly competent to create a vision and respond to the needs of local residents. Because they also live in the community, leaders tend to listen to the voices of citizens and react to this input in order to solve problems. In addition, these leaders' characteristics can help enhance civic participation among local residents and encourage them to work together in local government activities. This becomes a source for building new patterns of public leadership that are derived from collective actions. Nevertheless, political institutional circumstances and centralized resource allocation influence the progress of public leadership at the local level. For example, local governments have to count on the fiscal transfer from the national government, so this central influence can also impede the development of local public leadership.

Further, Charoensiri, Getsuwan, and Girdwichai (2016) stress that external social and political conditions in each community are diverse. Hence, local governments need leaders who can see the contingencies and contexts and who can foresee and prepare for rapidly-changing situations. Moreover, Krueathep (2004) argues that local leaders who have business experience can create innovative administration for local government. However, this leadership characteristic may not succeed in every context because leaders with business backgrounds might use business tools in a negative way in order to further 
their personal interests. Local governments may also have leaders who have competency to build networks with business sectors.

\section{Political Economy}

The concept of political economy provides an understanding of the institutional interrelation between politics and economics. In addition, the political economy describes the impacts of political and economic institutions on economic performance (North, 1994). The concept of political economy also helps us to understand the factors or incentives that stimulate government to react to serve their citizens (Besley \& Burgess, 2002). The following section presents the definition of political economy and describes the relation between political economy and public service delivery. Also, the contribution of the theory to this research will be discussed.

Defining Political Economy. Political science and economic scholars have various definitions of political economy (Wamsley \& Zald, 1973). Buchanan (1964) stated that the concept of political economy originated in The Wealth of Nations, a classic work of renowned economist Adam Smith. The original "political economy" in this work refers to the circumstances of production where the fruits of the laborers' work produced wealth for the industrial barons. Importantly, the definition and characteristics of political economy are described through the patterns of human activity that eventually trigger the formation of institutions, for instance, laws and regulations (Buchanan, 1964).

Wamsley and Zald (1973) write that political economy is the relationship of government to the economy that stimulates a "competitive marketplace" and promotes 
efficiency of resource allocation and production (p. 64). In a public policy and public welfare perspective, political economy means policy options that efficiently benefit the public at large (Wamsley \& Zald, 1973). Hence, politics and economics influence each other through interacting processes. Once one variable becomes turbulent, it could have an effect the other as inter-dependencies between polity and economy occur (Arndt, 1983). To illustrate the components of political economy, the following section will describe the dimensions of political economy that include internal and external political economy.

Dimensions of Political Economy. The political economy can be illustrated in two dimensions. First, the internal political economy consists of internal mechanisms of economy—structure and processes of economy and norms of efficiency, and internal mechanisms of polity—-socio-political structure, political processes, leadership, and political institutions (Stern \& Reve, 1980; Wamsley \& Zald, 1973).

Second, the external political economy includes the external mechanisms of the economy-economic conditions and competitiveness, and the external mechanisms of polity-political conditions, influences of external actors, inter-organizational interactions, and distribution of power (Arndt, 1983; Stern \& Reve, 1980; Wamsley \& Zald, 1973). Importantly, some factors such as proximity, capacity, differentiation, concentration, and turbulence can be the environmental variables on the interactive relationship between internal and external political economy (Arndt, 1983; Stern \& Reve, 1980). 
For political economy analytical strategy, Stern and Reve (1980) suggested that the interactions between economy and polity are very important for an analysis of political economy. So that economy and politics should not be separated from each other in this analysis, this study employs the concept of political economy to investigate whether politics and economics are the determinant factors of local public service performance. The study also examines the interactions between national political conditions and economic distribution at the local level during the prolonged national political crisis in Thailand since 2006.

The literature on political economy in Thailand generally shows that Thailand's economy is shaped by political institutions. The interaction between politics and economics impacts policy success or failure at both the national and local levels. Notably, Thailand's political economy can be observed through the process of decentralization, especially fiscal decentralization, as Oates (1999) mentions in his essay on fiscal federalism. In the case of Thailand, one of the purposes of the decentralization was to promote local economy. In fact, fiscal decentralization remains limited and controlled by the central government. Due to this constraint, it creates fiscal inequality in some local governments and it also discourages local governments to improve the local economy (Kamnuansilpa, Wongthanavasu, \& Ando, 2013; Krueathep, 2004).

For example, Wongpredee and Sudhipongpracha (2014) argue that the formula used to calculate the budget allocation from the national government favors those local governments that have high capacity in revenue collection over those with a poorer base. 
Equitable budget allocation systems should prioritize the local governments with poor financial capacity to solve their budget imbalances. Importantly, local budget allocation processes are politicized and meddled in by politicians and bureaucrats who have close relationships with the national government. In addition, Kamnuansilpa, Wongthanavasu, and Ando (2013) argue that local governments in Thailand lack an incentive to promote local economy because they are not only controlled by, but also looked down upon by, the national government in terms of economic development capacity. They have been treated by the national government as the recipients rather than the generators. As a result, this causes in them a lack of incentive and capacity to stimulate the local economy and attract investment. These examples help illustrate that national political institutions shape economic performance at local level.

\section{Conceptual Framework}

The contributions of the three theoretical approaches discussed above help build the conceptual framework in this study (See Figure 1.1). First, the institutional theory describes the roles of formal institutions on social interactions and behaviors. Specifically, this study emphasizes the impacts of changes in formal institutions during political crisis on social interactions. In addition, instability of formal institutions may affect the progress of decentralization, the interplay between local government and local citizens, and the effectiveness of local governments in delivering public services.

Second, governance theory provides significant definitions of governance by drawing the evolution and development of governance concepts from the public 
administration perspective to the new public governance perspective. Importantly, this study employs three theoretical components of new public governance-civic engagement, collaboration, and leadership-to guide the analysis in this study. Civic engagement emphasizes collective action and socio-political interaction in order to enhance political decision-making, improve effective services, create social capital, and increase trust and transparency. Hence, it is interesting to see the patterns and levels of civic engagement in local activities through the lens of both formal and informal political participation in the midst of political crisis. In addition, collaboration provides the opportunities for building networks and working across boundaries. The emphasis of this study centers on collaboration among collective partners (informal collaboration) and collaborative deliberation among multiple stakeholders (formal collaboration) in local service provision.

The last governance component employed in this analysis is political leadership. The scope of leadership emphasizes contingency leadership, public service leadership, and crisis management leadership. Contingency leadership depends on style of leaders and situational factors. Moreover, the patterns of leadership in new public servicesawareness in social values, citizenship, empowerment, collective actions, effectiveness, and fairness-employed in this study concentrate on how local leaders and public service professionals provide and maintain local services by using these leadership patterns. Additionally, crisis management leadership provides a framework for strategic crisis 
leadership, which includes sensemaking, decision-making, coordinating, meaning making, accounting, and learning.

Finally, political economy theory provides two major dimensions of political economy that explain the inter-relationship and interactions between polity and economy. These two dimensions include the internal political economy and the external political economy. In this study, the relationship between politics and economics act as moderating variables that could affect the effectiveness of local government service delivery. 


\section{Chapter 3 \\ Research Methodology and Design}

This chapter describes the research design and methods employed for this study. The chapter consists of six sections: a rationale for an exploratory approach using multiple case studies; the research design; the site and case selection strategy; the data collection methods; data analysis methods; and data validity.

\section{Rationale for Exploratory Approach Using a Multiple Case Study}

This study explores how prolonged national political crisis in Thailand has affected local service delivery. To answer this question, this study looks at the antecedent conditions for local service delivery and considers national political crisis as an independent variable that interacts with five moderating variables to influence local government service delivery as an outcome variable. It is important to note that, in most cases, interviews tend to be subjective, which is why there is not necessarily a definitive difference between low- and high-performing cases on most variables. The question to be answered is whether local government service delivery has experienced a negative effect, a positive effect, or some combination of the two.

While the main focus of this study is not on the comparative analysis of how the high-and low-performing cases are affected by the protracted national political crisis, the author selected multiple cases for data collection. This helps to gain a better understanding of phenomena and events across a range of municipal jurisdictions and communities. In addition, the author feels that a multiple-case-study design provides 
multiple perspectives within a similar context, which may lead to future study of the "relationships and interactions" among local government's stakeholders (Buckwalter, 2014, p. 576). These stakeholders are both organizational and individual (e.g. municipalities, municipal leaders, community leaders, local residents, and municipal officers).

Data collected for this study are qualitative in nature and were collected by semistructured in-depth interviews and focus-group discussions. This sort of inductive data is not suitable to use for testing hypotheses (Nishishiba, Jones; Kraner, 2014), but rather provides "a more generalizable conclusion" about the cases themselves (Lawton \& Macaulay, 2014, p. 78).

As a multiple-case study, the fieldwork allows the researcher to interact with selected participants from different municipalities. These participants provided an “insider's view” through face-to-face, in-depth interviewing and focus-group discussions. Through this approach, the researcher gains direct information, e.g. real words, interactions, emotions, or gestures, from the participants who live and work with and experience those specific contexts or phenomena (Yin, 2014).

\section{Research Design}

To examine effects of national political crisis on local government service delivery, there were four steps for conducting this research. The first was research case selection. Using local self-collected revenue data available from 2009 to 2015, the author identified four municipalities within Khon Kaen province. Employing the Statistical 
Package for the Social Sciences (SPSS) program, the revenue data were used to stratify the municipalities into two groups: high- and low-performing cases. Two municipalities were selected from each of these groups, for a total of four municipalities in the study. How the four municipalities were selected will be discussed in detail in the next section.

The second step was protocol preparation and participant selection. Based on the research question, the author developed semi-structured questions for the in-depth interviews and discussion guides for the focus-group discussions. Prior to the interviews, the author tested the consistency of the questions by interviewing volunteers in order to ensure the interview questions were appropriate and clear. Having these practice sessions helped the author to become familiar with interviewing protocol and the interview questions. Before doing the fieldwork, the author recruited the participants based on their political or municipal stakeholder roles who were directly involved in local service delivery — both from the perspectives of service providers and recipients. The author specifically invited the participants who lived and worked in that municipality for at least one year prior to the date of data collection.

In the next step, data collection, the author collected interview data from four municipalities in Khon Kaen province. The participants for the in-depth interviews included municipal leaders and municipal councilors. For the focus-group discussions, the author invited community leaders, local residents, and municipal officers to participate. The reasons the author conducted two methods of data collection were to 
ensure both efficiency of time utilization and breadth of coverage. Conducting only indepth interviews consumes a significant amount of time and resources but may not capture the interaction of the members of the communities, whereas relying on in-depth interviews alone may limit the boundary and multiple perspectives of data due to the involvement of only one participant in each interview. Therefore, using both focus-group discussions and in-depth interviews makes best use of the time allotted and captures the diversity of data from individual as well as group perspectives, thus creating richness of data for qualitative analysis.

For confidentiality and human subject requirements, every participant received an explanation of the purposes of this study from the author and was provided a consent form (see Appendix E). Once the form was signed, the author asked for permission to use an audio recorder while interviewing, using those records for transcribing the interviews. For the interview locations, the author was permitted by the four municipalities to use the meeting rooms in the municipal offices to interview the participants.

The fourth step was data transcription analysis. After completing the two types of data collection, the data were transcribed from the audio recorder into text format. Both in-depth and focus-group discussion data reflected the opinions and experiences of the participants. In addition, the author reviewed and classified the interview transcripts into the systematic themes. The themes basically were built around the moderating variables discussed earlier. For the focus-group discussion data, the author used thematic reading 
and summarized the transcripts into themes according the five moderating variables. Moreover, the emotional interaction among the participants, i.e. gestures, sounds, laughter, or other nonverbal reflections, was included in this analysis. For capturing this kind of data, the author noted when the participants expressed such emotions during the sessions. The notes taken from the focus group sessions were added into the audio transcriptions.

For data collected through in-depth interviews, the author also coded them into themes according to the five moderating variables. Based on these variables, each theme was assigned a different color by using Post-it $\odot$ notes and pens. The author removed the names and the positions of participants from all transcribed documents before doing data validity. In order to confirm the data validity, the author asked two graduate students who have had experience with conducting qualitative research to review the transcripts.

Once the themes emerged and were consistent, the author started writing the research report. In this process, some of the more important and closely-related quotes from the interviews were identified and included in the report. These quotes provided evidence to support the arguments and descriptions. For anonymity, names and personal information of interviewees were removed from the quotes.

\section{Research Site Selection}

This research was conducted in four municipalities in Khon Kaen province. Khon Kaen province is geographically located in the center of northeast Thailand and is the 
largest province in upper Northeast region. The justification of selecting Khon Kaen province instead of the other provinces in the region included: (1) Khon Kaen is the center of economic, commercial, transportation, and logistics in upper northeast Thailand; (2) Khon Kaen is a hub of government service agencies, of which there are about 450 government agencies consisting of agencies of the central government, provincial administration, and local government; (3) Khon Kaen is the medical, health, and educational center in the region; ${ }^{5}$ (4) Khon Kaen Province has 225 local governments (1 Provincial Administrative Organization, 84 Municipalities, and 140 Tambon Administration Organizations), the highest quantity of any province in upper northeast Thailand ${ }^{6}$; and (5) Khon Kaen province is a major political base of the Pheu Thai party, the ruling political party before being overthrown by the military coup of 2014. These factors distinguish Khon Kaen Province from the other 19 provinces in the same region in terms of social, economic, and political characteristics (see Figure 3.1).

\footnotetext{
${ }^{5}$ Khon Kaen province strategic plan (2014-2017), link: http://www.khonkaen.go.th/

${ }^{6}$ Khon Kaen province has 225 local governments, which compose of 1 PAO, 1 City (Municipality), 6 urban municipalities, 77 rural municipalities (sub-district municipality), and 140 TAO. Source: Department of Local Administration as of March 9, 2015, link: http://www.dla.go.th/work/abt/index.jsp.
} 
Figure 3.1 Map of Khon Kaen Province and Research Sites

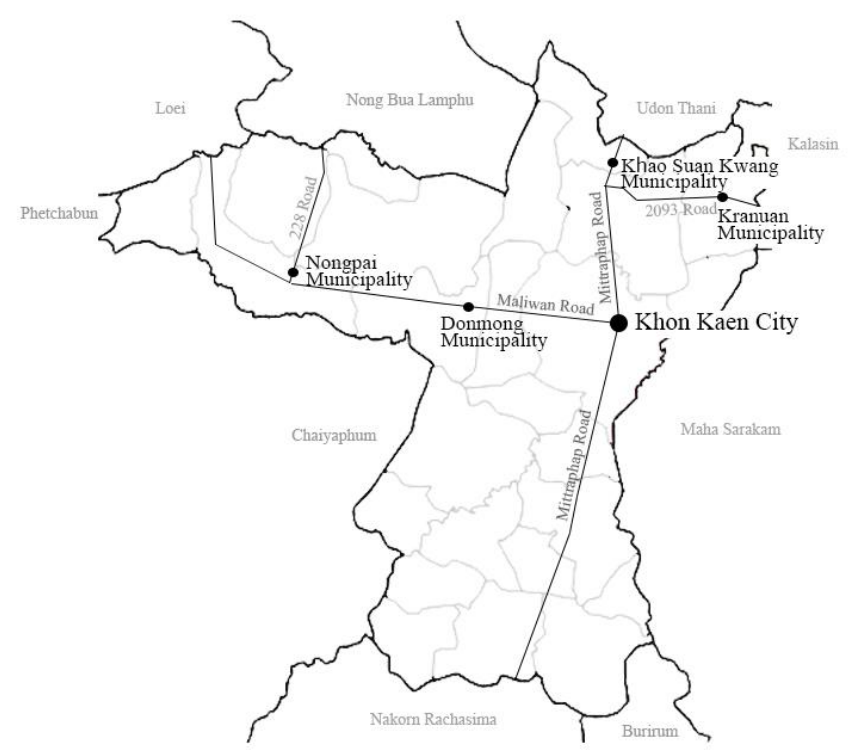

Source: Designed by the researcher, 2017.

The initial case selection was based on an attempt to find an objective measure of local service delivery. The most suitable, in the author's opinion, was local revenue collected. This is considered to be a causal or cause measure of local service delivery and is assumed to be an important input to local service delivery. To select four research sites, the author therefore used local self-collected revenue data from 84 municipalities in Khon Kaen province. These data collected covered the period from fiscal years 2009 through 2015. This was a period of significant national political events and changes in governments and policies in Thailand (e.g. two democratic governments, the Democrat Party and Pheu Thai Party; two coups d'état ending in military juntas, and significant political violence). The objective of the author was to identify and select two groups of 
potential case studies (high performers and low performers), each group consisting of two potential municipalities (research sites).

The average change in revenue of all 84 municipalities during 2009-2015, was $88 \%$. Low performance was considered to be less than $88 \%$ and high performance was above $88 \%$. The author chose the top 10 high performers and bottom 10 low performers. With these 20 municipalities identified, the next process was to select the two most relevant research sites for each group by using cluster analysis, followed by pairedcomparison analysis. The cluster analysis was employed for calculating some basic control factors that explain better revenue performance in the high than in the low. Then, the author used paired comparisons for matching cases that shared similarities and were relatively close. The cases that held the most similar control variables were selected for the data collection process.

For the research, the author felt that two cases in each group would be sufficient given the time allotted. Prior to paired comparison analysis, cluster analysis was used. The control variables the author used for cluster analysis were from the categories of: demography (population density); geography (distance to provincial town); history (year established); and revenue transfers (general grant and grant for local government). The author made these four categories worth $25 \%$ each and then used a scale of 1 to 7 for each category, where 1 indicated the lowest level of self-collected revenues and 7 the highest. 
The result of the cluster analysis showed that the three lowest high performers were Nong Sao Lao, Nong Pai-Chumpae, and Kra Nuan, which could be paired with any of the top low performers-Khao Suan Kwang, Nong Kae, and Don Mong. The author used paired comparison analysis to identify the most relevant cases that share similarities in terms of intuitive choices-e.g. culture, location, region, and other relevant factors. Finally, two potential pairs (four cases) were identified.

The first pair was Kra Nuan Municipality and Khao Suan Kwang Municipality. These two municipalities are located in the same region (northeastern part of Khon Kaen Province). They also share similar community characteristics and culture, e.g., they are considered semi-urban municipalities. Both have similar agricultural activities--e.g. sugar cane, rice, and rubber trees. Culturally, they are Buddhist communities and speak a dialect that is closely related to Lao. Kra Nuan is located along side of national highway connecting Khon Kaen Province to Kalasin Province. Similarily, Khao Suan Kwang is located along the national highway connecting Khon Kaen Province to Udon Thani Province (see Figure 3.1).

The second pair is Nong Pai Municipality and Don Mong Municipality. They share similar cultural and community characteristics as well as location and direction. Both are located in the Western region of Khon Kaen Province. Nong Pai is on a national minor highway which connects to a major national highway connecting Khon Kaen Province to the northern provinces of Thailand (Maliwan Road or Highway 12). Don Mong is located on this highway (see Figure 3.1). As in the first group, the residents 
speak the same Lao dialect and Buddhism is the main religion. Local people are predominantly farmers, with some working in local industries. The author used all the above information for research site selection to finalize the two pairs.

\section{Data Collection}

In this study, the data were collected from two types of interviews. For in-depth interviews, the participants included municipal leaders and municipal councilors. For the focus-groups, the author conducted the discussions with community leaders, local residents, and municipal officers

The first step was face-to-face, semi-structured interviews with three participants in each municipality:

Municipal Mayors. The author had expected to interview four municipal mayors, but only three were interviewed. The other mayor was not available at that time, but he assigned a deputy mayor to substitute for him. The author interviewed the municipal mayors in order to investigate their administrative experience, as they are local political leaders and local policy decision-makers. The interviews took about 45 minutes each and the interviews took place in offices of each municipality.

Municipal Councilors. The municipal councilors were interviewed in order to explore their views and experiences as policy makers, local legislators, and neighborhood representatives. The author interviewed one chair and one councilor in each municipality by assuming that a chair and a councilor can provide different perspectives. 
Prior to the in-depth interviews, the author developed an interview guide and used a semi-structured interview technique to conduct the interviews. Semi-structured interviews helped the author to control an interview protocol by using an interview guide (see Appendix C). Also, the author was able to adjust the interview questions following each encounter. It is of note that all three interviewees from each municipality were males. That notwithstanding, the interview data from these individual interviews provided the author an in-depth perspective from different political and policy actors. The in-depth individual interviews provided the author limited multiple perspectives of data, so the focus-group discussions were an essential part of the process.

The focus-group discussions for the two groups of participants gave the author a diversity of data useful for analysis. More importantly, focus-group discussions allowed the author to gain "several perspectives at once from the population of interest" (Nishishiba, Jones, \& Kraner, 2014, p. 102). During the focus-group discussions, participatory observation techniques were employed. This provided the author not only interview data, but the ability to note the interaction and participation among participants. In this study, the author conducted two focus-group discussions by dividing the participants into two segmentations; heads of municipal divisions and local residents.

Heads of Municipal Divisions. The focus-group discussions conducted with the heads of municipal divisions consisted of 5-6 participants from each community. The participants were from various divisions within the municipality, e.g. fiscal and revenue division, municipal personnel division, public health division, education division, public 
work division, and social work division. These participants provided the author with various perspectives on local government management and public service delivery as well as local-society relationships. For this group, the author selected the participants by considering the divisions that worked most closely with the community and intergovernmental agencies.

Local Residents. The focus-group discussions conducted with local residents had 4-6 participants from each municipal community. Each group consisted of some combination of local resident(s), a village headman, a village health volunteer, and a local entrepreneur. This group makeup provided various perspectives on citizen-local interactions, social collaboration, civic engagement, local economics, political leadership, and state-society relations. The participants were conveniently recruited and invited by the municipalities. Table 3.1 illustrates the sites, number of participants, and sex of the participants in the in-depth interviews and focus-group discussions within the four municipalities.

Table 3.1 List of Research Sites and Interview's Participants

\begin{tabular}{|c|c|c|}
\hline Municipalities & In-depth Interview & Focus-group discussions \\
\hline Kra Nuan & 3 (males) & 5 (male 4, female 1) / 4 (male 2, female 2) \\
\hline Nong Phay & 3 (males) & 6 (male 3, female 3) / 6 (male 4, female 2) \\
\hline Kao Suan Kwang & 3 (males) & 5 (male 3, female 2) / 5 (male 1, female 4) \\
\hline Don Mong & 3 (males) & 5 (male 4, female 1) / 6 (male 3, female 3) \\
\hline
\end{tabular}

Before conducting the research, the author received IRB approval from Portland State University. Before conducting the interviews, the author requested participants to read and ask questions about the consent form or any other concerns they may have had. 
Everyone expressed understanding of the information the author provided. They signed the consent form and seemed to be quite happy to participate in the interviews. Importantly, every participant allowed the author to do an audio recording. The author also asked them if they wanted a copy of the interview transcript for review, but no one needed that.

\section{Data Analysis}

The digital recording files were transferred to a secured drive. Then, the interview data were transcribed from the audio recorder into text format. For data analysis, thematic analysis was employed to analyze the interview data based on the research question and moderating variables as the analytical framework. In this study, the author employed the processes of thematic analysis presented by Braun and Clarke (2006). There were six steps in the analysis:

Familiarization with the Data. After finishing the interviews, the author transcribed the data from the digital files into text. The author became familiar with the materials by reading them and linking them to the analytical framework. Since the author collected and transcribed the interview data, the author interpreted and understood from the characteristics of data. The author also cross-checked in order to make sure that the transcripts were consistent.

Generating Initial Codes. While reviewing and reading the interview transcripts, the author summarized and interpreted them in a short version. Then, the author used 
some initial codes that helped develop the informal themes (see Appendix I). At this point, the author was able to see the initial features of the data and identify them in a systematic way.

Searching for Themes. The codes helped the author to develop themes by grouping them in a systematic way. Initially, there were a lot of interconnected ideas, but the author selected only the ones that linked to the analytical framework.

Reviewing Themes. In order to make sure that the themes selected were correct and suitable for further explanation, they were carefully reviewed again and linked to the interview data because those data can help support the themes when writing the report.

Defining and Naming Themes. The themes were defined in order to provide a clear sense for readers. This helps people to read and understand what the themes mean. In addition, it helped to organize the order of themes.

Producing the Report. In Chapter 4 and Chapter 5, the author put the themes in a table. The table illustrates some examples of themes that linked to the data presented. In this study, the author used the interview quotes to support the themes and related arguments.

For data validity, there are several questions that could be asked--whether the municipalities represent Khon Kaen, whether the interviewees were given honest answers, whether criteria settings and selection processes were influenced by a 
researcher, etc. In addition, there might be some concerns about reliability caused by unexpected variations such as time, environment, etc. For example, the data gathering in 2016 may accurately portrait the situations existing during this period, but may be different in the next 10 years.

In order to ensure data validity, data triangulation process through multiple experts was used during data analysis in order to decrease "the potential bias that comes from a single person doing data collection" (Patton, 1999, p. 1193). The author asked two graduate students who have experience with conducting qualitative research to review the transcripts. After the review, both of them agreed with the interpretation and the themes the author had developed from these transcripts.

Initially, the original interview quotes were transcribed into Thai language. To support the research findings, some relevant interview quotes that were significant and related to each theme were later translated into English. To ensure that the original interview quotes were correctly translated, the author asked an expert who had translating experience and familiarity with qualitative research to proofread for the consistency and accuracy of each quote. The names of interviewees remained anonymous throughout the validity review process.

With regard to reliability, the author attempted to enhance the reliability by practicing the interview protocol with the volunteers in order to get familiar with questions and interview conditions. In addition, the author asked each municipality to 
create a positive environment for the interviews by providing a meeting room for conducting the interviews. This reduced the possibility of unanticipated situations that may interfere with the reliability of the data collected from the interviews. Time of interview is also important for maximizing reliability. The author made appointment with the participants on a date and time of their convenience so they were not concerned or frustrated about business or personal situations they had to attend to at the time of the interviews. The author also made sure that the participants who were the municipal officers were granted permission to participate in the interviews so that they could participate in the interviews without worrying about revealing their own personal opinions.

While attempting to ensure that the reliability of data was not jeopardized, the author, however, could not control the conditions as the effects of crisis rise and fall over time. In other words, it is questionable whether a study a conducted in 2010 or 2012 would get the same findings. Similarly, if this study were to be conducted again 10 years from now, would we still get the same results? Only future research can test the reliability of the data and thus research results over time. 


\section{Chapter 4 \\ How National Political Crisis Creates Threats for Development in Local Government}

The research question asks how Thailand's national political crisis has affected local government service delivery. Thailand's national political crisis since 2006 raises concerns about its effects on local government service delivery performance. While there were studies that pointed out to the detrimental effects of protracted political crises, none of them looked at the interface of the moderating variables with political crises and the service provisions of local government.

It is widely accepted that political crises are threats to social, economic, and political development. The literature generally argues that a political crisis triggers government failures and undermines the progress of democracy (see Kurlantzick, 2011). Notable is that prolonged political turmoil due to military intervention causes formal institutional suspensions (e.g. constitutions and electoral systems), inefficient public services, and economic decline (Norton, 2012; Nikomborirak, 2016; Sethapramote, 2014; World Bank, 2016). The following section explores how Thailand's national political crisis interacted with five moderating variables to have a negative impact on local government service delivery.

It is important to note that one of the major themes that emerged from the interviews was that stakeholders perceived both threats and opportunities, and threats and opportunities were found in almost all cases. However, for the purposes of this study they will be presented in two separate chapters. Even though threats and opportunities are not 
conceptually distinct, they will be treated separately in this study. This chapter will deal with threats and the next, Chapter 5, with opportunities.

\section{Results}

The preliminary results indicate that groups of local residents and groups of municipal officials shared and understood the political crisis in the same way. Concepts that participants saw as negative effects included: political and social conflict, political violence, political protests, government policy and project suspension, economic downturn, and military directives. The focus-group discussions were guided by discussing prepared questions (see Appendix C). The discussions also prompted further questions.

In this chapter, the results demonstrate that participants saw the national political crisis as a threat to local service delivery. The data gained from the participants were thematically analyzed and presented through five moderating variables: political institutions; citizen engagement; political leadership; governance; and political economy.

\section{Political Institutions}

In this study, the literature on institutionalism focused on formal institutions (e.g. constitutions, formal rules, laws, and political structure). The main debates in the literature argue that changes in political institutions influence interactions among institutional actors - individual citizens and groups (i.e. organizations) in society. Importantly, these changes also influence the effectiveness of public service provision (March \& Olsen, 1984; North, 1990; Peters, 2012). Additionally, as Shah, Thompson, 
and Zou (2004) concluded, "institutional arrangement" (e.g. formal autonomy) impacts the outcomes of local public service delivery, which include "efficiency and equity" (p. 12).

For Thailand, formal political institutions shape patterns of policy making processes, government structure and authority, and bureaucracy (Hicken \& Selway, 2012; Painter, 2004). In some political contexts, formal political institutions (e.g. constitution, electoral laws) are constituted to serve political interests of influential individuals and groups in political society. The effects of change in one institution trigger constraints in the functions of other institutions, e.g. constitutional suspension affects the electoral system and political parties (Dalpino, 2012; Kuhonta \& Sinpeng, 2014; Waitoolkiata \& Chambers, 2015).

Since 2006, the continuing national political crisis in Thailand has resulted in the formal institutions (e.g. constitution, laws, bureaucracy, and political structure) being suppressed at the local level. This institutional breakdown affected not only individual actors, but also organizational actors - i.e. the status of local governments. The following results describe the effects of the institutional breakdown that negatively influenced the status of local government.

According to the data analysis, the post-2006 national political crisis created particular threats to political institutions, which include a weakened electoral mechanism and suspension of local autonomy. The main themes and samples of key responses gained from the participants are presented and summarized in Table 4.1. 
Table 4.1 Themes and Samples of Key Responses on Political Institutions

\begin{tabular}{|c|c|}
\hline Themes & Samples of Key Responses \\
\hline $\begin{array}{l}\text { Weakened electoral } \\
\text { mechanism }\end{array}$ & $\begin{array}{l}\text { “...local people wanted to have a local election; they } \\
\text { probably feel frustrated..." } \\
\text { "Because they were elected, they had to be accountable } \\
\text { to their constituency and concerned about their voters..." } \\
\text { "...national government has lost interest in local } \\
\text { government such as budget allocation and the like." }\end{array}$ \\
\hline - Suspension of local autonomy & $\begin{array}{l}\text { "We are limited to respond to what people need. Some } \\
\text { things are prohibited to do." } \\
\text { "Nowadays, it seems like we are moving backwards. } \\
\text { They pretend to give us autonomy, but they still withhold it." } \\
\text { "...they don't fully decentralize authority to local } \\
\text { government. They still maintain their power, which includes } \\
\text { duties, responsibilities, and autonomy." }\end{array}$ \\
\hline
\end{tabular}

Source: Samples of key responses in this table are selected from quotes from full interviews.

\section{Weakened Electoral Mechanism}

The main institutional threats arose from the suspension of local elections, the removal of local control of budgeting, and a shift of authority from the local to the central government due to a suspension of policies established by the previous elected government. The participants described how the post-2006 national political crisis weakened the electoral mechanisms (e.g. election law, party law, ballot type, campaigning rules, electoral financial law, etc.) (Kreuzer, 2000).

Since 2006, elected governments and legislators in Thailand have existed under a prolonged national political crisis. This was especially severe with the post-2014 military coup, when political institutional failure instigated by the junta resulted in suspension of regular elections at both the national and local levels. The military used the 2014 Interim Constitution to replace the 2007 Constitution. One result was that the democraticallyelected national government and legislators were suddenly removed. The military 
authority, the National Council for Peace and Order (NCPO), then appointed a military government. Thai election law as an important electoral mechanism was suspended and replaced by a non-democratic process. The current political parties have not been allowed to play any political role since. Politicians have been prohibited from becoming involved in any political activities at both national and local levels. Especially noteworthy is that local elections have been suspended until after the completion of a new constitution.

Due to the suspension of elections, local citizens lost their sense of representation in both national and local political institutions. It was difficult to give feedback and voice their preferences to the elected representatives. In effect, the representative role of the national legislature was abolished; however, local residents still wanted to have an elected government and elected legislature representing them at the national level. These suspended political institutions are important for local development in terms of political relationships, policy support, fiscal transfer, revenue collection, and infrastructure projects. Regarding this point, comments from participants included:

“...Nowadays, it seems like we don't have people who represent us. We don't have people who can help us. It's broken and disconnected." (Member of municipal council, personal communication, August 24, 2016)

“...The relationship is apparently estranged because national government has lost interest in local government regarding items such as budget allocation and the like." Member of municipal council, personal communication, August 24, 2016)

"Having national democratic representatives was good for us. We could follow up and know who represents us from our community. Because they were elected, they had to be accountable to their constituency and concerned about their 
voters..." (Member of municipal council, personal communication, August 24, 2016)

Since the post-2014 national political crisis, the NCPO suspended all local elections. To maintain service provision during national reform, the NCPO extended the terms of office for local politicians who were scheduled to end their terms during this period.

According to the interview data, there was only one municipality that obviously reflected the negative effects of the electoral suspension ordered by the NCPO. This case is important to address here because the suspension of local elections caused frustration among local citizens. Local people wanted to have an election. They should have had the opportunity to decide who would be their next mayor and next local legislators. Notably, the suspension of local elections undermined an accountability between local citizens and their elected officials. An interviewee stated on this point that

"Currently, local people want to have a local election, they probably feel frustrated. The mayor and some municipal councilors already finished their terms of office but they remain in power. Local people raised a question! We just told them it depends on the National Council for Peace and Order." (Municipal official, personal communication, August 24, 2016)

As observed, Thailand's 2014 national political crisis had more of an effect on political institutions than the 2006 political crisis, especially regarding the electoral mechanism. The following section will discuss the negative effects on the suspension of local autonomy. 


\section{Suspension of Local Autonomy}

The prolonged national political crisis weakened not only electoral mechanisms but also local autonomy, especially regarding budgets, because of a suspension of existing policies. National government policies are an important mechanism for improving local communities, stimulating economic activities, and maintaining intergovernmental relationships. Notably, Thailand's post-2006 political crisis caused changes in election policies and also undermined policy alignment between national and local governments.

Following the 2014 military coup, the military-installed government suspended, and even terminated, some social and economic policies created by the previous elected government. Some municipal leaders mentioned that the political crisis created barriers between local governments and national legislators in terms of financial support, budget allocation flow, and degree of development. Local governments found it difficult to request fiscal support from the national military-installed government. This relationship differs from the time of elected governments in that those governments tended to be more approachable and supportive. Regarding this point, some participants observed that:

“...We don't have a national elected legislature. Due to political suspension, it is difficult for us to ask for budget from national government to develop the local community”. (Member of municipal council, personal communication, August 30, 2016)

"...If municipal administrators have good connections with national legislature and government, we usually obtained the grants. It was difficult if they did not know someone there." (Municipal official, personal communication, August 24, 2016) 
"In the past, when we needed budget about 50-60 million baht for local development. We took local residents to ask for financial assistance from elected representatives." (Member of municipal council, personal communication, August 24, 2016)

Since the military government took power, local autonomy appears to be in decline, with some local duties being recentralized under the authority of national and provincial organizations. The decision-making authority became more highly centralized so that it was difficult for local governments to operate their services. It is important to understand that while there is less autonomy when the junta decides to get involved in governance, it decides to get involved in local governance less often than prior to the coup. The result is that while there is less autonomy for local government (which can be seen as a threat), there is also less interference in local government (which can be seen as an opportunity) as a result of central power not being exercised locally as regularly as in pre-coup Thailand. Seeing less interference as an opportunity will be discussed in further detail in Chapter 5. Regarding the decrease of local autonomy, an interviewee reflected that:

"The limitation of local administration is something like when we want to solve some problems and respond the needs of local people. We are limited in our response to what people need. Some things are prohibited. They (central government agencies) just said it might be illegal." (Municipal councilor, personal communication, August 30, 2016)

Political turmoil since 2006 delayed the progress of decentralization, which was a power-sharing mechanism connecting national and local political institutions. Often, local governments have been accused of corruption and functioning as nontransparent 
organizations. The national government took this opportunity to interfere with some local duties and to pull back local autonomy, especially regarding budgeting.

An interesting example given by some of the participants was the creation of a politicized policy called the "Pracha-Rat Project" or "People's State Project." This policy aimed to boost local economies and quality of life by allocating block grants through ministries, provincial authorities, districts, villages, and business sectors instead of directly distributing grants to local governments (Jikkham, Mala, \& Sattaburuth, 2015). This politicized policy eroded the progress made toward the decentralization to local governments and its role in relation to the higher governing institutions. Most projects granted by the national government invested in the fundamental infrastructure of local communities. However, municipalities, as the main local service providers, were not empowered to be responsible for these projects. Regarding this point, one of the participants stated that:

"I personally thought that they (central government authorities) tried to pull them back. Nowadays, it seems like we are moving backwards. They pretend to give us autonomy, but they still hold it." (Municipal official, personal communication, August 30, 2016)

When the national government allocated grants for local infrastructure development projects in local areas, the national government and provincial authorities should have involved the local leaders in the funding process for that project, but they did not. Instead, the national government reduced local autonomy on budgets by transferring 
the grant and mandated decision-making authority to the District Chief Officers, who are appointed by the central government. On this point, a municipal mayor expressed that: "No, they don't [involve the local leaders], because this grant was transferred directly to the District Chief Officer to implement government policy. If each subdistrict receives 5 million baht, right? They have to spend that grant for road improvement projects following the needs of the local community. But they still need our assistance in terms of construction specialists in order to calculate and estimate the project construction costs. They still borrow our staff..." (Municipal mayor, personal communication, August 30, 2016)

In addition, the suspension of local autonomy affected the local governmentcitizen relationship. For example, one municipality provided financial support to local communities in order to promote local culture and tradition. During an elected government administration, it was very common for local governments to support such activities. Currently, municipalities have been prohibited from supporting or funding these same activities. As noted by some participants, the Office of General Auditor of Thailand suggested that traditional and cultural activities should be voluntary among local citizens, thus financial subsidies provided by municipalities would be recognized as an act of noncompliance. This limitation reduced the autonomy of local leaders to initiate new policies or support similar activities for local communities. Some participants presented these perspectives:

[Referring to a local sporting event] "If people are not the athletes, the law does not allow us to buy them the sportswear. Last year, I just returned money to government due to an act of non-compliance. When we had traditional and cultural events, such as a Songkran Festival, we've not been allowed to provide financial support for the local community in order to organize and decorate the procession. The government said this kind of activity should be a voluntary activity." (Municipal mayor, personal communication, August 30, 2016) 
"It looks like we did everything wrong. Why do I have to do that? I can't sleep and I am concerned about doing what I don't want to do. I want to do the things that local residents agree are good for them. When we do something, the national auditing office told us that we acted in non-compliance on that project. We've encountered the difficulty. We would like to comply but at least they should provide us the right regulations that help avoid the act of non-compliance. We're happy to have that." (Municipal official, personal communication, August 24, 2016)

"One problematic issue that constrains our administrative mission is the activity that is related to local tradition and culture. For example, on the Buddhist Lent Day our municipality wanted the community to organize an activity. We cannot provide them financial support because the Office of General Auditor of Thailand does not allow us to do that. We cannot even support the costumes and make-up for the traditional dancers..." (Member of municipal council, personal communication, August 24, 2016)

"My point of view is that it is not a real autonomy. For decentralization, they don't fully decentralize authority to local government. They still maintain their power, which includes duties, responsibilities, and autonomy. They like pushing the fault to us instead of facilitating us to do it the right way. The regulations and laws do not accommodate us to work properly. If we don't do anything, people complain and blame us. This affected us a lot. We work closely with people in the local community, but we cannot respond their needs, so people complain about us." (Municipal official, personal communication, August 31, 2016)

The participants perceived that local autonomy, especially on budgets, has been undermined. For example, the actions of the office of the Auditor General of Thailand (an autonomous governmental sector) in one case lead to a prime example of this kind of insecurity for local leaders. In this case, local governments were accused of corruption. The national auditing agency actively began checking local administrative transparency, especially regarding local expenditures and noncompliance issues. This auditing authority 
appeared to be very active during the administration of the military government, as underlined by these comments:

"The current government created a lot of problematic issues for us. They became government by a military coup. For local government, citizens elected us. We don't like that they are accusing us as the corrupted local government. It's not true! Each process follows transparent procedures. There is the rule. We do everything following the orders and laws. When a mayor ordered or assigned municipal staff to do something. If it is considered an act of non-compliance, municipal staff just avoided doing it. They carefully protect themselves to do that." (Member of municipal council, personal communication, August 24, 2016)

Moreover, since 2014, the military government suspended some local

development projects and local expenditures even though those projects were needed for improving local public services, such as supplying new fire trucks. Instead, the national government provided financial support to provincial authorities (the governor's office, and the district, sub-district, and village agencies) for all development projects. All the issues described above resulted in losing local autonomy. One of the participants reflected that:

"There were the effects because our annual budget was not enough. We have long term vision to do something but we cannot operate on that. It looked like we lied to our people. If we received $35 \%$ of the annual grant, we could manage everything. For example, nowadays we have two fire trucks. We wanted to buy another but we cannot because we don't have enough budget. We wanted to buy it this year but all local project expenditures were terminated. Each project was suspended. For example, some government policies wanted to stimulate economy..." (Member of municipal council, personal communication, August 25, 2016)

Importantly, the participants emphasized that the important laws related to decentralization and local autonomy were suspended. Centrally-elected legislators 
worked during these hard times because of the dissolution of the parliament. The military-installed government and its legislators have focused on solving the political crisis and conducting political reform rather than concerning themselves with strengthening formal political institutions. Newly imposed legal constraints began to threaten local decision-making in providing services. Due to new regulations, local governments encountered difficulty in making decisions on budgets. Concerning this issue, an interviewee expressed that:

"Local governments encountered the difficulty on spending local expenditures. They [the current military government] don't review and revise the laws and regulations that are related to local expenditures. We have money we have saved, about 50-60 million baht, but we cannot use that due to the non-compliance with those regulations." (Member of municipal council, personal communication, August 24, 2016)

In addition, the existing laws were not able to respond to current complex problems, which varied by community. The laws imposed by the central ministries limited local autonomy. Problems in local communities should be solved by local people through local governing processes, not by central ministries. The process of decentralization has been reversed during the political crisis because central ministries have tried to suspend local autonomy and designed the regulations without understanding local contexts and local needs.

Local people realized that local governments are public service providers that are closer to them than central governmental agencies. They expected that local governments should have full autonomy to decide local policy and provide services. Local 
governments now have limited autonomy that is influenced by national and provincial administration. Regarding this point, one of the participants stated that:

"Actually, local administration has a problem with the conflict between regulations and implementers. Sometimes we cannot do anything because of the limitation of regulations and laws. The auditing authority does not care whether or not you are corrupt. They restricted the laws and regulations we are using. Actually, a group of national government officials working at the national authorities creates the laws and regulations. Nowadays, there is only that group that influences and controls local government official. These officials work in the departments within the ministries. They designed and made the laws and regulations. This created the problem because they did not understand the real problem and needs of people at local level. It does not get along well." (Municipal official, personal communication, August 24, 2016)

The national political crisis negatively affected not only political institutions but also civic engagement at the local level. The following section will describe the negative impacts of Thailand's post-2006 national political crisis on civic engagement that can be a moderating variable for effective local service delivery.

\section{Civic Engagement}

The central debates in the literature on civic engagement argue that engaging citizens in the process of public decision-making enhances transparency and legitimacy. Importantly, it induces effective public services and improves government performance (OECD, n.d. para.1). In new public governance, civic engagement is one of the vital mechanisms that helps promote public participation in policy processes and voluntarism in public service provision (McLaverty, 2011; Peters \& Pierre, 1998). In addition, new governing processes value civic engagement as a way to build networks and coordination between citizens and the public sector in public policy processes. It also creates a positive 
impact for the progress of participatory democracy (Bureekul, 2009; Holmes, 2011; Michels \& Graaf, 2010; Peters, 2011). Civic engagement is difficult in particular political contexts because government and political power-holders are hesitant to engage citizens in some public activities. Those political power-holders may be concerned about being subjected to transparency and accountability laws that inspire citizens in a democratic society (Bureekul, 2009).

To explore how civic engagement as a moderating variable impacts local service delivery in the midst of national political crisis, the participants in both in-depth interviews and focus-group discussions were guided by the interview questions (see Appendix C). The findings show that Thailand's post-2006 national political crisis has created threats to civic engagement, which include three main themes: (1) reduced civic participation; (2) weakened policy networks; and (3) increased civil conflict. These findings are also presented and summarized in Table 4.2. 
Table 4.2 Themes and Samples of Key Responses on Civic Engagement

\begin{tabular}{c} 
Themes \\
- Ramples of Key Responses \\
\hline "Nowadays it is prohibited to have a public \\
gathering of more than five people. This undermines \\
rights and freedoms of Thai people." \\
"When we want to invite the villagers to patriciate in \\
some activities or share their voices, they feel fear to \\
join the activities." \\
"They were not allowed to do any political activity \\
nor even meet with their advocates. How could they \\
know the needs and problems of people in local \\
communities?" \\
"Actually, the MP should be allowed to meet and ask \\
people what they needed and what problems they have \\
encountered with." \\
"Nowadays, people divided themselves by colors." \\
"Obviously, people can't talk or even don't talk to \\
each other. This change triggered increasingly conflict \\
among people in the community". \\
"People don't like each other. Also, the community \\
committee is from different side. It's very difficult for \\
gathering or asking people to do activity."
\end{tabular}

Source: Samples of key responses in this table are selected from quotes from full interviews.

\section{Reduced Civic Participation}

The findings indicate that since Thailand's post-2006 political crisis, the freedom of expression of political opinions was reduced, if not totally prohibited, thus discouraging the public from civic engagement. It is important to note that there are differences in civic participation at the national level and at the local level. This study indicates that civic participation in matters related to national affairs has declined, particularly those related to politics. The situation is different at the local level, as citizens participated more in local affairs. This point will be discussed in greater detail in the next chapter. 
After the 2014 military coup, the military-installed government imposed martial law to limit citizens participating in political activities. Citizens were no longer allowed to talk openly about politics or gather in a group of more than five persons in public. As a result, local citizens felt fear and anxiety around engaging in national political activities or even just complaining about the government during this period.

Martial law also caused the decline of public engagement in local activities. For example, when a municipality invited local residents to participate in public meetings that required collective decision-making, the local residents were reluctant to attend because they were afraid of being in a gathering of more than five people. This created barriers blocking the flow of important public participation on public policy processes.

Surprisingly, some participants stated that even though local people disagreed with certain military orders and laws, no one opposed the decision to enact these laws. Regarding this point, participants shared their perspectives:

"It affects us a lot. There are changes in laws and regulations. In the past, we have had freedom to gather and talk. Nowadays it is prohibited to gather publicly with more than five people. This undermines rights and freedoms of Thai people." (Member of municipal council, personal communication, August 25, 2016)

"Nowadays, municipality avoided organizing the activity that may involve in politics. They were afraid of being investigated for a gathering of more than five persons. Some people said, any activity that was organized by municipality, I didn't want go." (Member of municipal council, personal communication, August 24, 2016)

"...If there was a change in politics, then the law was enforced over the public wishes. People cannot oppose that change. I heard people talk against this change, but no one can oppose their power, because they feared the laws and 
regulations that were enforced by the military. They feared being arrested..." (Municipal councilor, personal communication, August 25, 2016)

Since the military took over in 2014 , most activities relating to politics have been prohibited. Even though local governments and communities were allowed to organize some public activities, such as sports, religious, social, and traditional activities, the military government still keeps an eye on those events and explicit political activities have not been allowed. Even though citizen input is vital for improving local service performance, political fears have impeded local attempts to build effective citizenship and find venues to share their thoughts or offer feedback. Some participants expressed their notions regarding this issue as follows:

“...It's different nowadays, with a government that was installed by the military. When we want to invite the villagers to participate in some activities or share their voices, they feel fear to join the activities. They are afraid that the military may call them to the military fort. Nowadays, we cannot freely express our voices as usual. This impeded the understanding of local people. Some understand, some don't. We are uncertain about talking to you openly. We don't like this type of political form." (Member of municipal council, personal communication, August 24, 2016)

"People are afraid of prohibitions, for example, after the military coups people are not allowed to politically gather more than five people. People respect the rule because of fears and anxieties. In the recent coup, people fear the rules and orders of military installed government." (Municipal councilor, personal communication, August 25, 2016)

Political fears and anxieties resulted in not only a decline in freedom of expression and municipal engagement, but also a decrease in political feedback from local citizens. Since the military coup in 2014 and the military-installed government took 
power, Section $44^{7}$ has been enforced. This law gave authority to the head of the NCPO to rule the country and deal with all political and managerial problems, causing an increased sense of fear and anxiety in the citizenry. Consequently, these fears and anxieties decreased political awareness and reduced constructive forms of political feedback. People lost interest in politics and public issues and abandoned the values and responsibilities of citizenship. The participants expressed their perspectives on this point: "In the past, we used to have a protest but after the coup d'état we didn't have it anymore. We are afraid of being carried to a cold room (military base). No one wanted to challenge that. I feel that people get really tired of politics. It's different from the past; we had energy when we talked about politics." (Local resident, personal communication, August 31, 2016)

"This is an absolute power; nobody can say anything, right? Section 44 of the interim Constitution has been enforced, so don't talk too much." (Municipal mayor, personal communication, August 24, 2016)

"The enforcement of Section 44 affected some citizens. We don't know how they prove whether it is a real mistake or false mistake, if someone just complains and reports some issues to government. During an investigation, they enforced Section 44, so that person was suspended from his job." (Member of municipal council, personal communication, August 24, 2016)

During national political crises, local people are less interested in political news.

In the past, political issues encouraged people to follow the news. They wanted to know what was going on and how politics would impact their lives. Currently, local people do

\footnotetext{
${ }^{7}$ Section 44 refers to a section in the constitution that was promulgated by the NCPO in 2014, which gave power to the head of the NCPO, who, as it happens, is also the Prime Minister (see Chapter 5 for complete wording of Section 44). When the 2017 Constitution superseded the 2014 interim constitution, the powers under Section 44 were transferred to Section 265 . However, the term "Section 44 " is still generally used to refer to these powers.
} 
not want to even turn on the television, especially on Friday evening when the nationwide television channels broadcast the weekly address of the Head of the National Council for Peace and Order and the Prime Minister of Thailand. It seems like they refused to listen to news and information that is related to politics. Political fears and uncertainties reduced feedback from local residents and also created barriers to receiving information from the national government. Regarding this point, local residents expressed their opinions:

"On Friday, I didn't want to watch television. When I turned it on and saw that program, I just wanted to turn it off right away." (Local resident, personal communication, August 24, 2016)

"In the past, during the new constitutional referendum, I didn't see even the draft of the new constitution. Give me a copy of the constitutional draft please? I've not seen it even as of today. I don't know whether or not it was distributed. I got bored with politics. I don't want to even read the news." (Local resident, personal communication, August 31, 2016)

An engaged citizenry offering feedback concerning local issues is important to improving local government service delivery. Since 2006, the ongoing national political crisis has created a political barrier for citizens to get involved in local public activities, especially local political participation.

Moreover, political uncertainties and fears made local people lose trust in the direction of the government and its economic policies, especially the policies created by the current military government. This negative impact undermined the progress of social trust and social capital in local communities. In developing democratic societies, public trust is built upon active civic engagement. Civil society should have the confidence to 
interact and work closely (co-production) with public organizations without uncertainties and fears. Also, active civil participation and a high degree of value sharing trigger the improvement of social capital (OECD, 2011).

This study found that the political crisis created uncertainties and fears that resulted in decreased trust in creating or expanding previously existing economic activities. In addition, changes in the government and its policy discouraged local people's interaction with each other as well as with their government. They were also less willing to form community networks. Sharing common values was impeded by political uncertainty and fear:

"When we talk about the connection between local government and local residents, we think that local government should have to provide an incentive for encouraging local people to participate in municipal activities. That strategy is wrong and it looks like we are stepping back. In reality, if people get benefits (income) from what they are participating in, they are OK to come. Now, when they participate in municipal activities, they have to leave their jobs and lose income. So, municipality should consider having an incentive as compensation in order to attract them to come..." (Municipal official, personal communication, August 24, 2016)

As an interviewee mentioned above, it appears that local people lacked incentive to participate in community activities, some ignoring all involvement in even social activities. They believe that they should spend their time making money to take care of their daily needs, rather than becoming involved in political activities and public influence. In some municipalities, people considered money an important incentive for them in deciding whether to attend and engage in public activities. The participants shared these perspectives: 
"For social involvement, people are likely concerned about working and making money to live from hand-to-mouth, so they lose interest in participating in social activity. (Member of municipal council, personal communication, August 30, 2016)

"...Comparing the pattern of social involvement between nowadays and in the past. In the past, we can gather our neighbors to help at harvest time. Nowadays, we have lost that kind of activity, especially when we planted rice and harvested rice. I think society and economy have been changed. People get in trouble and become poor. They just wanted to make money." (Local resident, personal communication, August 31, 2016)

The political crisis undermined not only public trust and reduced local civic participation, but its effects weakened interactions among social actors that are source for policy networks.

\section{Weakened Policy Networks}

Participants expressed the opinion that political fears and uncertainties reduced not only civil participation in local public service and local activity but also weakened policy networks. Especially after the 2014 military coup, the military-installed government has repeatedly used Section 44 of the interim Constitution to justify the implementation of martial law to evade regular laws. As a result, the connection between lawmakers and policymakers has been eliminated.

Some thoughts provided by the participants emphasized that national legislators were not allowed to interact with local citizens. Most political activities were prohibited by martial law and the military's orders. Local citizens were not allowed the flexibility to involve themselves in political activity. In contrast, under the previous elected government, representatives usually met with their constituents at the local level in order 
to obtain engaging feedback regarding potential problems for the legislature. Now, due to political institutional breakdown, state-social interaction has declined. Network and policy actors at the local level are uncertain about initiating new policy ideas and innovations. One participant observed that:

"Currently, the legislators are constrained by laws and regulations imposed by military-installed government. They are not allowed to do any political activity or even meet with their constituents. How could they know the needs and problems of people in local communities? Does the current government believe that the former elected legislators would try to further their political interests regarding this movement? Actually, the MP should be allowed to meet and ask people what the people need and what problems they have encountered." (Member of municipal council, personal communication, August 25, 2016)

When military officials replaced the former elected legislators, these legislators were, of course, out of office. Nonetheless, they can still serve as the link between local communities and central political institutions. Gathering feedback and maintaining the coordination of local input was a collective and engaging mechanism within the policy network of the previous elected government. The deconstruction of this policy network reflects a declining state-society interaction under the military government.

Due to the constraints of new laws and regulations, local governments and citizens became tired of the military government. The government did not attempt to rebuild mechanisms to bring feedback from the local level to develop their national policies. Instead, they created legal barriers to constrain the freedom of decision-making and civic participation in local governments. As the participants mentioned, local governments wanted to provide services for their local residents, but the limitation of laws and the 
orders enforced by the central government impeded local government to support those policies, even though some local activities still remained from the previous government. The constraints induced a weariness that discouraged local government and local citizens from participating in public activities that would provide feedback to the central government. The participants reflected their perceptions through focus-group discussions:

"In town hall meetings, local people agreed and needed to have something from the municipality, but we cannot do as we agreed. For example, people needed to have the ponds and the roads. When we asked, [the central] government did not agree. It was not the right way to do so. We just followed the government's directions because our budgets relied on government subsidy..." (Local resident, personal communication, August 24, 2016)

“...Each community has different problems and needs. [central] Government just wanted them to do and have the same thing. For example, the government said that this money should be used for buying fertilizer. All 98 villages of ... district just bought fertilizer, even though some villages did not have any problem and they also did not want to use fertilizer. This affected us a lot." (Local resident, personal communication, August 24, 2016)

"In the recent Songkran Festival, we could not organize a Songkran procession because the Office of General Auditor of Thailand said a municipality cannot provide budget to support Songkran activities. As a result, people did not participate. Actually, local residents from each community want to engage in particular activities, but laws and regulations imposed by the military-installed government constrained civic engagement at the local level." (Local resident, personal communication, August 30, 2016)

The effects of the national political crisis not only undermined policy networks in local government but also resulted in enhancing civil conflict among local residents who have different political beliefs. 


\section{Increased Civil Conflict}

Discussions with the participants across the four municipalities reflected that the prolonged national political crisis since 2006 has caused conflict among local residents, especially for people who are politically polarized. The conflict in the national political institutions divided people into two sides. People on each side identify their political stance by the color of their shirts. A red shirt represents people who are advocates of the Pheu Thai Party. Red-shirt people are also the major political supporters of the former government of Yingluck Shinawatra and are influenced by Thaksin Shinawatra, Thailand's former Prime Minister in exile. Most red-shirt advocates are also based in Northeastern Thailand, where my research sites are located. Conversely, a yellow shirt represents people who oppose Thaksin's administration. They also have political connection to the Democrat Party and supported the military-installed government (BBC News-Asia Pacific, 2012).

The political conflicts caused by political institutional failures appear to have increased civil conflict within local communities. This civil conflict resulted in reduced civic participation in local activities. One of the participants expressed this notion, describing that:

"It is a long story for the conflict among citizens. Nowadays, people divided themselves by colors." (Municipal councilor, personal communication, August 24, 2016) 
In some local communities, political conflict among local residents discouraged people from talking to those who oppose their political affiliation, creating increased levels of animosity among local residents. In traditional forms of democratic society, citizens express their opinions and needs at municipal town-hall style meetings. Since 2006, if people anticipated members of the opposite group coming to town-hall meetings, they would avoid the meeting all together. This divided not only communities, but also split families.

An interviewee mentioned that a husband and a wife watched different political news programs because they had different political stances and could not bear media that was sympathetic to the other side. This type of political conflict undermined any productive sense of citizenship or pride in one's local community and limited individual interaction with local governments. Even though the status of the current political crisis seems to be more peaceful, these conflicts have resulted in a declining interest in local politics. It has resulted in creating a barrier for local governments to gain feedback from its voters. Some participants explained the features of political conflict in their local community as follows:

"I can say that it's very obvious. People can't talk or don't talk to each other. This change triggered increasing conflict among people in the community. People obviously divided and identified their political belief by colors. It even happened that people hate each other if they know they talk to the opposing group." (Vice Municipal Mayor, personal communication, August 25, 2016) 
"When we hold a meeting, the opposite side does not come when they know the other group will be coming. This happened not only in our community, but also in some families..." (Local resident, personal communication, August 25, 2016)

"If one group is doing something, the opposite side won't come. It becomes a problematic issue especially in [this] community. People don't like each other. Also, the community committee is from different sides. It's very difficult for gathering or asking people to participate in an activity. It's not easy." (Local resident, personal communication, August 25, 2016)

The national political crisis caused not only a political institutional breakdown of local government status and weakened civic engagement, it also resulted in the decline of political leadership. The following section describes how the national political crisis has eroded local political leadership.

\section{Political Leadership}

The main debates in the literature on political leadership argue that public leaders who have leadership competencies help increase the efficient and effective organization of public services (Wart, 2003). In addition, public leaders should have the ability to control and maintain an organizational alignment with political changes and political pressures from both internal and external forces. Leaders should have decision-making skills on public service operation and provision, especially in difficult situations (Fiedler, 1996; Wart, 2003). In classical contingency leadership, public leaders should have full autonomy that includes administrative power and decision-making power in order to achieve organizational goals (Fiedler, 1971). In the literature on leadership in Thailand, the patterns of leadership focus on contextual leadership and leaders at the individual level who have leadership skills (e.g. skills of preparation and prediction for future, 
network building skill) to cope with contingent situations (Charoensiri, Getsuwan, \& Girdwichai, 2016; Krueathep, 2004). This study, however, investigates local political leadership at the individual level.

To explore how local political leadership as a moderating variable affects local service delivery in the midst of national political crisis, the participants in both in-depth interviews and focus-group discussions were guided by the interview questions (see Appendix C). Based on interviews of the participants, the post-2006 national political turmoil in Thailand created particular threats for political leadership at the local level. The findings present two main themes; reduced autonomy of local leaders and increased risks for local leaders. The findings are presented and summarized in Table 4.3.

Table 4.3 Themes and Samples of Key Responses on Political Leadership

\begin{tabular}{|c|c|}
\hline Themes & Samples of Key Responses \\
\hline $\begin{array}{l}\text { - Reduced autonomy of local } \\
\text { leaders }\end{array}$ & $\begin{array}{l}\text { "I want to do the things that local residents agree are } \\
\text { good for them. When we do something, the national } \\
\text { auditing office told us that we were non-compliant on } \\
\text { that project." } \\
\text { "Its effects created inconvenience for local autonomy" }\end{array}$ \\
\hline $\begin{array}{l}\text { - Increased risks for local } \\
\text { leaders }\end{array}$ & $\begin{array}{l}\text { "People can complain that we don't work" } \\
\text { "We work for local community and work closely with } \\
\text { local people. Unfortunately, we cannot serve the needs of } \\
\text { people. Eventually, we got complaints from local } \\
\text { people." }\end{array}$ \\
\hline
\end{tabular}

Source: Samples of key responses in this table are selected from quotes from full interviews.

\section{Reduced Autonomy of Local Leaders}

The findings indicate that most local leaders had the capacity to maintain public service provision, but they lacked confidence and were reluctant to use their autonomy for making some policy decisions. Especially after the 2014 military coup, political and 
legal constraints did not accommodate local leaders to be able to respond to the concerns of local citizens. For example, municipal mayors wanted to provide financial support for local communities to organize traditional activities such as the rocket festival, Thai New Year festival, etc. Formerly, local leaders had autonomy to approve local budgets to support local activities without any national concern or investigation. Political uncertainties and legal limitations suspended the capacity of local leaders to make the decision to undertake similar projects. Local leaders perform routine administrative duties, but they lack decision-making power. Regarding this point, some participants stated that:

"It looks like we did everything wrong. Why I have to do that? I can't sleep and I am concerned about doing what I don't want to do. I want to do the things that local residents agree are good for them. When we do something, the national auditing office told us that we were non-compliant on that project. We've encountered difficulties. We would like to do right, but at least they should provide us the right laws that help avoid the act of non-compliance. We're happy if we have that." (Municipal official, personal communication, August 24, 2016)

“...Its effects created inconvenience for local autonomy...In the past, they [local leaders] had done that ...Nowadays, they can do nothing. Anyway, they are trying to find solutions. It happened like that so it's very difficult for their

administration." (Local resident, personal communication, August 24, 2016)

The national political crisis reduced not only autonomy of local leaders, but also increased risks for local leaders in making decisions and serving local residents. ${ }^{8}$ The

\footnotetext{
${ }^{8}$ It is important to note that while overall leadership autonomy decreased, the roles of the mayors are more recognized by the local citizens, thus elevated. The author will discuss about this point again in Chapter 5 .
} 
following section will discuss how the national political crisis created risks for local leaders.

\section{Increased Risks for Local Leaders}

The weakening political leadership became one of the negative effects caused by the national political crisis. Local leaders lacked autonomy to make certain decisions, especially regarding budget approval. Moreover, political turmoil and legal constraints increased risks for local leaders in two aspects. First, due to these limitations, local leaders have tried to solve problems and help out local residents to get financial support from the municipality by using what autonomy they do have. This shows that local leaders still have some capacity and autonomy to make decisions on local budgets, but this may increase risks for local leaders in terms of fiscal non-compliance monitored by centralized authority. For example, we can look at one important national event, the National Day for Older Persons. Normally, the mayors can approve the budget to buy mementos for older residents who attended the municipal activity. Recently, due to an act of fiscal non-compliance, the mayors cannot use local budget to buy and offer mementos to older persons. Regarding this issue, one of the participants reflected that:

“...This is our important national day but we [local leaders] cannot give anything to them. Our decision is legally monitored by the National Audit Office. Actually, we want to honor them. We have enough budget, but we cannot use it. This affects municipal administration a lot." (Member of municipal council, personal communication, August 24, 2016).

The other risk political leadership constraints caused for local leaders was in terms of public complaints and losing public trust. When some local leaders are faced 
with decision-making and problem-solving, especially on budgeting and some local policies, they have the personal capacity to determine solutions and please local residents. However, those local leaders who lack personal skills in problem solving and were fearful of making the wrong decisions, so they made no decision. These local leaders with low capacity then risked getting complaints from local residents, resulting in losing leadership trust. Eventually, its effects could trigger negative impacts for future political popularity (i.e. local elections) of those leaders. Regarding this point, one of the participants expressed that:

“...Regulations and laws are not able to accommodate our work. But, if we don't do anything, this eventually affects us. People can complain that we don't work. We got a lot of effects from this issue. We work for the local community and work closely with local people. Unfortunately, we cannot serve the needs of people. Eventually, we got complaints from the people." (Municipal official, personal communication, August 31, 2016).

“...Last year I didn't dare organize the Songkran Festival. We actually wanted to stimulate local economy. If we had Miss Songkran Contest, we would have had 13 competitors. But giving rewards is prohibited, so we don't have any reward for this contest. In the past, we supported the festival with a budget for dressing up and rewards for the processions." (Municipal mayor, personal communication, August 30, 2016).

\section{Governance}

The majority of the literature on governance argues that the term "governance" as used in public organization refers to new governing process that values interactions among societal actors, collective actions, inter-organizational collaboration, powersharing, and networking (Enroth, 2011; Peters \& Pierre, 1998; Renn, Klimke, \& Asselt, 2011). These new patterns of governing processes aim to replace the limitations of 
conventional public administration that emphasized state-centered approach (Rhodes, 2007; Stoker, 1998). The impacts of governance in public organizations help improve voluntarism in public service delivery, state-local interaction, intergovernmental collaboration (i.e. blur boundaries), and a bottom-up style of administration (Kickert, 1997; Peters, 2011). Thailand's post-2006 national political crisis repeatedly entailed changes in politics and policies at all levels of governance. A question has been raised regarding its effects on governance as a moderating variable to local service delivery. Importantly, having good governing processes induces effective public service delivery (Bowornwathana, 2000)

In order to explore how governance mechanisms mediated local government service delivery in the midst of political crisis, the participants in in-depth interviews and focus-group discussions were guided by interview questions (see Appendix C).

Based on the viewpoints of participants, Thailand's post-2006 national political crisis entailed threats for governance in two ways: (1) decreased trust and communication between central and local government; and (2) hierarchical interactions in internal governance settings. These effects are presented and summarized in Table 4.4.

Table 4.4 Themes and Samples of Key Responses on Governance

\begin{tabular}{ll}
\multicolumn{1}{c}{ Themes } & \multicolumn{1}{c}{ Samples of Key Responses } \\
\hline $\begin{array}{l}\text { Decreased trust and } \\
\text { communication between } \\
\text { central and local government }\end{array}$ & $\begin{array}{l}\text { "When I looked at government policy, they wanted to } \\
\text { local government." } \\
\text { "...Currently, the military-installed government } \\
\text { empowered procurement authority to village headman to } \\
\text { manage the construction project without the supervision of } \\
\text { municipal construction staff." }\end{array}$
\end{tabular}


...we had close relationship and they [central government] were easily approachable. Nowadays, government officials don 't recognize us. "

- Hierarchical interactions in

"Those central authorities then ordered Ministry of internal governance settings Interior. After that the Ministry of Interior delivered an order to provincial and district authorities. The districts then ordered local governments."

"... when we have a provincial meeting. The chair of the meeting is from Ministry of Interior. The Governor is a representative from central government."

"This person (Chief District Officer) has authority to sign and approve our municipal budget."

Source: Samples of key responses in this table are selected from quotes from full interviews.

\section{Decreased Trust and Communication between Central and Local government}

Since Thailand's ongoing political crisis began in 2006, participants observed that the administrative processes governed by the national government, especially the military-installed governments, did not engage local authorities in some public service provisions and policy processes. Thus, these processes became more centralized and less accountable to local residents. In addition, the national government preferred ordering the central and provincial authorities to complete their projects as fast as they could, resulting in poor quality of the delivered projects. Its effects resulted in decreasing trust and communication between national and local government. Regarding this point, some participants expressed these perspectives:

"When I looked at government policy, they wanted to directly connect to local citizens without any influence of local government. Those duties look similar to what we usually do but they wanted to change responsible organizations from municipalities to the district, sub-district headman, or village headman (provincial authorities). In reality, the corruption still exists. It just becomes less accountable." (Member of municipal council, personal communication, August 25, 2016)

“...The things like this we [municipal council] have to check and debate for finding the best solution and decision. The municipal executive members have to answer 
and clarify those questions raised by the council members. The meeting minutes have to report to the provincial governor for review. That happened like this but what they [central government] do we cannot check or investigate." (Member of municipal council, personal communication, August 24, 2016)

"...Currently, the military-installed government empowered the village headman with procurement authority to manage the construction project without the supervision of municipal construction staff. Government wanted them to run projects by themselves. A community committee was appointed from local residents in order to investigate the projects. My question is whether there is anyone to be responsible for the projects? Is there anyone? Normally, if the municipality is responsible for the projects, we have municipal regulations to control that, such as road construction projects..." (Member of municipal council, personal communication, August 30, 2016)

Interaction between the national and local governments is an important mechanism for building effective local governance and local service delivery. In a strong, democratic society, government and local society-e.g. local government including local political actors and local residents - exist within a dynamic and interactive relationship in order to fairly share power. The boundaries between central government and local societal actors were somewhat blurred but interdependent. National and local governments cooperated with each other mutually and horizontally. In addition, authority was not one sided, as we believed that while the national government has greater authority than the local, both sides can also influence each other (Kooiman, 2003).

Since 2006, the degree of interaction between the national government and local societal actors has decreased, especially during the administration of the militaryinstalled government. Some participants mentioned that military governments imposed special laws, for instance, martial law or Section 44 of the Interim Constitution, to 
monitor and push pressure on local governments. This caused uncertainties and fears for local administrators and local residents, limiting the interactive relationship between local and national governmental agencies and actors. Regarding this point, some participants expressed that:

"It changed a lot. In the past, we had close relationship and they [central government] were easily approachable. Nowadays, government officials don't recognize us. It seems to be far away, even though we stay close." (Member of municipal council, personal communication, August 25, 2016)

"People are afraid of prohibitions, for example, since the military coup, people are not allowed to politically gather more than four people. People respect the rule because of fears and anxieties. In the recent coup, people fear the rules and orders of the military-installed government." (Municipal councilor, personal communication, August 25, 2016)

In addition, the military-installed government used direct orders to control local governments and citizens. This interactive pattern appears overwhelmingly vertical rather than horizontal. Societal actors at the local level have less power to bargain with central government, such as the national government and the national legislative assembly, due to the abolition of nationally-elected legislators. Moreover, those former elected legislators and other political institutions have been prohibited from politically connecting with their constituencies. Since 2006, the power of the national government was primarily shared only with provincial authorities, a branch of the central ministries, rather than local governments. Local governments and local citizens lacked any sort of buffering mechanism to protect themselves from the consolidation of power in the central government. Its effects clearly resulted in reducing trust and communication between two 
levels of governmental authorities. Eventually, losing trust and communication among public sectors caused ineffective public service provision. The participants shared their views on this issue:

"Currently the legislators are constrained by laws and regulations imposed by the military-installed government. They were not allowed to do any political activity or even meet with their constituents. How could they know the needs and problems of people in the communities? Was government afraid that they would pursue political gains? Actually, the MPs should be allowed to meet and ask people what they needed and what were their problems. " (Member of municipal council, personal communication, August 25, 2016)

"It affected a lot. People were happy with the past elected governments because they received new things from government policy that addressed and responded to their needs. In recent years, some important budgets, as people used to have, were cut, such as healthcare policy and community loan programs. The patterns of policies and programs were changed, even though those policies look similar, they are not. One example was the budget for stimulating the economy. The original aim was to help local people in creating business activities within their community. In reality, they did not get benefits from this policy." (Member of municipal council, personal communication, August 25, 2016)

The national political crisis caused not only an institutional breakdown, but also served as one of the critical factors disrupting the implementation of central government policies. Although, municipalities retain some small degree of autonomy in designing and implementing their own policies and in providing services that are empowered by the central government, they nonetheless required a clear policy direction from central government. Due to institutional breakdown, both national politics and policy were turbulent and municipalities began to distrust the central government's policy direction. As one interviewee said, losing confidence in the central government affected political 
involvement as witnessed during the recent Thai constitutional referendum. Only 40-50\%

of qualified voters cast a vote. Participants observed:

"My question is if they wanted to terminate the economy? Because they already approved some government projects but they ordered us to stop them. Their policies were discontinued. So that discontinuity caused trouble to the country. We cannot continue to go forward." (Local resident, personal communication, August 31, 2016)

"In the past, municipalities were flexible and government was not strict on this regulation. Previous governments were not too strict on the things that aimed to facilitate municipal affairs or supported the communities. The current government is very strict so that the municipal bureaucrats are afraid of acting in noncompliance." (Member of municipal council, personal communication, August 30, 2016)

\section{Hierarchical Interactions in Internal Governance Settings}

Participants noted that in the midst of the national political crisis, the absolute power of the military-installed government enforced specific directives on local governments. The hierarchical structure and bureaucratic governance at the national and provincial levels increasingly influenced municipal governing processes. This influence undermined the responsiveness of local governments that needed some degree of autonomy to cope with local issues and provide local public services in their communities.

The increase of power in the central government and provincial administrative authorities entailed not only the return of a staunch hierarchical administration, but also the erosion of accountability. This means that local governments are placed in a difficult position to be able to perform their jobs as usual, even though they had been providing 
these services prior to the military coups. The national government interacted with local governments by using a top-down administrative approach. Some duties (e.g. infrastructure development projects in local areas) initially operated by local governments were recentralized and operated by national and provincial administrative organizations. Some participants expressed that:

"These things are ordered by central government. The government directed central ministries and central departments. Those central authorities then ordered the Ministry of Interior. After that, the Ministry of Interior delivered an order to provincial and district authorities. The districts then ordered local governments. This is the pattern of their work." (Municipal mayor, personal communication, August 24, 2016)

"The problem is that who will do that duty. Today, I can tell you who will do that. I can tell that they wanted the District Chief Officer to do that. Because of what? I can tell when we have a provincial meeting. The chair of the meeting is from Ministry of Interior. The Governor is a representative from central government. Who sits beside him, you know? Medical doctor, civil engineer...." (Municipal mayor, personal communication, August 24, 2016)

The reintroduction of this hierarchical structure of government eroded any sense of accountability in the local citizenry. In some cases, municipal administrators seemed to listen to the direct orders of national and provincial authorities rather than recognize the legitimate power of their citizens. Municipalities tried to maintain good relationships with upper levels in order to balance their bargaining power while pursuing mutual interests. In some sense, we could consider this capacity as an opportunity; however, it is more likely that this relationship channels other forms of corruption and non-compliance, creating a threat to local governance. 
This happened because municipalities tried to avoid confrontation with higher authorities, which had renewed influence on decision-making at the local level. For example, one municipality maintained their political relationship with the District Chief Officer and the Provincial Governor. The municipality offered a series of favors to these offices in exchange for the passage of a local expenditure bill because the Governor of province and the District Chief Officer now influenced the approval of all local budgets. Regarding this point, a member of a municipal council said:

“...The district also requested financial support from us to organize Sport Promotion for Anti-Drugs. We cannot say no to that request because municipal administrators told us that the Chief District Officer requested that support. This person [Chief District Officer] has authority to sign and approve our municipal budget." (Member of municipal council, personal communication, August 30, 2016)

In addition, the participants mentioned that the effect of the political crisis increased national and provincial interventions into local autonomy. The top-down and hierarchical patterns remained existing in the administrative system. The role of provincial administrative bureaucrats was influential, but they did not concern themselves with local development. Those government officials appear to value their own promotion and job progress over concerns about the development of local communities. However, local governments have to recognize them because their authority remains powerful and beneficial for local administration. One of the participants reflected that:

"I understand them [provincial administrative officers]. They do for themselves because they want to get promotions and progression in their career path from Deputy Governor to Governor. This is what they do for themselves. Is it beneficial 
for local people, is it touchable? When you come, you come only four years. Then, you're gone. I saw and had experiences with almost ten District Chief Officers." (Municipal mayor, personal communication, August 24, 2016)

Moreover, local operational autonomy at local levels was redistributed to national and provincial authorities, thereby recentralizing power. Central ministries and provincial administrative units became more powerful while local governments floundered. It is not difficult to explain this phenomenon as the history of Thai governmental structure is one that evolved around the hierarchical power of the central authority down to the local governmental entities. That said, this study found an increase in collaboration between local governments during the political crisis, a point for discussion in Chapter 5.

Regarding the increase of hierarchical interactions, some participants addressed that problem:

"...My question is who is responsible for this project? Normally, when local government is responsible for this kind of project, we have our own regulations, such as an annual plan to build roads. We also have processes for checks and balances. For the project operation, we have professional staff to take care of that. They have to check it carefully. They have to take responsibility if there are mistakes." (Member of municipal council, personal communication, August 30, 2016)

"The limitation of local government is the slow progress of decentralization. If they fully decentralize human resources or money to local governments for example, the system will be perfectly functional. Public service delivery would be more effective. If human resources and money were fully decentralized, that would be responsive to the needs of local people..." (Municipal official, personal communication, August 24, 2016)

The national political crisis created threats to governance not only at the local level, but also resulted in declining political economy. Economic and social weakening then 
undermined local revenues and social trust in one's community. The next section describes how the national political crisis undermined political economy

\section{Political Economy}

The main debates in the literature on political economy argue that political economy is the interdependent mechanism between politics and economy. Once one mechanism (e.g. politics) is disrupted, the effects could impact other mechanisms (e.g. economy). This interaction is useful to explain the effects of political crisis on economic status as a moderating variable to public service delivery (Arndt, 1983). The political economy has two facets. First is that the internal political economy consists of an internal economic mechanism (the processes and structure of economy) and an internal political mechanism (the political structure and institutions). In addition, the external political economy includes an external economic mechanism (economic environment) and an external political mechanism (e.g. intergovernmental relations, interest groups) (Arndt, 1983; Stern \& Reve, 1980; Wamsley \& Zald, 1973). These two aspects of political economy interact with one another. It is important to note that the interactions between politics and economy cannot be separated from each other (Stern \& Reve, 1980).

The prolonged national political crisis in Thailand had a detrimental effect on political economy at the local level. Its effects resulted in low investment and a production decline in local communities. This eventually decreased local revenue collection and affected local public service delivery. In order to explore how the national political crisis brought about negative effects on political economy as a mediated 
mechanism to local public service, the participants were guided by the interview questions (see Appendix C). Based on the participants' comments, the national political crisis entailed particular threats for political economy in three ways: output decline, revenue decline, and household financial weakening. These findings are summarized in Table 4.5.

Table 4.5 Themes and Samples of Keys Responses on Political Economy

\begin{tabular}{|c|c|}
\hline Themes & Samples of Key Responses \\
\hline - Output decline & $\begin{array}{l}\text { "People don't have income as usual." } \\
\text { “...In harvest season, the current government } \\
\text { stopped helping people on the rice pledging policy } \\
\text { but local farmers already invested more than 1,000 } \\
\text { baht per rai." } \\
\text { "My wife runs a grocery store business; she said } \\
\text { her business was not good. She observed that local } \\
\text { people seem to have a decline in consumption." }\end{array}$ \\
\hline - Revenue decline & $\begin{array}{l}\text { "Opening a new shop during this time is not a } \\
\text { good idea due to the economic status." } \\
\text { "The big investors can easily run their } \\
\text { businesses but the small enterprises (household } \\
\text { level) closed down their businesses." }\end{array}$ \\
\hline - Household financial weakening & $\begin{array}{l}\text { "Our household debt has increased compared to } \\
\text { the past." } \\
\text { "My debts highly increases because of the failure } \\
\text { of growing rice." }\end{array}$ \\
\hline
\end{tabular}

Source: Samples of key responses in this table are selected from quotes from full interviews.

\section{Output Decline}

The national political crisis resulted in a demonstrable economic turndown, not only at the level of the national economy but also at local levels, undermining the progress of the local political economy. The political crisis also caused a negative impact on the relationship between politics and the economy. In the post-2006 national political crisis, the main social policies created by elected governments were suspended and some 
programs were terminated. This situation created uncertainties and fears, triggering the decline of the local economy. The local economy is considered a dynamic system where one factor (politics) interacts with another (economics).

Even though the crisis induced economic weakening at the local level, some types of businesses (e.g. franchise department stores) continued to run their businesses because they have higher financial capacity than the local small and medium enterprises. Hence, local entrepreneurs were careful when investing in local businesses. Small and medium enterprises are the mechanisms that help strengthen local economies, but fears and uncertainties caused by the political crisis made these people reluctant to increase their investments. In addition, the decline of the political economy caused hesitation in the local people to spend money for buying goods. This reluctance to purchase resulted in a decrease of available money within local communities. Regarding this point, some participants mentioned that:

"The current economy has been slowing down and is unpredictable, so that local people have been waiting for change. It looks like local people don't want to invest in some businesses. We are talking about the local area. But the external investors, such as Big C and Lotus department stores, have capacity to run their businesses because they have a lot of money to invest. It's different when we talk about local people; they fear to invest and to do businesses with just a little money like 100,000, 200,000 or 300,000 baht. They don't have too much money. In addition, they are concerned and uncertain about the market and customers. They are afraid of the return and who will buy their goods. Where do local people make their money from?" (Municipal official, personal communication, August 24, 2016)

"It affected us directly. It triggered a domino effect. Ten years ago, we paid 15 baht for a bowl of Chinese noodle soup, nowadays in [the local] area we pay 80 
baht for a similar bowl of Chinese noodle soup." (Local resident, personal communication, August 31, 2016)

In some municipalities, local people complained about paying property taxes. The effects of the national political crisis caused a decline in personal income resulting in decreasing personal income tax payments. The economic weakening during the political transition created uncertainties within the local community. Therefore, as mentioned earlier, local enterprises and local people were very careful about spending their money. Local people unfavorably compared the economic situation under the current political regime with the previously elected government. In the normal political situation, policy and political stability induced economic growth. Local people were satisfied with their stable revenues because local businesses performed well. People did not complain about paying their taxes. Regarding this issue, some participants expressed that:

"During this time, people complained about paying tax and they didn't want to spend money, especially in the transition of a political regime. It differs from Thaksin's government. People were very happy and it was an economic boom! After that, people complained about paying tax but we have to pay as we expected. We paid tax during Thaksin's regime; people didn't complain much because of economic growth. People can sell everything. It was so good for doing business. Then they had money to pay tax. They didn't complain and negotiate about tax." (Municipal official, personal communication, August 24, 2016)

“...Wherever I went, I heard people complain about economic constraints. It's difficult for them to make any money. It also affected me. My wife runs a grocery store business; she said her business was not good. She observed a decline of consumption. It looks like people work but they did not earn sufficient income. When people have less money to spend, it caused the decline of money to spend in our local community." (Municipal councilor, personal communication, August $25,2016)$ 
In addition, the national political crisis caused changes in the national policies. Some major social policies initiated by the previously elected government were suspended or even terminated, such as the rice pledging policy ${ }^{9}$. These changes also created a negative impact on the price of other agricultural products such as rubber. Local people invested a lot of money into growing rice and producing a wide-array of agricultural products. Certainly, people expected to gain greater benefits from the government's policies. The political crisis caused government and legislative dissolution that resulted in negative changes in how previous government policies were implemented. Immediate change in politics led to an associated change in policy. As a result, the price of and market for agricultural products dropped. The change undermined the economic output of local communities. The participants shared some experiences that occurred in their local communities:

"...In harvest season, the current government stopped helping people through the rice pledging policy but local farmers had already invested more than 1,000 baht per rai. To solve this problem, the farmers tried to sell it at a low price. They, themselves, sold it at about 5,000-6,000 baht, while the investment cost had already reached almost 5,000-6,000 baht per rai ${ }^{10}$. In addition, they have to pay for hiring the harvesters, right?" (Local resident, personal communication, August 31, 2016)

"People don't have the usual income. For example, in the past they can sell rubber at about 70-80 baht per kilogram, but nowadays it is just 20 or 30 baht per kilogram. They cannot run this business profitably anymore. The solution was just to cut the rubber trees because they cannot hire the labors for tapping the rubber trees. The price was in decline. All money went into the hands of traders.

\footnotetext{
${ }^{9} \mathrm{http} / / / \mathrm{www}$. loc.gov/law/foreign-news/article/thailand-crisis-in-thai-rice-pledging-scheme/

${ }^{10}$ A Thai unit of measurement equal to 1600 sq. meters.
} 
Local people began to cut the rubber trees". (Member of municipal council, personal communication, August 24, 2016)

The national political crisis created a negative impact not only for the political economy at the local level, but it also weakened revenues in local communities. The following section describes how the national political crisis created threats to these activities.

\section{Revenue Decline}

It is important to make clear at the outset that local self-collected revenue data was employed as one of the criteria for case selection as described in Chapter 3. It also serves as a proxy measure for local government performance. Therefore, a decline in revenue, in this sense, is seen as an impact that was influenced by political economy, one of the five moderating variables.

Policy discontinuity and political instability triggered weakening business activities at the local level, especially concerning agricultural and local small and medium business enterprises (SMEs). In this section, the participants emphasize that the political crisis made people less willing to invest in and expand businesses. Even though the big investors were able to maintain their businesses, most local SMEs slowed or even closed down. In some cases, the weakening economy caused by the political crisis increased the risk of declining tax revenue, especially from SMEs. Regarding this issue, some participants stated that:

"Opening a shop during this time is not a good idea due to the economic status. The economic and commercial activities within [the local] Municipality area are 
not good. People mostly sell chicken BBQ and that is $O K$ for them. When we look at the construction and appliance shops, it appears that their businesses are not good..." (Municipal mayor, personal communication, August 30, 2016)

“... most businesses have to close down.” (Municipal official, personal communication, August 24, 2016)

"The big investors can easily run their businesses but the small enterprises (household level) closed down their businesses." (Local resident, personal communication, August 31, 2016)

The effects of changes in government policy created economic uncertainties and fears. As a result, the price of goods in local markets increased, resulting in reduced buying power on the part of local residents. Consequently, these changes negatively affected business activities in local communities. Some local shops encountered difficulty in running their businesses. Some of them reduced their business scale, while others closed down, especially local manufacturing. Moreover, some participants mentioned that when the price of local products increased, cheap agricultural products that were illegally imported from neighboring countries took over local markets, undermining them. The participants shared some evidence of business activities within their local communities that were affected by political crisis as follows:

"Actually, it has large effects because the impact of the rice pledging policy created by the previous government generated high incomes for local residents. They had money for shopping and buying things in our municipal area. The local shops and department stores earned a lot of benefits from their businesses. Then, the business sectors had the capacity to pay tax. So that they would not complain like. 'Oh...the economy turns down!'”' (Municipal official, personal communication, August 24, 2016) 
"For agricultural products, the limes were so expensive in the past, right? So, our community grew them by ourselves and sold them within our community.

Nowadays, they bring the limes in the van [from Laos]. They took the seats out and put in bags of limes instead. They brought them through Thailand border and sold them at a very cheap price. The green and red onions were also moved across the border. Those agricultural products took over the Thai domestic products. Hence, what happened to the farmers? What should they do? They cannot sell their local products." (Local resident, personal communication, August 31, 2016)

"We used to have a garment manufacturer in our community. It closed for long time because of the effect of the economic downturn and the increase of minimum wage policy. This business was operated by foreign investors. Their business got affected since the minimum wage increased. Consequently, they closed and moved to a neighboring country. In addition, after the opening of ASEAN community, it caused a negative effect to our country." (Local resident, personal communication, August 25, 2016)

The economic downturn created a domino effect resulting in the decline of business activities. Some local entrepreneurs reduced labor costs by hiring cheap, undocumented laborers from neighboring countries such as Laos, Myanmar, and Vietnam, instead of hiring local laborers. The increase of illegal laborers caused not only a job crisis for local people, but also increased disease transmission and the rise of unregistered and illegal migrants. Even though only a few participants from one municipality mentioned these points, they are important to address in order to illustrate the dynamic effect regarding business activities during the national political crisis:

"You can see there are a lot of Cambodians working in gas stations. They (Thai employers) don't like to hire Thai employees. The foreign employees work harder and are cheaper than local employees." (Local resident, personal communication, August 31, 2016)

"We're concerned about public health since the ASEAN community boundary has been opened. Some neighboring countries, such as Myanmar and Laos, do not have a good health service system like us. They could have disease when they 
come. Most of them are Burmese. I saw a lot of them in [this] province that made me afraid of that." (Local resident, personal communication, August 31, 2016)

The decline of business activities at the local level caused by the national political crisis demonstrates the interactions between politics and socioeconomic conditions. The effects of the crisis discouraged local entrepreneurs from investing in and expanding their businesses. Its effects resulted in not only revenue decline in business but also household financial weakening.

\section{Household Financial Weakening}

Turbulent economic conditions caused by the national political crisis increased personal and household debt. The declining of local business activities and the suspension of important economic policies contributed to household financial weakening. In order to maintain their lifestyles during this time of crisis, local people participated in loan programs from government and private money lending institutions. Some households and enterprises incurred debt by borrowing from illegal money-lending operations. Initially, local people tried to find jobs or invest in businesses within their communities in order to cover their daily expenses, including debt repayments. However, current economic conditions did not allow them to do so successfully. The participants expressed their regard for this point as follows:

"In the current situation, I cannot get money back from people who've borrowed from me. Some people borrowed things from my shop, but they've not paid me back yet. The rubber price, rice production, and so on is declining. All trading activities have been constrained. Either legal or illegal money lending has been spreading over all local communities. In the past, during previous elected governments, people did have debts. They [the government] helped us to eliminate the debts. I 
can say a baby was born without debt. Whereas, nowadays a baby has debt since he or she was born." (Local resident, personal communication, August 24, 2016)

"Our household debt has increased compared to the past. Some people have a salary of only 1,000 baht. They can buy a motorcycle because they can pay in installments. That's right. However, they have to pay 3,000 baht monthly not only for the motorcycle, but also Internet and telephone bill. All the money is gone! Their monthly income equals their monthly expenses." (Local resident, personal communication, August 31, 2016)

"My debts greatly increased because of the failure of growing rice. Due to the drought, we cannot grow rice. We also lost money from doing farming. The cost of producing rice went up, while the market price considerably declined." (Municipal official, personal communication, August 30, 2016)

All the themes described above present the negative effects of the national political crisis on local public service delivery mitigated by five moderating variables. These patterns were shared by the participants from four municipalities through in-depth interviews and focus group discussions. In this chapter, the data gained from various participants within different municipalities provided us with an understanding of how the national political crisis created threats to local public service delivery. The following section illustrates the comparative characteristics of case performance that are analyzed across four cases.

\section{Comparison of the High- and Low-Performance Cases in Dealing with the Threats Resulting from the National Political Crisis}

Case performance analysis provides an explanation of how four selected cases, which are categorized into two groups (two high-performance cases and two lowperformance cases), matter in this study. This analysis aims to map out the characteristics 
of two types of cases through five moderating variables: political institutions, civic engagement, leadership, governance, and political economy. Local performance in this study was measured by the rate of change in revenue between 2009 and $2015^{11}$ of each municipality under study. Again, it is important to emphasize that in this study, local revenue is considered a proxy measurement of local economic performance. In analyzing threats in this chapter, it is noted that both the high and low performers experienced declines in their revenue. This implies that comparing them on the degrees of threats they experienced would be a tautology. Therefore, this study will not try to compare the level threat in this measurement between the high and low performers.

This analysis explores what characteristics of these cases minimize this threat. At the beginning, this analysis employed "categorical aggregation" to explore the collective patterns that emerged from the interview data that have related interpretations (Stake, 1995, p. 74). In addition, the patterns were categorized across two sets of cases (highperformance cases and low-performance cases) by using "cross-case synthesis" (Yin, 2014, p. 164). This form of analysis helps map out the similarities and differences of characteristics between two groups (Yin, 2014). The cases indicated the same or different characteristics through the five analytical dimensions. Then, those emerging

\footnotetext{
11 The formal data sources provided by the Department of Local Administration are available in the system from years 2009 through 2015. Some missing and updated data were collected from each municipality via telephone and annual reports provided on the municipal websites. Research case selection was described in Chapter 3: Data and Methods.
} 
characteristics help answer the questions concerning high-performance cases versus low-

performance cases.

In Table 4.6, the key findings are summarized in order to illustrate the characteristics of each group. Then, the analysis provides some explanation on the similarities or differences between high- and low-performance cases through each moderating variable.

Table 4.6 Case Performance Analysis (Threats)

\begin{tabular}{|c|c|c|c|}
\hline $\begin{array}{c}\text { Moderating } \\
\text { Variables }\end{array}$ & $\begin{array}{c}\text { High Performance } \\
\text { (What characteristics of high- } \\
\text { performance cases minimize } \\
\text { this threat?) }\end{array}$ & $\begin{array}{c}\text { Low Performance } \\
\text { (What characteristics of } \\
\text { low-performance cases } \\
\text { inability or failure to } \\
\text { minimize this threat?) }\end{array}$ & Same/Different \\
\hline $\begin{array}{c}\text { Political } \\
\text { Institutions }\end{array}$ & $\begin{array}{l}\text { - Maintained inter- } \\
\text { institutional relationships, } \\
\text { but not extremely reliant } \\
\text { upon central political } \\
\text { institutions } \\
\text { - } \\
\text { Positioned in political } \\
\text { neutrality } \\
\text { - Maintained partnership and } \\
\text { network with non- } \\
\text { governmental alliance for } \\
\text { balancing and bargaining } \\
\text { political power } \\
\text { - Kept policy alignment } \\
\text { - Open for institutional } \\
\text { interactions and feedback } \\
\text { from actors and society } \\
\end{array}$ & $\begin{array}{l}\text { - Central government } \\
\text { dependency on fiscal } \\
\text { subsidy } \\
\text { - Stagnant fears and } \\
\text { uncertainties } \\
\text { regarding limitation } \\
\text { of political } \\
\text { institutions }\end{array}$ & Different \\
\hline $\begin{array}{c}\text { Civic } \\
\text { Engagement }\end{array}$ & $\begin{array}{l}\text { Same Characteristics } \\
\text { - } \\
\text { Political fears and } \\
\text { uncertainties } \\
\text { - Political exhaustion and } \\
\text { ignorance }\end{array}$ & $\begin{array}{l}\text { Same Characteristics } \\
\text { Political fears and } \\
\text { uncertainties } \\
\text { - } \begin{array}{l}\text { Political exhaustion } \\
\text { and ignorance }\end{array}\end{array}$ & $\begin{array}{l}\quad \text { Same } \\
\text { (Local citizens } \\
\text { remain engaged } \\
\text { in nonpolitical } \\
\text { activities, but } \\
\text { still have small } \\
\text { concerns. High- } \\
\text { performance } \\
\text { cases were less } \\
\text { likely to }\end{array}$ \\
\hline
\end{tabular}




\begin{tabular}{|c|c|c|c|}
\hline & & & $\begin{array}{l}\text { minimize this } \\
\text { threat.) }\end{array}$ \\
\hline $\begin{array}{c}\text { Political } \\
\text { Leadership }\end{array}$ & $\begin{array}{ll}\text { Same Characteristics } \\
\text { - } & \text { Responsiveness } \\
\text { - } & \text { Maintained problem- } \\
\text { solving capacity } \\
\text { - } \quad \text { Valued collective decision } \\
\text { making } \\
\text { - } \text { Open for gaining feedback } \\
\text { - } \quad \text { Inter-coordination and } \\
\text { resource seeking capacity } \\
\text { - } \quad \begin{array}{l}\text { Prioritized public interests } \\
\text { but still maintained internal }\end{array} \\
\text { administrative capacity } \\
\text { Same Level but Different } \\
\text { Characteristics } \\
\text { - } \quad \text { Maintained tight } \\
\text { partnership with local } \\
\text { citizens }\end{array}$ & $\begin{array}{ll}\text { Same Characteristics } \\
\text { - } & \text { Responsiveness } \\
\text { - } & \text { Maintained problem- } \\
\text { solving capacity } \\
\text { - Valued collective } \\
\text { decision making } \\
\text { - Open for gaining } \\
\text { feedback } \\
\text { - Inter-coordination } \\
\text { and resource seeking } \\
\text { capacity } \\
\text { - Prioritized public } \\
\text { interests but still } \\
\text { maintained internal } \\
\text { administrative } \\
\text { capacity } \\
\text { Same Level but } \\
\text { Different Characteristics } \\
\text { - Flexibility and open } \\
\text { for any possible } \\
\text { opportunity }\end{array}$ & $\begin{array}{l}\quad \text { Same } \\
\text { (Low- } \\
\text { performance } \\
\text { cases were able } \\
\text { to minimize this } \\
\text { threat as high- } \\
\text { performance } \\
\text { cases did.) }\end{array}$ \\
\hline Governance & 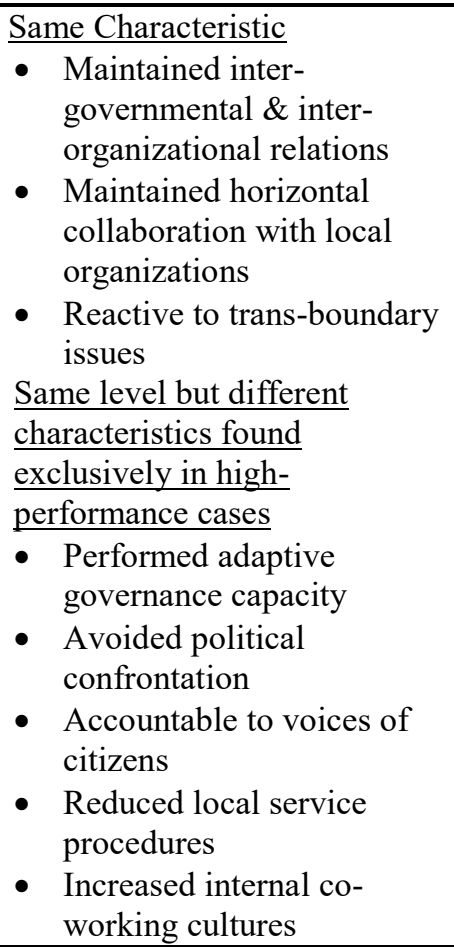 & $\begin{array}{ll}\text { Same Characteristics } \\
\text { - } & \text { Maintained inter- } \\
\text { governmental \& } \\
\text { inter-organizational } \\
\text { relations } \\
\text { - } \\
\text { Maintained } \\
\text { horizontal } \\
\text { collaboration with } \\
\text { local organizations } \\
\text { - } \\
\text { Reactive to trans- } \\
\text { boundary issues }\end{array}$ & $\begin{array}{l}\quad \text { Same } \\
\text { (Low- } \\
\text { performance } \\
\text { cases were able } \\
\text { to minimize this } \\
\text { threat as high- } \\
\text { performance } \\
\text { cases did.) }\end{array}$ \\
\hline
\end{tabular}




\begin{tabular}{|c|c|c|c|}
\hline $\begin{array}{l}\text { Political } \\
\text { Economy }\end{array}$ & 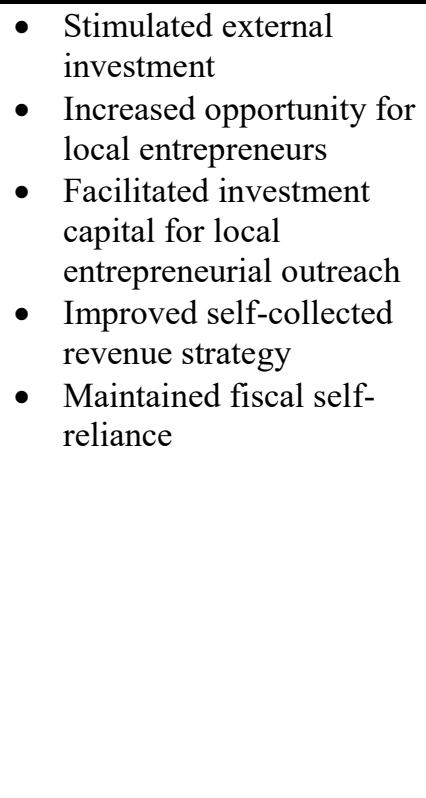 & $\begin{array}{l}\text { Absence of fiscal } \\
\text { and economic } \\
\text { strategy }\end{array}$ & $\begin{array}{l}\quad \text { Different } \\
\text { (Low- } \\
\text { performance } \\
\text { cases merely } \\
\text { addressed } \\
\text { economic } \\
\text { weakening in } \\
\text { their local } \\
\text { communities; } \\
\text { however, this } \\
\text { analysis did not } \\
\text { find any } \\
\text { significant } \\
\text { characteristic } \\
\text { that indicated } \\
\text { inability or } \\
\text { failure of local } \\
\text { governments to } \\
\text { minimize this } \\
\text { threat.) }\end{array}$ \\
\hline
\end{tabular}

Table 4.6 provides an explanation of characteristics found in both high- and lowperformances cases. The prominent characteristics were identified and summarized through the five moderating variables. The case performance analysis in this study can be explained as follows:

Political Institutions. During Thailand's post-2006 national political crisis, the relationship between national political institutions and local governments has declined, especially the weakened electoral mechanism and the suspension of local autonomy. Nevertheless, the high-performance local governments were able to minimize threats caused by the national political crisis. They were able to maintain institutional relationships between national and local political institutions. In addition, their local policies were aligned with the policies of the national government and central ministries. This policy alignment positively impacted grant subsidies. 
Although, local governments inevitably began to turn away from the political sphere, the high-performance cases placed themselves in a state of political neutrality in order to avoid direct political effects that may arise after political institutional changes. The high-performance cases utilized networking mechanisms through the National Municipal League of Thailand to help bargain and balance power in relation to national political institutions. Most of Thailand's municipalities are members of this organization. To maintain institutional value and trust, they provide easily accessible channels for local citizens to interact with local political institutions and to receive institutional feedback.

The characteristic institutional dimensions of the low-performance cases performed slightly differently from the high-performance cases. Although, the relationship between national political institutions and local governments has declined in the current political crisis, it generated threats to both the high- and the low-performance cases. It was essential to maintain relationships and take opportunities to improve local autonomy; however, low-performance cases failed to do this. They were more likely to rely on fiscal subsidies from the central government rather than improved organizational autonomy. In addition, they were fearful about institutional constraints, especially regarding legal constraints and acts of non-compliance. Political fears and uncertainties limited their capacity to cope with threats caused by the national political crisis. Based on the different characteristics of the high- and low-performance cases as described above, the low-performance cases failed to minimize threats as much as the high-performance cases. 
Civic Engagement. Although, local citizens in both categories remain engaged in nonpolitical activities held by local governments, they still have concerns. Based on case performance analysis, civic participation remains weakened and it may negatively affect other forms of civic engagement. To cope with this threat, both high-performance cases and low-performance cases suffered from similar conditions. High-performance cases rarely minimized political fears and uncertainties, reducing civic engagement. In these contexts, local citizens avoided talking about politics. Fears, uncertainties, and constraints caused by the national political crisis became critical factors that induced political exhaustion and political ignorance within civil society. Its effects weakened policy networks between local governments and societal actors. This seemed to be far beyond these local governments' capacity to minimize this threat.

For low-performance cases, this analysis similarly indicated that political fear and uncertainties limited motivation as well as the capacity of local governments to minimize this threat. Fears and uncertainties caused by political and legal constraints created barriers to local innovation. Local people were less likely to express their voices regarding politics as the political crisis caused conflict within civil society. Local governments were less likely to perform their roles as mediators for resolving conflicts among local citizens. Both high- and low-performance cases encountered difficulties minimizing this threat.

Political Leadership. Even though the national political crisis threatened political leadership within local governments, these governments provided a variety of responses 
that ranged in effectiveness. Based on the case performance analysis in this study, though all four cases were affected by the threat caused by political crisis, both high- and lowperformance cases were capable of maintaining political leadership. For highperformance cases, local governments worked closely with local citizens and were responsive to the needs and problems of the local community. Due to political and legal constraints, high-performance cases prioritized public interests, but still maintained legal compliance. Local leaders valued intra-organizational communication and internal feedback and consultation before making their decisions. If some issues were beyond their capacity, they were capable of asking for help from external connections to solve those basic problems.

Moreover, it is interesting to observe that low-performance cases were able to minimize this threat using the same strategies as the high-performance cases. They were still responsive to the needs of local community. In addition, they maintained their problem-solving capacity, even though they encountered political and legal constraints. They were capable of seeking financial support from external sources in order to maintain progress in local development activities. Low-performance cases valued leadership as a vital mechanism during the transitional period and local leaders valued feedback gained from frontline officers as part of collective decision-making. They prioritized solving local problems by cutting municipal administrative costs. In conclusion, both high- and low-performance cases shared similar characteristics 
demonstrating that the low-performance cases were capable of minimizing this threat as much as the high-performance cases.

Governance. Case performance analysis revealed that high-performance cases were able to minimize political threats to local governance. Local governments employed adaptive governance to deal with changes in political institutions and policies. They tried to be flexible with new governing procedures that were installed by the military government. In addition, they avoided confrontation, instead creating more collaboration with upper-level political authorities. To respond to local needs and seek collaboration, they coordinated with internal and external networks such as neighboring local governments, village headmen, provincial governmental agencies, the business sector, and the National Municipal League of Thailand. They proactively dealt with transboundary issues that might affect local communities, even though those problems or complaints did not fall under the province of their formal duties. High-performance cases were likely to listen to citizen voices and stakeholders in order to encourage robust trust and accountability. To maintain good performance of local services, they reduced municipal service procedures. This helped increase trust and service satisfaction in local citizens. Interestingly, they built co-working cultures and improved intra-organizational collaboration so that municipal officers could work across departments.

Similarly, the low-performance cases shared the same characteristics as the highperformance cases. They tried to maintain working relationships with the provincial offices of the central ministries. For example, the local governments provided their staff 
and financial support to provinces and districts when those organizations requested assistance. In addition, the low-performance cases were capable of keeping close connections with permanent officers from central government organizations, such as the Department of Local Administration, Ministry of Interior. Those organizations were important for accommodating local governments and connecting with policy makers in the central government. They also influence budget and resource allocation at the national level. Based on the data analysis, both groups of local government have the same characteristics and they are both able to minimize this threat.

Political Economy. In this analytical dimension, the high-performance cases were particularly capable of minimizing the political threats that caused economic weakening in the local community. One of the cases tried to stimulate the local economy by encouraging franchise department stores to invest in its municipal area. Even though the investors in these businesses were not local, they nonetheless helped to develop robust local economies. Additionally, local governments provided commercial spaces like small, open markets for local entrepreneurs who lacked investment capital and also helped them find funding sources by coordinating with local banking institutions to provide loans to those who lacked investment capital. High-performance cases minimized their financial constraints in the midst of the political crisis by improving tax collection strategies, helping to increase self-collected revenue. Effective tax collection did not merely impact economic factors, but also operational factors administered by municipal officers. In this vulnerable situation, the high-performance cases maintained financial 
security by employing collective decision making that included local administrators, local legislators, and municipal officers in the process.

However, this dimension was different in the low-performance cases. Both cases merely addressed economic weakening in their local communities. The analysis demonstrated an absence of fiscal and economic strategies. This assumes that the lowperformance cases lacked the ability to minimize this threat.

\section{Summary}

In conclusion, this chapter described the effects of Thailand's post-2006 national political crisis and the resulting threats to local government service delivery. The key findings were illustrated through five moderating variables in "Graphical Representation of Findings: How National Political Crisis Creates Threats to Local Government Service Delivery" (see Appendix A).

First, political institutional breakdown of local governments weakened electoral mechanisms at both national and local level. Institutional breakdown also caused the suspension of local authority policies. Then, political fears and uncertainties reduced civic participation and weakened policy network in local communities, thus increasing civil conflict. Next, the effects of national political crisis reduced autonomy of local leaders and increased risks for local leaders. Fourth, due to national political crisis, trust and communication between central and local governments have decreased, resulting in suspended decentralization and declining accountability. Also, hierarchical interactions in internal governance settings were increased. Finally, political turmoil interactively 
induced negative impacts for political economy at local level. This caused local economic output decline, revenue decline within local business sectors, and personal and household financial weakening.

In the final part of this chapter, case performance analysis identified the characteristics of high- versus low-performance cases. The analysis articulated both similar and different characteristics found in each analytical dimension. Similar characteristics were identified within the dimension of civic engagement, leadership, and governance. It is important to note that the characteristics of both high- and lowperformance cases in the civic engagement dimension are similar in their negative results; both the high- and low-performance cases failed to minimize the political threats posed to civic engagement. The high- and low-performance cases within the leadership and governance dimensions did share positive characteristics. In these dimensions, lowperformance cases were able to minimize the threat as well as the high-performance cases. Differences in characteristics were identified within the institutional and social economic dimensions. In this sense, the low-performance cases failed to minimize the threat as much as the high-performance cases.

As mentioned at the outset, Thailand's post-2006 national political crisis created not only threats, but also opportunities for development in local government service delivery. The next chapter will describe how the national political crisis created opportunities for local government service delivery through five moderating variables and case performance analysis. 


\section{Chapter 5 \\ How National Political Crisis Creates Opportunities \\ for Development in Local Government}

The previous chapter presented the effects of national political crisis that created threats to local service delivery. While the national political crisis was seen by participants as overwhelmingly negative in its impacts on local service performance, they also believed that it had created some opportunities for improvement.

In some cases, such as Thailand's institutional breakdown, threats to formal institutions, especially the existing constitution, were created. The military-installed government imposed Section 44 of the 2014 Interim Constitution to address political conflicts, eliminate certain laws, and remove certain appointed government officials from their positions. This was considered a threat to the democratic institutions and fundamental rights of Thai citizens (Forum-Asia, 2015). Nevertheless, these threats created some opportunities for facilitating local service delivery. These opportunities were embedded in the very same threats to local service performance.

In other instances, these opportunities arose separately from the threats. For example, Khoman (2005) states that Thailand's economic crisis that began in 1997 was not necessarily considered a threat but its effects triggered opportunities for boosting Thailand's political reform and stimulating government to work closely with citizens. The idea that crisis, disaster, or catastrophe can yield important opportunities for social, economic, and even political development and performance has been widely studied by scholars. 
For example, in "Antifragile; Things That Gain from Disorder, " Nassim Taleb (2012) argues that systems that respond favorably to threats are called "antifragile" (p. 31). The concept of antifragile explains the positive things as opportunities gained from turmoil or uncertainty. Threats create opportunities for building methods of prevention or solutions for the future (Taleb, 2012). In addition, Horwich (2000) proposes an economic recovery concept that was developed based on the experiences of the Kobe Earthquake of 1995. The recovery concept employs the idea of "accelerated depreciation," by which a crisis leads to a more rapid replacement and upgrading of outmoded systems (Horwich, 2000, p. 523).

In public policy perspective, Kingdon (2003) argues that change in "political stream," for example change in government and/or a change in policies, induces the opportunities for an "open policy window" (p. 168). An open policy window is an opportunity for revising or even changing policy and proposing policy initiatives. Importantly, political crisis can be a vital factor that opens a window of opportunity for rearranging political institutions (Kingdon, 2003). While crisis was seen as a negative thing, it created opportunities for youth in Africa to express their ideas regarding policy discontent, governance, and democracy. As a result, their voices were heard and became a powerful mechanism that improved their roles in the social movement (Iwilade, 2013).

\section{Results}

Thailand's post-2006 national political crisis entailed not only threats to local governments but also brought opportunities. This chapter discusses how the national 
political crisis created opportunities for local service delivery. The results are presented using the five moderating variables as the analytical framework. To substantiate the findings, pertinent quotes from the participants are presented. At the end of this chapter, as in the last chapter, the results from a comparative analysis of the low and high performers are presented.

\section{Political Institutions}

The main discussion in the literature on political institutions argues that "institutions do matter" to both individuals and organizations in civil society (Peters, 2011, p. 79; Teske, 1991). Political institutions influence political arrangements, political structure, and autonomy. The results of institutional change may create both negative and positive impacts to social interactions and behaviors as well as public local service performance (Hicken \& Selway, 2012; March \& Olsen, 1984; North, 1990; Painters, 2004; Peters, 2012). Even though crisis is generally seen as having a negative impact at the individual and organizational levels, opportunity is concealed within every crisis. Generally, a crisis provides particular opportunities to political institutional evolution and strengthens the institution-citizen relationship (Fry, 2014). For example, Thailand's political crisis in 1992 triggered positive impacts on political reform and the progress of decentralization (Khoman, 2005).

According to the participants of the study, the opportunities to political institutions created by political turmoil were described in three themes: (1) Section 44 reducing the need for a long approval process; (2) Damrongdharma Centers providing an 
outlet for local voices; and (3) Provincial Administration Organization (PAO)-local institutional capacity. The themes and key responses on political institutions are presented and summarized in Table 5.1.

Table 5.1 Themes and Samples of Key Responses on Political Institutions

\begin{tabular}{|c|c|}
\hline Themes & Samples of Key Responses \\
\hline $\begin{array}{l}\text { - Section } 44 \text { reducing the need } \\
\text { for a long approval process }\end{array}$ & $\begin{array}{l}\text { "Section } 44 \text { can order and terminate the inconvenient } \\
\text { issues or the limitations of those regulations in order to } \\
\text { facilitate our work when we want to assist people." } \\
\text { "When the current military installed government } \\
\text { enforced Section 44, the administrative system moved very } \\
\text { fast. People were satisfied on this point." }\end{array}$ \\
\hline $\begin{array}{l}\text { Damrongdharma Centers } \\
\text { providing an outlet for local } \\
\text { voices }\end{array}$ & $\begin{array}{l}\text { "Since the Damrongdharma Center was established, } \\
\text { people thought it helped them faster, so they just skipped the } \\
\text { municipal process and sent their complaints to this center." } \\
\text { "...having this center [the Damrongdharma Center] } \\
\text { made them [the local people] feel safe..." }\end{array}$ \\
\hline $\begin{array}{l}\text { - PAO-local institutional } \\
\text { capacity }\end{array}$ & $\begin{array}{l}\text { "The sun never sets [for our local network]. The sub- } \\
\text { district administration organizations and the provincial } \\
\text { administrative organization are always welcoming us. We } \\
\text { can coordinate with them anytime." } \\
\text { "Recently, the mayor asked for financial support from } \\
\text { the PAO in order to improve and develop a bigger } \\
\text { playground." }\end{array}$ \\
\hline
\end{tabular}

Source: Samples of key responses in this table are selected from quotes from full interviews.

\section{Section 44 Reducing the Need for a Long Approval Process}

Thailand's post-2006 national political crisis created particular opportunities for institutional responsiveness. Positive influences arose especially after the 2014 military coup. One of the participants noted that Section $44^{12}$ as used by the NCPO created an opportunity for administration and decision-making at the local level. Section 44 states that:

\footnotetext{
12 The Government Public Relation Department, http://thailand.prd.go.th/ewt_news.php?nid=1581\&filename=index
} 
"In the case where the Head of the National Council for Peace and Order deems necessary for the purpose of reforms in various fields, for the enhancement of unity and harmony among people in the country, or for the prevention, restraint, or suppression of any act which undermines public order or national security, the Monarchy, the national economy, or State affairs, irrespective of whether such act occurred inside or outside of the Kingdom, the Head of the National Council for Peace and Order, with the approval of the National Council for Peace and Order, shall have power to order, restrain, or perform any act, whether such act has legislative, executive, or judicial force; the orders and the acts, including the performance in compliance with such orders, shall be deemed lawful and constitutional under this Constitution, and shall be final. When those have been carried out, a report shall be submitted to the President of the National Assembly and the Prime Minister for acknowledgement without delay." (Thailand. Const. (Interim) § 44, 2014).

According to many participants, Section 44 provided a shortcut in decisionmaking and an administrative tool for local governments to serve citizens' needs and solve specific problems. In this sense, its impact was useful for local service delivery in terms of legal facilitation and responsiveness. In the past, local governments needed to gain approval from central ministries and provincial administrative authorities via many hierarchical procedures prior to providing some services or undertaking certain public projects. Section 44, when invoked by the Prime Minister, helped resolve legal and technical problems and streamlined some complicated bureaucratic processes. Nevertheless, there were many criticisms concerning the effect of using Section 44 in government administration. A major criticism was that the fast-track operation and quick decision-making may threaten accountability and transparency in both the national and local governments. Some participants described their concerns:

"Frankly speaking, I would say that in the absence of an [elected] government, when we needed something, Section 44 provided a convenience for us. It makes things easier for us. It's convenient. In the past, we had to get approval from the provincial governor or district chief officer. Section 44 can order and terminate 
the inconvenient issues or the limitations of those regulations in order to facilitate our work when we want to assist people." (Vice mayor, personal communication, August 25, 2016)

"When the current military-installed government invoked Section 44, the administrative system moved very fast. People were satisfied on this point. They like this pattern. Regarding economics, I agree that the military-installed government was incapable of handling it like the general investors. For the governmental administration, the military government performed well." (Local resident, personal communication, August 30, 2016)

According to the participants, the positive impacts of political crisis resulted not only in reducing approvals within conventional bureaucratic procedures, but also establishing formal institutional channel to receive feedback from local citizens.

\section{Damrongdharma Centers Providing an Outlet for Local Voices}

After Thailand's 2014 military coup, NCPO established nationwide government centers called Damrongdharma Centers ${ }^{13}$ as a channel to receive citizens' complaints, handle civil conflict, and manage public interests. These centers had an impact on local governments. For example, if local feedback has been given but the municipalities have not reacted to it in a timely or appropriate fashion, citizens can then send their complaints through the Damrongdharma Center located in provincial hall. At the provincial level, the military authority can intervene and immediately respond to citizen feedback. On one hand, military action may harm local government performance and credibility in terms of

\footnotetext{
13 The Damrongdharma Center was established by the National Council for Peace and Order (NCPO). The center is national wide governmental organizations. It is located in each province in Thailand and is responsible to the Ministry of Interior. The aims of this center are to represent NCPO for responding to citizen complaints on governmental services, facilitate conflict resolutions, and protect public interests (Links: http://www.mea.or.th/moi/pomc/doc/ncpo96.pdf and http://www.nationmultimedia.com/news/national/aec/30243281).
} 
problem-solving capacity and responsiveness. On the other, having this center at the provincial level increased local influence on public concerns. Importantly, military authority became one of the vital mechanisms that helped stimulate local governments to react to local problems and expand space for public participation. Some views gained from participants were:

"Since the Damrongdharma Center was established, people thought it helped them faster, so they just skipped the municipal process and sent their complaints to this center. Then, the center ordered us [the municipality] to respond to people's complaints. It created a bypass and broke the line." (Municipal councilor, personal communication, August 25, 2016)

"Yes, having this center [the Damrongdharma Center] made them [the local people] feel safe like they had the Prime Minister from military. They were courageous to speak out and present their opinions." (Municipal official, interpersonal communication, August 31, 2016)

Even though these centers are seen as political instruments of the central authorities in Bangkok, the end results satisfied local residents. Importantly, local voices were heard and responded to through this channel.

\section{PAO-Local Institution Capacity}

Since the beginning of the political crisis in 2006, many local governments lacked resources, especially money, and experienced a growing lack of autonomy. To respond to the needs of their local residents and to maintain effective local service delivery, municipal leaders coordinated with both lower and upper levels of local government as well as governmental agencies, especially the PAO. 
The national political restraints created a positive impact for building local institutional capacity. It was not necessary for local governments to wait for help from the national government. At this point, the PAO, as an upper level of local government, played an important role in assisting municipalities to maintain the quality of public service. Participants discussed this issue:

"The sun never sets [for our local network]. The sub-district administration organizations and the provincial administrative organization (PAO) are always welcoming us. We can coordinate with them anytime. We, the local government, surely can take care of each other. (Municipal councilor, personal communication, August 24, 2016)

"The PAO's legislators always contacted us. They tried to provide as much assistance as they could. We asked for help through the PAO's legislators. (Municipal councilor, personal communication, August 30, 2016)

"For educational affairs, the mayor provided a budget for taking care of children. The budget provided only for buying a small playground. Recently, the mayor asked for financial support from the PAO in order to improve and develop a bigger playground. Actually, we just signed the MOU with the PAO for childcare development. (Municipal councilor, personal communication, August 30, 2016)

\section{Civic Engagement}

The literature on civic engagement argues that civic engagement in democratic society can be seen in two forms. The first is formal civic engagement. This form emphasizes the traditional, formal political participation that involves formal institutional processes and structures such as voting, advocacy by political parties, political candidates, etc. The second form is informal civic engagement, which is more flexible. This informal form focuses on volunteer activities, cultural and religious activities, and social movements (Pahad, 2005). 
In addition, civic engagement is a positive source for enhancing democracy and effective public policy process at both national and local levels. In civic community, citizens are the main players in forming policy and designing public service (Holmes, 2011; McLaverty, 2011; Michels \& Graaf, 2010). Nevertheless, the pattern of civic engagement is seen through the status of the political institutions, especially change in political institutions. Institutional change affects suspension of electoral mechanisms and political activities. These factors influence the pattern and form of civic engagement (Dalpino, 2012; Waitoolkiata \& Chambers, 2015). Moreover, when a political institution is weak and faced with difficulties, it is not necessarily bad news for civic engagement. In this sense, Börzel and Risse (2015) argue that strong collective actions help strengthen local governance and increase trust in government.

Although citizens' political engagement with national institutions and affairs in local communities declined during the political crisis, the tightening relationship between local governments and local citizens induced some degrees of progress in civic engagement at the local level. Clearly, we have found an interesting phenomenon of two contrasting social milieu where there is decline in civic participation in political affairs at the national level, but at the same time a more active participation at the local level.

As a moderating variable, the effects of civic engagement resulted in improving local service delivery. The study found four themes in this mechanism: Increased trust in local government; increased formal (council) participation; increased informal (vocal) 
participation; and increased community building. These themes are summarized in Table

\section{2 .}

Table 5.2 Themes and Samples of Key Responses on Civic Engagement

\begin{tabular}{|c|c|}
\hline Themes & Samples of Key Responses \\
\hline - Increased trust in local government & $\begin{array}{l}\text { "Local people realized that local government is involved } \\
\text { in their life from birth to death. Local government is very } \\
\text { important to us." }\end{array}$ \\
\hline $\begin{array}{l}\text { - Increased formal (council) } \\
\text { participation }\end{array}$ & $\begin{array}{l}\text { "For the council meeting, when we [the municipal } \\
\text { legislators] debated budget cuts, local people came to listen } \\
\text { to us in order to ensure that this was not only a one-way } \\
\text { communication." }\end{array}$ \\
\hline $\begin{array}{l}\text { - } \\
\text { - } \\
\text { - } \quad \text { Increarticipation } \\
\end{array}$ & $\begin{array}{l}\text { "When local citizens attended the town hall meeting, they } \\
\text { were not afraid to speak out or perform their reactions." } \\
\text { "When our municipality held activities that are involved } \\
\text { in local tradition and culture, most civil organizations, local } \\
\text { people, youth, local leaders, monks and other religious } \\
\text { leaders actively engaged in our activities." }\end{array}$ \\
\hline
\end{tabular}

Source: Samples of key responses in this table are selected from quotes from full interviews.

\section{Increased Trust in Local Government}

In times of national political crisis, political institutional breakdown created uncertainties and threats to local governments and local citizens. Conversely, a crisis is an opportunity for local governments to work closely with their local residents in order to build trust in local government. Political fears and uncertainties caused by the national political crisis made local residents count on the local governments and vice-versa. As a result, local residents felt a greater degree of safety and comfort because local governments and local legislators stood beside them. The decline of responsiveness of the national government during the political crisis caused many local residents to increase 
their trust in the ability of local government to address problems. One of the participants stressed that:

"Local government is always beside local citizens. If they [local people] report to us about the waterworks getting stuck, we have to take care of that by coordinating with the provincial waterworks authority [not a local duty]. If a power outage occurs, we have to fix it for our people [actually, it is not a local duty]. " (Member of municipal council, personal communication, August 24, 2016)

Local residents perceived that the national government, especially the militaryinstalled government, was far away from them. The local governments were seen by the local citizens as even more easily reachable and closer than the national government. The more local residents got closer to their local government, the more trust between local citizens and local government developed. Having a high level of trust in local government induces civic participation and also increases effective engagement in local public service. Regarding this issue, the participants provided some examples:

"The local government is more functional and practical because local administrators and local legislators live within the community. They know what is going on in their community and react immediately in order to respond to the needs of local residents. The responsiveness is faster than the central government. Nowadays, if the central government or district remained responsible for local duties, it would take longer for obtaining each road... This is reflecting that if they [local residents] cannot get what they need rapidly, they will report to the top administrator...Nowadays, for every issue including, raining, flooding, stuck toilets, etc., people report to the municipality..." (Municipal officer, interpersonal communication, August 25, 2016)

"We designed and framed our policy such as infrastructure development or living improvements. We work closely with local people that we should not depend on anyone else. Whoever comes to help us, we should be flexible with them. When the municipality conducts business, we always inform people that we 
are volunteering to help. You may see before deciding to do something in our local community, we are open for civic engagement. We open the stage for everyone to share and propose their ideas. We then use these inputs to create the municipal strategic plan so that we don't encounter as many problems." (Vice mayor, personal communication, August 25, 2016)

"From my point of view, when we consider the closeness to the people of local and central political institutions, we are closer to our local government than the central government. They [local residents] said they have never even seen their faces [central legislators]. We met the central legislators only once during election season. How close are they? How can they know about local problems? But local governments are more approachable. Local people can come to the mayor directly. Even though some duties do not belong to us, for example, when the water system had problems, people thought of us and came to us. Actually, the provincial waterworks authority is not our duty." (Mayor, personal communication, August 24, 2016)

The closer relationship between local governments and local citizens in the midst

of the political crisis is not only advantageous for strengthening local political

institutional interactions but also increases trust in local governments. This change made local citizens learn about and understand the role and importance of local governments, especially the role of local government as a major public service provider within their community. Local government was vitally involved in their everyday lives from birth to death. As some participants said:

"Local people realized that local government is involved in their life from birth to death. Local government is very important to us. " (Member of municipal council, personal communication, August 24, 2016)

"Compared to the past, local citizens are more interested in local politics and local government... Nowadays, they are eager to ask questions when we have local political campaigns or when we meet with them in public. They request their rights. Sometimes, they ask us that what we can do for them if they elect us as local councilors." (Municipal councilor, personal communication, August 25, 2016) 
"People mostly think of their municipality. They primarily think of local government-i.e. local councilors or mayors. In ... Municipality, the relationship between our community and central legislators is quite low." (Municipal councilor, personal communication, August 24, 2016)

In addition, the norms of local citizens tended to change for the better when local government played a vital role in and became a part of their everyday lives. They thought of local government first when they had problems within their communities. Citizens perceive that local government could help address their needs better than other public institutions (Hall \& Taylor, 1996). Citizens realized that local government and local legislators are closer to them and respond to their needs faster than central political institutions, and that they can conveniently approach local legislators and local services. In addition, local governments tended to value the voices and power of local citizens as input for policy design and collective decision-making. Citizens became key stakeholders in policy processes and public service provisions. Regarding this point, some participants share their experiences:

“...We are never far away from the municipality. They are close to us. Currently, there are two types of political characteristics in Thailand, i.e. vertical and horizontal. People now are interested in the horizontal form that is closer to them, for example, mayors and local councilors. But the role of the vertical form is to give order to the lower levels. Hence, the relationship is quite estranged." (Local resident, interpersonal communication, August 25, 2016)

"When they [local residents] have problems, they come to the municipality. They don't go to see politicians [central legislators]. They come directly to us or sometimes they call directly to the mayor or the head of a department. They report problems to us directly by giving us a call." (Municipal official, interpersonal communication, August 24, 2016) 
"If someone's roof has holes, they come to the municipality. For flooding in our community, we need help from the municipality to provide a drainage pump. We come to municipality to report our problems. If we have wedding parties, we invite the mayor and the councilors. Everything is here. I feel like the municipality is like our parents, we depend on it." (Local resident, interpersonal communication, August 30, 2016)

"We can meet with the mayor directly whenever we have problems. Sometimes, those problems are not municipal duties. For example, the provincial waterworks authority is not under local jurisdiction. It is responsible to the provincial administration, but local people primarily think of us. They call us when there is an electric outage within their communities. We have to react and respond to these problems because they call us, even though those duties are not our responsibility..." (Mayor, personal communication, August 24, 2016)

A political crisis does not always result in a negative change in local political institutions; it can also have a positive impact on local development. The relationship between local citizens and local governments is more tightly constructed. Local citizens understand the role of local governments, while local governments prominently value and prioritize the interests and the needs of local citizens. A crisis also triggers positive change in political norms and the political value of local citizens as well as municipal officers.

Moreover, the positive impact gained from the political crisis created opportunities for local government to build local awareness and a sense of local citizenship. Local citizens increasingly cared about and were concerned with problems occurring in their communities. They attentively reacted to the issues that affected not only their individual lives but also their local society. Because of local trust, the feedback 
and concerns were frequently directed to municipalities for further improvement. Some participants addressed this issue:

"Local people are increasingly engaged in municipal activities. They were also interested in joining the activities that were organized by the municipality." (Municipal official, interpersonal communication, August 31, 2016)

"People saw the progress of their community, so that they were more concerned [about it]. For example, a mayor has worked almost four years, what about his performance? The municipality always gained the grant, but we didn't see any output. They compared the performance of this mayor to the previous mayor." (Local resident, interpersonal communication, August 25, 2016)

Civic engagement became a mechanism to generate robust dialogue between citizens and local governments, especially in times of political instability. Outwardly, the political crisis eroded the progress of political engagement. However, local governments were capable of maintaining non-political engagement and encouraging local citizens to participate in collective decision-making. Political instability stimulated local governments to provide space for gaining feedback from citizens. As this study observed, it created an opportunity for local citizens to build local awareness and improve their sense of citizenship. The following section explains how national political crisis increased formal institutional participation.

\section{Increased Formal (Council) Participation}

Participants saw the national political crisis as an opportunity for local government to attentively engage local citizens in the municipal council meetings. According to the public participation spectrum, municipal and local leaders informed local citizens that they could attend the council meeting that were routinely held in the 
municipal office. Their attendance at the council meetings suggested that they were becoming involved in decision-making processes.

Yet, based on council regulations, local citizens were not allowed to express any comments while attending the meeting. They were simply observers. This process of engagement guaranteed the citizens' right to have at least some participation in the decision-making of municipal administrative and legislative bodies. It also allowed citizens to see how their local legislators performed during the meeting sessions. These activities helped increase not only civic engagement, but also accountability and transparency in local administration. Regarding this point, some participants indicated that:

"Our municipality sent out a letter to the community committee and the community leaders in order to ask them to announce the council meeting schedule. If local residents want to attend the council meeting, they need to bring a copy of the house registration or a copy of their identification card to show municipal staff prior to the council meeting. We also explained the rules of the council meeting to the citizens, namely that they cannot debate or express any voice while attending the meeting." (Member of municipal council, personal communication, August 24, 2016)

"We were invited to attend the council meeting. We also helped them to spread the word to other local citizens that if anyone would like to attend the council meeting, they were welcome. They [the municipality] invited local citizens in each community to attend the council meetings. If council members ask us something, then we are allowed to speak out. We cannot vote in this meeting but we come to listen to them." (Local resident, interpersonal communication, August 24, 2016)

"For the council meeting, when we [the municipal legislators] debated budget cuts, local people came to listen to us in order to ensure that this was not just a one-way communication. We wanted them to know and see what happened in the council meeting. If local people do not know anything about local administration, 
we cannot work effectively." (Vice mayor, personal communication, August 25, 2016)

Moreover, local civic engagement seemingly advanced to higher levels when

local governments provided space for local citizens to give feedback and become involved in municipal decision-making. In some municipalities, local citizens were invited to serve as committee members or as members of the municipal operations team. At this stage, local citizens can express their opinions, provide feedback, and even make decisions on municipal development projects. This is not only to encourage local people to get engaged in collective decision-making but also to build trust in local governments. Participants provided their experiences regarding this point:

"When we had a town hall meeting, local citizens were actively engaged in the meeting. They shared their thoughts on development projects." (Municipal official, interpersonal communication, August 25, 2016)

"For my duties - i.e. an employee of a municipal department, if citizens propose the projects, they will be appointed to... [To be a committee member] ... They seem to be happy working with us. But if they did not know about the project or were not involved, it was useless. It's not useful and it wastes money. But if we provide projects they need, such as the debris management project, people were ready to work with us. If they don't want it, it won't happen." (Municipal official, interpersonal communication, August 24, 2016)

"People increasingly scrutinized our work. The past 10 years is totally different from the time before. When we were the Tambon Administration Organization, people were afraid of checking [the work of government]. Nowadays, people actively check government work. They know their roles very well." (Municipal official, interpersonal communication, August 31, 2016) 


\section{Increased Informal (Vocal) Participation}

The political crisis triggered opportunities that resulted in not only the improvement of formal civic engagement, but also the increase of engaging space, as informal participation, for citizen feedback and accessibility in their local community. Local people were eager to speak out in order to provide recommendations to the municipalities for improving services. Local people routinely addressed feedback to their local legislators or even came to the municipalities directly.

Some participants noted that changes in politics may not affect citizen engagement, but civic engagement may be created from the understanding and awareness that they've learned from politics. Participants provided their thoughts on this point:

"Civic engagement in the ... Municipality is very good. When we hold municipal plan meetings, they [citizens] usually bring public issues to the meeting. They engage with us very well. They like to suggest how to solve problems in the community. It seems like we receive more feedback from them." (Municipal official, interpersonal communication, August 25, 2016)

"When local citizens attended the town hall meeting, they were not afraid to speak out or voice their reactions. " (Municipal official, communication, August 31, 2016)

"In the past 10 years, local people are increasingly willing to speak out and reflect their opinions." (Member of municipal council, personal communication, August 25, 2016)

The channel to increase opportunities for civic engagement between local citizens and their governments has widened from classical approaches such as face-to-face interaction to include modern digital interaction. In the digital era, local governments employ various forms of social media to interact and engage with citizens, such as 
websites, Facebook, Line, etc. Social media has become a vital instrument for local governments to communicate with and engage citizens in times of political crisis. Important information and some municipal resources were made available to the public through municipal websites and Facebook in order to build trust and accountability. At the same time, local citizens use social media as a channel to provide feedback and follow the activities of local governments. Facebook became a practical and accessible source for maintaining civic engagement in local communities. Regarding this point, some participants indicated that:

"It is different from the past. It is related to advanced technology. This factor encouraged people to express their voices, not just stay still and keep quiet." (Local resident, interpersonal communication, August 25, 2016)

"In my opinion, local people actively engaged with local governments and they courageously expressed their views. They received news and information very fast. They also reacted to problems very quickly. Whenever they had problems, they came to see us immediately." (Municipal official, interpersonal communication, August 25, 2016)

"Local people actively engaged in local activities. When our kindergarten center held some activities, we always invited parents to join us. Parents also followed news and information from our Facebook page. In addition, if they know we punish their kids, they will call directly and send complaints to the mayor." (Municipal official, interpersonal communication, August 30, 2016)

"The impact of current mass media and social media encourages local people to quickly post and share their complaints on social media space. It spreads widely

..." (Municipal official, interpersonal communication, August 31, 2016)

\section{Increased Community Building}

The participants indicated that local residents were active in formal civic engagement and politically-related activities. During the time of the elected government, 
the central government and central legislators remained a democratic regime. Later, these political institutions were removed and replaced by the military-installed authorities, and the political sphere became tumultuous, creating fears and uncertainty for local people. Consequently, local people lacked a means of engagement in formal political activities. However, they were apparently comfortable involving themselves in non-formal civic engagement and non-political activities rather than formal civic engagement. Most activities were organized by municipalities, e.g., local festivals, traditional activities, religious activities, and town hall meetings.

Even though the political crisis remains unsettled, local residents in some municipalities were motivated to engage in local political activities such as attending council meetings or volunteering on municipal committees. Local citizens felt comfortable getting involved in such local activities. They engaged in local activities by ignoring political identity and political conflict-i.e. yellow and red identities. Hence, the municipalities utilized these opportunities to increase community-building by stimulating local civic engagement. The strong civic community helped enhance co-production in local public services. Concerning this point, some participants said:

"According to the duty and structure of the municipality, the municipal office is normally responsible for education, religion, and culture. When our municipality held activities that involve local tradition and culture, most civil organizations, local people, youth, local leaders, monks and other religious leaders actively participate in our activities. (Municipal official, interpersonal communication, August 25, 2016. 
"Local people mostly liked engaging in making merit, traditional activities, and religious activities." (Local resident, interpersonal communication, August 31, 2016)

"When our municipality held local activities that were related to local development, sports, education, or public health, local people frequently participated in our activities. They also helped us to create and develop those activities. (Municipal official, interpersonal communication, August 24, 2016)

The effects of national political crisis induced not only positive impacts to civic engagement at the local level in both formal and informal ways, but also improved the capacity of political leadership.

\section{Political Leadership}

Most of the literature on leadership argues that leaders with high leadership capacity help increase effectiveness and efficiency in public services (Wart, 2003). In addition, difficult and challenging situations require leaders who can provide vision and use their own problem-solving skills to make appropriate decisions on public service management (Fiedler, 1996; Wart, 2003). For contingency leadership, task motivated leadership style is necessary for leaders who wish to succeed in their goals, especially in difficult situations (Fiedler, 1971; Northhouse, 2010).

In crisis situations, Boin et al. (2017) argue that strategic crisis leadership should include the capacity to estimate and understand the qualities of a situation. The leaders can then make decisions and use appropriate tools in response to each crisis. In addition, leaders should have good communication skills in order to give a clear explanation and provide an understanding to their followers and associates. Importantly, crisis is not 
always a bad thing; it is embedded with opportunities. In the midst of a crisis, people expect that public leaders need to do something that can maintain public services and bring back normalcy. Once the crisis situation and the people's concerns are effectively managed and eased by leaders, this leadership achievement can elevate leaders to be heroes or "statesmen" (Boin \& "t Hart, 2003, p. 544). So, political crisis is not always bad news for leadership. Even though crisis causes change in governmental administration and policy, this sort of change creates windows of opportunity that open for revising (or even removing) policies and rearranging political institutions (Kingdon, 2003).

In the midst of political crisis, there is ultimately a political leadership opportunity for local leaders and they need to identify and respond to these opportunities. Local government leaders require leadership to mitigate and cope with political fears and uncertainties that undermined local service delivery. In this study, political leadership emphasizes municipal administrators. National political crisis creates leadership opportunities for local leaders. Its effects result in elevating the role of mayors to respond the needs of local residents. These findings are summarized in Table 5.3.

Table 5.3 Themes and Samples of Key Responses on Political Leadership

\begin{tabular}{cc}
\hline Themes & \multicolumn{1}{c}{ Samples of Key Responses } \\
\hline - Elevated role of mayors & "I don't know about the mayors in other places, but our \\
& mayor went everywhere whenever he knew there was a \\
problem, responding to the requests of local citizens. At & least, he can help coordinate and provide some basic help. \\
& He is concerned about the community's needs and never \\
ignored what we needed."
\end{tabular}

Source: Samples of key responses in this table are selected from quotes from full interviews. 


\section{Elevated Role of Mayors}

Even though the political crisis followed by the coup d'état has suppressed the autonomy of local leaders, it also provides an opportunity for the mayors to demonstrate their leadership qualities. This may have been driven by their desire to be recognized within their own constituency; to be ready when the future election comes. They were afraid that by doing business as usual, they would be relegated to obscurity.

Prior to the coups, national government and legislators asserted strong influence over the municipal mayors in some types of public service. Since Thailand's post-2006 national political crisis, there were frequent changes in the central government and their policies. These changes created uncertainty that impacted local public services. However, the effects of these crises stimulated municipal mayors to be more responsive to local needs and solve local problems.

In addition, local citizens realized the role of local leaders who worked closely with them and knew what their citizens needed. Therefore, the leadership opportunity gained from the national political crisis elevated the roles of mayors in improving local public services. Many participants also mentioned that mayors not only had a responsive style, but also a capacity to coordinate with entities outside their jurisdiction in order to serve basic needs of local citizens. This kind of leadership was not the same in all places but depended on leaders' capacity in serving various needs. Regarding this point, some participants stated that: 
"The mayor has to be actively responsive to all local citizens and respond to what they need. For example, if people do not have a car [for facilitating individual or family activities], the municipality will provide a car for them. Whenever anyone in our community passes away, we help their families to set up the tents and provide utensils-plates and bowls [for the funeral service]. This role of the mayor is a complete change. It depended on local administrators' policies that were designed in pursuit of accommodating local citizens. I think it's likely good. It's not like it was with the central legislators. " (Municipal official, interpersonal communication, August 25, 2016)

"Even though the central government allocated a budget for improving public services, the technical problem still exists. We still have conflicts about service boundaries and jurisdiction. It doesn't involve only the Royal Highway Department because the service boundary connects to other judicial boundaries. It's hard to coordinate. I don't know about the mayors in other places, but our mayor went wherever he knew there was a problem, responding to the requests of local citizens. At least, he can help coordinate and provide some basic assistance. He is concerned about the community's needs and never ignored what we needed. (Local resident, interpersonal communication, August 2016)

\section{Governance}

The literature on governance reports that the new governing process of public organizations values networks and power sharing among multiple actors. In this sense, government is no longer the key player in policy process and public service provision (Enroth, 2011; Peters \& Pierre, 1998; Renn, Klinke, \& Asselt, 2011). Public service delivery process is implemented by multiple actors and networks rather than a single actor and centralized decision makers. Those involved are diverse and work together across boundaries (Peters, 2011). In addition, non-hierarchical and bottom-up administrative style replaces traditional hierarchical pattern that emphasizes command and control administration. This new pattern of governing process values horizontal collective action rather than state-centered administration (Kickert, 1997). 
Importantly, new public governance aims to enhance the quality and effective public service provisions and to accommodate collective goals by stimulating collaboration in decision making among various contributors within government networks and with other societal actors. Moreover, collaboration among multiple sectors opens up opportunities in which different institutional settings can share resources and work together as a strategic partnership in order to provide effective public service (Bevir, 2011; Bingham, 2011). Börzel and Risse (2015) support the findings of this report that political institutional breakdown is not always harmful for governance at local level. It is an opportunity for local governments to work with various groups and sectors collectively and also collaborate across boundaries to achieve a high degree of governance. This helps improve trust with their local communities and safeguard governance from the effects of dysfunctional institutions.

According to participants, Thailand's post-2006 national political crisis created particular opportunities for governance as a moderating variable to local service delivery in four traits: Lessening of central mandates, end of partisan gridlock, increased local responsiveness, and increased intergovernmental collaboration. These themes are summarized in Table 5.4 
Table 5.4 Themes and Samples of Key Responses on Governance

\begin{tabular}{|c|c|}
\hline Themes & Samples of Key Responses \\
\hline $\begin{array}{l}\text { - Lessening of central } \\
\text { mandates }\end{array}$ & $\begin{array}{l}\text { "In the past, the central legislators and even the upper } \\
\text { level-local legislators tried to expand their political } \\
\text { influence. Nowadays, nothing happens. The military } \\
\text { installed legislators and members of the National Council } \\
\text { for Peace and Order apparently do not interrupt us. They } \\
\text { just look at national policy level." }\end{array}$ \\
\hline - $\quad$ End of partisan gridlock & $\begin{array}{l}\text { "Our... municipality is lucky because we don't involve } \\
\text { ourselves much in political protest. As I mentioned, I am } \\
\text { from local level and work for a local community. I don't rely } \\
\text { on national politics." }\end{array}$ \\
\hline $\begin{array}{l}\text { Increased local } \\
\text { responsiveness }\end{array}$ & $\begin{array}{l}\text { "Local people complained directly on social media or } \\
\text { by calling us. Then, we responded and solved that problem } \\
\text { right away. If it happens during the long holiday, we will } \\
\text { arrange and appoint our staff to stand by and respond to } \\
\text { emergency situations such as disease transmission." }\end{array}$ \\
\hline $\begin{array}{ll}\text { - } & \text { Increased } \\
\text { intergovernmental } \\
\text { collaboration }\end{array}$ & $\begin{array}{l}\text { "We have collaborated with and sometimes requested } \\
\text { assistance from them [the district]. In the meantime, when } \\
\text { they wanted us to do something for them, we definitely } \\
\text { facilitated them. On some occasions, we needed some } \\
\text { support from them." }\end{array}$ \\
\hline
\end{tabular}

Source: Samples of key responses in this table are selected from quotes from full interviews.

\section{Lessening of Central Mandates}

While there was less autonomy in local governance, the military government was preoccupied with many other national issues, some of which were to further their own popularity. The effect was that the military government did not have much incentive to be mindful of what they saw as minor local issues. The net result was that local governments felt less of a mandate to serve the military government's agenda. Therefore, local governments had a greater degree of freedom to make their decisions on local affairs and perform their assigned duties with less intervention from central political influences than in the past. Participants expressed their perspectives on this point: 
"In the past, the central legislators and even the upper level-local legislators tried to expand their political influence. Nowadays, nothing happens [with the central government]. The military-installed legislators and members of the National Council for Peace and Order do not bother us. They just look at the national policy level." (Vice mayor, personal communication, August 25, 2016)

"Yes, we have freedom within the municipal council. Anyone here can freely express their thoughts without any intervention from others." (Municipal councilor, personal communication, August 24, 2016)

Some local governments turned these political threats into administrative opportunities. In the midst of political crisis, the prior elected national government and legislators were overwhelmed with political turmoil at the national level. It seemed like they isolated local governments and local communities. When the military-installed government took power, they were more concerned about national political issues than local issues. The national political isolation created an opportunity for local governments and local communities. They could freely operate public services with the lessening of central mandates. Regarding this point, participants described their experiences:

"I think we were lightly detached, but local government has to take action as the front-line operator. The central legislators merely talked to us once or twice a year." (Municipal councilor, personal communication, August 31, 2016)

"Especially in the ... area, the national senators and national representatives rarely looked after their constituents." (Municipal councilor, personal communication, August 24, 2016)

"I feel like they [central legislators] have not coordinated with us much." (Member of municipal council, personal communication, August 25, 2016) 


\section{End of Partisan Gridlock}

Thailand's post-2006 national political crisis induced political gridlock, especially after the 2014 military coup. The NCPO took power away from the elected government and appointed the military government. Its effects brought about a suspension of political institutions such as the constitution, legislators, political parties, and elections. These political institutions have been frozen in pursuit of reducing the political pressures caused by the prolonged political crises. On the positive side, the national political crisis ended partisan gridlock. Its effects mitigated the barriers for local development and decreased political conflicts between Yellow Shirts and Red Shirts. In addition, local administrators seemed to take a more politically neutral and flexible stance.

In order to maintain and improve local service delivery, local government could work with every political sector and with anyone who may have a different political stance. Moreover, it appeared that some local communities benefited from state-led development projects when the military-installed government transferred the grants directly to local communities without moderating actors-e.g., legislators, cabinet members, political parties, and other political interest groups. In the past, these moderating parties could intervene and influence the grant allocation process before those grants were transferred to local communities. Regarding this point, participants shared their experiences:

"For the ... Municipality, national politics doesn't affect us too much. Neither central representatives nor senators influenced us". (Member of municipal council, personal communication, August 30, 2016) 
“... Municipality is lucky because we don't involve ourselves much in political protest. As I mentioned, I am from the local level and work for a local community. I don't rely on national politics." (Mayor, personal communication, August 24, 2016)

\section{Increased Local Responsiveness}

Even though some local governments were undermined by political fears and uncertainties in times of national political crises, these threats positively encouraged local administrators to increase local responsiveness in local service delivery. Officials changed their attitudes about responsiveness to citizens. They respected local residents as guides rather than just service recipients. A change in the mindset of local officials inspired by national political constraints helped enhance local responsiveness in service delivery. Regarding this issue, some participants expressed that:

"When local citizens came to see us in our municipal office, we treated and facilitated them respectfully. We are happy to serve people. We always ask, what can we help you with today? Suffice to say, the municipal officials are here for serving people." (Municipal official, interpersonal communication, August 24, 2016)

"The municipal officials in the ... municipality changed their attitude about the citizens. In the past, they viewed local citizens as service recipients. Nowadays, they view citizens as guides. The municipal officials performed as the implementers, following guidance from the citizens." (Municipal official, interpersonal communication, August 24, 2016)

"It [the effects] contains both positive and negative impacts. The positive impact helped improve the behavior of local administrators." (Mayor, personal communication, August 30, 2016)

Moreover, local leaders and officials were more responsive to solving problems regarding public services occurring in local communities, such as road repair, 
waterworks, electricity, sanitary systems, and other environmental concerns. In fact, some public works - i.e. highways, waterworks, electricity — were not the responsibility of municipalities, but local residents perceived that local government was responsible for these duties. Unavoidably, local leaders had to react to these problems because they affected the lives of their local residents. To find a primary solution, local leaders coordinated with the governmental departments that were responsible for those duties and requested that they solve these problems. On this point, some participants indicated that:

"Local governments expanded very fast in order to respond to the developments. We are with local citizens every day. If people complain about the bad roads in our community, we have to provide budget in order to respond to that problem immediately. In the past, it took more than ten years to get a gravel road, but nowadays it is very fast." (Member of municipal council, personal communication, August 24, 2016)

"If people complain about local problems via the municipal Facebook page, the municipal officials will reply to them and react to the survey and solve that issue immediately." (Municipal official, interpersonal communication, August 30, 2016)

"Local people complained directly on social media or by calling us. Then, we responded and solved that problem right away. If it happens during a long holiday, we will arrange for our staff to stand by and respond to emergency situations such as disease transmission. We just call our appointed staff to respond to the incident immediately." (Municipal official, interpersonal communication, August 30, 2016)

Some participants noted that local governments were responsive to financial shortages whenever the national government's fiscal transfer was delayed. Even though the municipality did not have the autonomy or capacity to undertake the big tasks such as the electric system or waterworks, local leaders and local legislators helped each other to 
figure out an appropriate solution by deciding to use existing funds while waiting for fiscal transfer from the national government. In this political situation, local government determined a fast and effective solution for helping local people. Sometimes, they coordinated with the provincial administration in order to solve their local problems. Regarding this point, participants shared their experiences:

"When the central government delayed the transfer of monthly subsidies for elderly people, we solved this problem by using funds from other existing municipal budgets." (Member of municipal council, personal communication, August 25, 2106)

"For the local government, you can come and see the mayor directly, even though that duty is not the mayor's responsibility. For example, [the people informed] the mayor that the waterworks broke, but the waterworks authority is not the mayor's duty. People thought of us. The Provincial Electricity Authority should be responsible for the electrical outage, but people called us. Eventually, I helped coordinate with those authorities for solving the problem. This is the only thing I can do under my authority. At least they called us, even though some duties are beyond our control." (Mayor, personal communication, August 24, 2016)

\section{Increased Intergovernmental Collaboration}

In the midst of national political crisis, local government suffers from administrative inconvenience and concern about the influence of the military-installed government. Being wary of the hierarchical structure and the strong power of the central government, local governments attempted to insulate themselves by collaborating more closely with other local governments. As an indirect effect of this greater collaboration, the quality of public service at the local level somewhat improved. This fact was borne out several times during the interviews. 
The municipalities collaborated with the provincial administrative authoritiese.g. the chief district officers, the village headmen, and the village health volunteers - in pursuit of sharing power and resources in providing public services. Regarding this point, participants mentioned that:

"They [the municipality] collaborated with the village health volunteers very well because they thought we worked closely with the community. When there was a disease spreading in the community, they normally would inform us and would also report to the hospital. This is the way we built our collaboration. We work closely with local citizens." (Local resident, interpersonal communication, August 24, 2016)

"We have collaborated with and sometimes requested assistance from them [the district]. In the meantime, when they wanted us to do something for them, we definitely facilitated them. On some occasions, we needed some support from them. We normally assisted each other. It looks like the urban community normally helps the rural community. We always supported each other." (Municipal official, interpersonal communication, August 30, 2016)

In addition, some municipalities tried to enhance collaborative governance across jurisdictions and build networks with non-governmental sectors. For example, the mayor of one municipality signed a memorandum of understanding (MOU) with a neighboring municipality in order to mutually manage a joint sanitary and garbage incinerator.

Moreover, the municipalities created a collaborative network through the National Municipal League of Thailand. This organization functions as a union of Thai municipalities. The municipalities use this network to share resources, both tangible and intangible. This collaboration became a vital mechanism to balance and coordinate the power of local governments and the power of the national government. In this regard, the participants noted that: 
"Once the mayor was elected, he requested a neighboring mayor to sign the MOU. We have maintained this collaboration more than 10 years." (Member of municipal council, personal communication, August 31, 2016)

"It is good for reform. Local governments tended to build collaboration. Nowadays, this collaboration became the National Municipal League of Thailand. The chairman of this organization agreed to fight for local governments. Currently, we are working on it." (Mayor, personal communication, August 24, 2016)

\section{Political Economy}

The literature on political economy notes that polity and economy are dissimilar but interdependent. Each variable influences the other via interactive processes (Arndt, 1983; Stern \& Reve, 1980). In policy perspective, political economy refers to policy options that government provides to efficiently benefit everyone in the society (Wamsley $\&$ Zald, 1973). In politically turbulent situations, the decline of political economy is negatively impacted by political crisis. Its effects drive government failure to provide basic services due to lack of resources and fiscal capacity (Menkhaus, 2007; Musekiwa \& Chatiza, 2015).

Although the threats caused by the national political crisis are not only a source for the decline of political economy at the local level, they also can be conditions for opportunities for improving political economy. These effects can have a positive impact on local service delivery. The data analysis shows that the national political crisis created opportunities for political economy in two ways; improved fiscal management and central development support. These findings are also presented and summarized in Table

\section{5 .}


Table 5.5 Themes and Samples of Key Responses on Political Economy

\begin{tabular}{|c|c|}
\hline Themes & Samples of Key Responses \\
\hline - Improved fiscal management & $\begin{array}{l}\text { "The national economy got sick, while our local } \\
\text { government felt a smaller effect. But I will make it [the } \\
\text { economy] stronger by boosting some parts in order to move } \\
\text { our local economies forward." } \\
\text { "...it is convenient and easy for municipal officers to } \\
\text { build a relationship with local people when they went out to } \\
\text { provide tax collection services. They're familiar with the tax } \\
\text { payers." }\end{array}$ \\
\hline - Central development support. & $\begin{array}{l}\text { "The current state-led development policy was designed } \\
\text { and directed by the central government. They allocated the } \\
\text { grant (about 200,000 or 500,000 THB) directly to local } \\
\text { residents." } \\
\text { "It took just two months. It [the state-led development } \\
\text { project] apparently helped stimulate local economies. Local } \\
\text { people have money to spend in the market." }\end{array}$ \\
\hline
\end{tabular}

Source: Samples of key responses in this table are selected from quotes from full interviews.

\section{Improved Fiscal Management}

Although the effects of the political crisis led to political economy crises at both the national and local levels as described in Chapter 4, the political crisis created the conditions for opportunities to political economy. In the midst of political crisis, some municipalities were able to improve fiscal management by boosting their revenues. Based on the interviews, boosting revenues in the municipalities can be described in two characteristic forms. First, by promoting local economic activities; second, by improving the efficiency of revenue collection.

When some municipalities encountered an economic downturn, local people resisted expanding investments and lacked confidence in the economic policies of the national government. At the same time, some municipalities were able to boost local revenues by stimulating local economic activities, with the aim of increasing the income 
of local citizens and urging local entrepreneurship. Local governmental leaders took this opportunity to encourage basic economic activities by inviting investors from outside to open department stores. Municipalities also provided space for expanding the local market. It created another option for small investors in the community to begin new businesses or renovate their existing businesses. In addition, one municipality helped small and medium investors who did not have enough capital to invest in their businesses by coordinating with financial institutions for providing the loans. Regarding this point, the participants suggested that:

"The national economy got sick, while our local government felt a smaller effect. But we will make it stronger by boosting some sectors in order to move our local economies forward. We are a tiny mechanism within the big system; we cannot make it stronger immediately but at least we started to do that. We began doing this in terms of basic infrastructure and encouraging big department stores to open their businesses in our area. In the meantime, we provided spaces as an option for a local market." (Mayor, personal communication, August 24, 2016)

"In [our] municipality, most areas are agricultural. People understood and tried to adjust themselves to current conditions. Our municipality helped them by creating a market space. We also allowed them a few months to farm on the municipal land. For people who don't want to do farming, we provide them spaces for building a local market. There are two locations that we arranged for them. Our aim is to create jobs for people and to boost their revenues from those business activities. We provide them space for investment but they also have to take some responsibilities, too. If they don't have capital, we try to coordinate with the banks and look for a low interest loan. Approval depends on the consideration of each bank and their credit and we cannot guarantee that. We've tried to assist them in this dimension." (Mayor, personal communication, August 24, 2016)

Additionally, some municipalities faced the difficulty in collecting revenues from local citizens due to the consequences of the national economic downturn and political 
uncertainty. Nevertheless, some participants indicated that the increase in local, selfcollected revenues depended not only the economic downturn and political instability, but also the capacity for revenue collection in each municipality. In times of political crisis, municipalities took this opportunity to boost self-collected revenue by improving tax data, tax maps, and tax collection strategies. In addition, municipalities tried to communicate with local citizens and build awareness concerning the outputs and outcomes of tax collection and the consequences of tax compliance. Regarding this point, the participants shared their experiences:

"Tax [collection] depends on the capacity of local governments. Can you collect the tax effectively, such as the Department of Finance? It also depends on the competency of tax collectors. Are you able to get information on the $3.7 \mathrm{sq} . \mathrm{km}$. of [this] municipal jurisdiction? How many rental homes do you have? Do you entirely estimate the property tax? Tax collection depended not only on the central government, but also the tax collectors at the local level. Can you encourage people to pay their taxes? If people don't pay their taxes, what strategy do you employ to enforce the law?" (Member of municipal council, personal communication, August 24, 2016)

"We tried to explain to and communicate with people about the regulations, laws, and consequences of non-compliance. It is the duty of municipal officers to press for payment and follow up. Our municipal jurisdiction is very small, so it is convenient and easy for municipal officers to build a relationship with local people when they went out to provide tax collection services. They're familiar with the taxpayers. They even know the houses of each taxpayer. If local people don't come to the municipality, we will go out and visit them on site. Sometimes, local administrators helped us to communicate with their constituents. The local administrators can help encourage them to pay their tax; they also explain the impact of tax payments. For example, if people do not pay taxes, they won't have good roads. We won't have the budget to repair roads. We won't have beautiful flowers and trees to decorate our local roads." (Municipal official, interpersonal communication, August 25, 2016) 


\section{Central Development Support}

The political economic disruption and slowdown that usually follows the seizure of power by the military warrants the necessity of the national government to allocate more economic stimulus packages for local entities, especially state-led development projects. In times of national political crisis, the role of the national government increases. When the private sector is less active, the government can become more active, rebuilding and using that value. Most development projects and assistance grants at the local level are subsidized directly by the central government.

The pattern of state-led development initiated by the current military government looked different from the development projects undertaken by the previous elected governments. The current military-installed government provided grants directly to local communities instead of local governments. This created an opportunity for development in local communities.

In addition, state-led development projects helped boost economic activities and generated income for local citizens. For some infrastructure projects, local communities hired laborers from the local citizenry to take on projects such as roads, drainage systems, community halls, community waterworks, etc. These projects created jobs within the community, resulting in income for local citizens that they could spend in boosting the local economy. Having a vibrant local economy allows the local people to pay their taxes, thus improving the quality of public service delivery. The business sector can also expand 
their investments. Eventually, local governments utilized those revenues to improve local service delivery. Regarding this point, participants explained that:

"The current state-led development policy was designed and directed by the central government. They allocated the grant (about 200,000 to 500,000 THB) directly to local residents." (Local resident, interpersonal communication, August $25,2016)$

"Currently, our economic status is gradually recovering because the militaryinstalled government has boosted the local economy through the provincial administration. Local people can earn income of about $300 \mathrm{THB}$ per day. It took just two months. It [the state-led development project] helped stimulate local economies. Local people have money to spend in the market." (Local resident, interpersonal communication, August 25, 2016)

"The economic downturn, right? They [the military-installed government] tried to look for a strategy in order to generate money for grassroots people. They believed that after money was received by the local community and circulated within the local market, that 6-7 households would indirectly gain income from the central government. Eventually that money will be circulated and will flow within the markets." (Local resident, interpersonal communication, August 25, 2016)

It is important to emphasize that some local governments still have organizational strategies to recover and boost the local economy, even though those central interventions undermined their local autonomy. Some local governments maintain intergovernmental relationships and adapt themselves to changes in central politics and policies in order to attract state-led development into their local communities. As we will see in the next section, case performance analysis provides an explanation of how high- and lowperformance cases work with the opportunities resulting from the national political crisis. 


\section{Comparison of the High- and Low-Performance Cases in Dealing with the Opportunities Resulting from the National Political Crisis}

Case performance analysis provides an explanation of how the four selected cases are important in this study. This analytical approach is similar to the case performance analysis initially described in Chapter 4 . However, the focal points of the analysis are different. For the high-performance cases, this analysis explores how characteristics of their performance gain advantages from these opportunities. Conversely, investigation of the low-performance cases shows their characteristics and their inability to take advantage of these opportunities. Comparing those characteristics helps answer the question concerning how each of the performance cases studied fared with respect to the others.

In Table 5.6, the key findings are summarized in order to illustrate the characteristics of each group. Then, the analysis provides some explanation on the similarities and differences between high- and low-performance cases through each analytical dimension.

Table 5.6 Case Performance Analysis (Opportunities)

\begin{tabular}{|c|c|c|c|}
\hline $\begin{array}{c}\text { Moderating } \\
\text { Variables }\end{array}$ & $\begin{array}{c}\text { High Performance } \\
\text { (What characteristics of } \\
\text { high-performance cases } \\
\text { gain advantage from this } \\
\text { opportunity?) }\end{array}$ & $\begin{array}{c}\text { Low Performance } \\
\text { (What characteristics of } \\
\text { low-performance cases lead } \\
\text { to the inability to gain from } \\
\text { this opportunity?) }\end{array}$ & Same/Different \\
\hline $\begin{array}{c}\text { Political } \\
\text { Institutions }\end{array}$ & $\begin{array}{l}\text { Same Characteristics } \\
\text { - Improve local } \\
\text { institutional capacity } \\
\text { - Improve institutional } \\
\text { performance } \\
\text { Same Level but Different } \\
\text { Characteristic }\end{array}$ & $\begin{array}{l}\text { Same Characteristics } \\
\text { - Improve local } \\
\text { institutional capacity } \\
\text { - Improve institutional } \\
\text { performance } \\
\text { Same Level but Different } \\
\text { Characteristic }\end{array}$ & Same \\
\hline
\end{tabular}




\begin{tabular}{|c|c|c|c|}
\hline & $\begin{array}{ll}\text { - Increase institutional } \\
\text { inputs from local voice } \\
\text { - Increase institutional } \\
\text { trust }\end{array}$ & $\begin{array}{l}\text { - Improve institutional } \\
\text { facilitation }\end{array}$ & \\
\hline $\begin{array}{c}\text { Civic } \\
\text { Engagement }\end{array}$ & $\begin{array}{ll}\text { Same Characteristics } \\
\text { - } & \text { More reactive to } \\
\text { feedback } \\
\text { - } \\
\text { Boost local } \\
\text { voluntarism } \\
\text { - } \text { Open public spaces for } \\
\text { receiving local } \\
\text { feedback } \\
\text { - } \text { Increase transparent } \\
\text { action } \\
\text { - Enhance local trust } \\
\text { Same Level but Different } \\
\text { Characteristics } \\
\text { - Enhance co-production } \\
\text { between local } \\
\text { government and } \\
\text { citizens }\end{array}$ & $\begin{array}{ll}\text { Same Characteristics } \\
\text { - } & \text { More reactive to } \\
\text { feedback } \\
\text { - } \\
\text { - } \text { Opoost local voluntarism public spaces for } \\
\text { receiving local feedback } \\
\text { - Increase transparent } \\
\text { - } \text { action } \\
\text { Enhance local trust }\end{array}$ & Same \\
\hline $\begin{array}{c}\text { Political } \\
\text { Leadership }\end{array}$ & $\begin{array}{ll}\text { Same Characteristics } \\
\text { - } & \text { Improve } \\
& \text { responsiveness } \\
\text { - } & \text { Enhance coordination } \\
& \text { across boundaries }\end{array}$ & $\begin{array}{l}\text { Same Characteristics } \\
\text { - Improve } \\
\text { Responsiveness } \\
\text { - Enhance coordination } \\
\text { across boundaries }\end{array}$ & Same \\
\hline Governance & $\begin{array}{ll}\text { Same Characteristics } \\
\text { - } & \begin{array}{l}\text { Collaborate across } \\
\text { boundaries }\end{array} \\
\text { - } & \text { Improve local } \\
\text { decision-making } \\
\text { autonomy } \\
\text { - Enhance local-citizen } \\
\text { collaboration }\end{array}$ & $\begin{array}{ll}\text { Same Characteristics } \\
\text { - } & \text { Collaborate across } \\
\text { boundaries } \\
\text { - Improve local decision- } \\
\text { making autonomy } \\
\text { - Improve responsiveness } \\
\text { - Improve problem } \\
\quad \text { solving capacity } \\
\text { Same Level but Different } \\
\text { Characteristics } \\
\text { - Improve local } \\
\quad \text { administrative behavior }\end{array}$ & Same \\
\hline $\begin{array}{l}\text { Political } \\
\text { Economy }\end{array}$ & $\begin{array}{ll}\text { Same Characteristics } \\
\text { - } & \text { Have proactive } \\
\text { economic solutions } \\
\text { - } & \text { Inspire local } \\
\text { entrepreneurship } \\
\text { - } \\
\begin{array}{l}\text { Improve fiscal } \\
\text { performance }\end{array}\end{array}$ & $\begin{array}{l}\frac{\text { Same Characteristics but }}{\text { Different Characteristics }} \\
\text { - Inspire local awareness } \\
\text { on tax collection }\end{array}$ & Same \\
\hline
\end{tabular}


Table 5.6 provides an explanation of characteristics found in both high- and lowperformances cases. The prominent characteristics are identified and summarized through five analytical dimensions. The case performance analysis in this study can be explained as follows:

Political Institutions. Even though the case performance analysis on institutional dimensions in Chapter 4 indicated different characteristics between high- and lowperformance cases in dealing with political threats, it is important to address the issue that both high- and low-performance cases were able to take advantage of opportunities generated by the political crisis. In this analysis, both groups showed the same characteristics.

Since local governments gained a degree of freedom from the central government and the central ministries, local governments took this opportunity to improve local institutional capacity and performance. Citizens perceived that local governments played important roles as the political institutions and public service providers that are closest to them. In addition, this helped local governments to increase institutional trust and relationships with local citizens. This degree of freedom from central authority also made local governments more adaptive to changes in politics and policy. For example, Section 44 often helped turn administrative constraints into administrative opportunities. Local governments took advantage of the military laws to solve complicated issues within local administration such as the patronage system and corruption within local personnel 
management, suspension and removal of corrupted mayors, local councilors, and local officers.

Furthermore, the analysis of the high-performance cases showed that the political crisis increased institutional inputs from local voices through national government offices called Damrongdharma Centers. These became positive inputs for policy-making processes and the improvement of public service provisions. The characteristics as explained above indicated that the low-performance cases were capable of taking advantage of an opportunity as much as were high-performance cases.

Civic Engagement. Based on case performance analysis, high-performance and low-performance cases within the civic engagement dimension exhibited the same characteristics. Low-performance cases were able to take advantage of this opportunity as much as high-performance cases. Although the characteristics of civic engagement within local governments as discussed in Chapter 4 seemed to be beyond local government's capacity to address political threats, the non-formal engagement and non-political activities helped local governments from both groups to be more responsive to citizen feedback. In addition, both groups were able to take advantage of these opportunities on the same level.

For the high-performance cases, political threats impeded civic engagement in local communities, especially political civic engagement. At the same time, these same threats triggered opportunities for local governments to boost local voluntarism through non-formal and non-political engagements, such as social, traditional, sporting, and 
religious activities. Consequently, these activities became a starting point to enhance coproduction between local government and citizens. Local governments utilized these opportunities to open public spaces for local people to provide feedback and even work together. Moreover, when local people became more closely engaged with local governments, transparency and trust increased within local administrations.

The low-performance cases used this advantage to open public spaces for enabling citizens to voice their concerns, as did the high-performance cases noted above. Local residents felt more comfortable engaging with their municipal governments. In addition, local governments tended to value citizen voices as a legitimate source of input for improving services and local policies, while local people were eager to provide feedback to local governments.

Political Leadership. Case performance analysis indicated that both high- and low-performance cases were similar in their ability to take advantage of the opportunities created by political crisis. It should be noted that the low-performance cases had as much capacity to take advantage of these opportunities as the high-performance cases. Both high- and low-performance cases appeared to be actively responsive to problems and concerns within the local community. When local governments did not have enough capacity to cope with certain problems, they used this opportunity to identify their true capacity to coordinate with other public organizations that were beyond their autonomous boundary. This coordination was a vital mechanism to help local governments resolve their problems. 
Additionally, the uncertain political situation stimulated both groups to increase their capacity for dealing with emerging issues that arise in times of political crisis such as natural disasters, diseases, fire, and economic downturns. Moreover, it provided an opportunity for both groups to maintain their horizontal networks with all levels of local governments.

Governance. All cases shared this characteristic. They were able to take advantage of the opportunities created from the political crisis to collaborate with multiple sectors across jurisdictional boundaries. They also exchanged resources with the upper levels of central government agencies. For example, the low-performance cases provided assistance grants to local governments to support a sports activity organized by the district-i.e. a provincial administrative agency. In addition, the low-performance cases shared the same level of performance but with different characteristics. For lowperformance cases, local government administrators used this opportunity to improve the behavior of local administrators. Local administrators and local officials should not be influenced by specific political advocacy or interest groups. Due to the new legal constraints, local governments are more cautious regarding local administration and decision-making.

Political Economy. Case performance analysis indicated that both high- and lowperformance cases were capable of taking advantage of the opportunities created by the political crisis. Specifically, the economic downturn created an opportunity to inspire local government leaders to be more proactive with regard to economic solutions. For the 
high-performance cases, local governments tried to help local people to improve business activities in order to boost local revenue. Local governments encouraged external business sectors to expand and invest in their local areas, such as bringing in department stores.

In addition, local governments utilized this opportunity to improve fiscal performance by boosting self-collected revenues. The most efficient way that highperformance cases employed was to improve the tax database and tax collection strategies. Local councilors and local officers helped each other communicate with local people and motivate them to pay their taxes. The low-performance cases were similar to the high-performance cases but with different characteristics. Specifically, the low performance cases took this opportunity to improve revenue collection by enhancing their local residents' awareness of tax collection.

\section{Summary}

In conclusion, this chapter described the effects of Thailand's post-2006 national political crisis and the resulting opportunities for local government service delivery. The key findings gained from the participants across four municipalities were presented through five moderating variables, as shown in "Graphical Representation of Findings: How National Political Crisis Creates Opportunities to Local Government Service Delivery" (see Appendix B).

First, political institutional failure created particular opportunities for local government service delivery. To solve legal limitations and find the way out of political 
gridlock, the military-installed government used Section 44 of the 2014 Interim Constitution to lessen some complicated administrative procedures. They also provided a fast-track channel through the office called Damrongdharma Centers in order to receive citizens' complaints regarding public services directly from local citizens. In addition, political crisis encouraged local institutional capacity. Local governments used institutional connections to share resources and build collaboration for improving public services.

Next, the national political crisis created opportunities for improving civic engagement at local level. Local residents felt comfortable with helping and working together with their local governments. This helped increase trust between local governments and their constituents. Due to local trust, residents were eager to participate in the council and town hall meetings and shared their thoughts regarding public service improvement and other local development issues. Meanwhile, local residents were comfortable in sharing their thoughts with local leaders and also working together with local governments in pursuit of increasing community building.

Third, as a way to appease their own constituency, many local mayors acted more swiftly, thus emphasizing their leadership. Fourth, the national political crisis resulted in a decline of central mandates. Its effects mitigated the political tensions or even ended partisan gridlock in local communities. Moreover, the political crisis stimulated local responsiveness and intergovernmental collaboration in order to serve the needs of local residents and maintain quality of public services. Finally, from the political economy 
point of view, the economic disruption that usually follows a seizure of power by the military warrants the necessity of the national government to allocate more economic stimulus packages to local entities. It was an opportunity for local governments to improve fiscal management. Importantly, the effects of national political crisis mediated by political economy directly affected local government service delivery performance. 


\section{Chapter 6 \\ Conclusion and Discussion}

\section{Summary of Findings}

Thailand's local government service delivery has had to confront challenges because of national political crises, especially a prolonged crisis that began in 2006 . The effects of these crises led to institutional breakdown and economic decline (Human Rights Watch, 2016; Sussangkarn \& Nikomborirak, 2016; United Nations, 2016). Conventional scholarship generally accepts that political crisis will, as a rule, create considerably more harm than good for local service delivery. Importantly, most literature on the effects of political crises found that political crises create negative impacts for local autonomy, civic capacity and engagement, local economy, and quality of local public service provision (Bland, 2011; Menkhaus, 2007; Muchadenyika, 2017; Musekiwa \& Chantiza, 2015). Very few have shown positive effects, notably Börzel and Risse (2015). These previous studies did not highlight the important moderating variables (political institutions, civic engagement, political leadership, governance, and political economy) that are influential to local service delivery (Batonon, 2015; Curristine, Lonti, \& Joumard, 2007; UNDP, 2016).

To answer whether Thailand's post-2006 national political crisis affected local government service delivery, the data analyzed in this study were derived from primary sources that included semi-structured in-depth interviews and focus-group discussions. Four municipalities located in Khon Kaen province were logically selected as the 
research sites. The interviews were conducted with key informants (mayors, chairpersons of municipal councils, and municipal councilors) and focus group participants (heads of municipal departments, community leaders, and local residents). The interview data were transcribed and thematically analyzed, and some appropriate comments were selected and translated from Thai to English. These direct quotes were brought into the relevant theme.

Political crises have generally been seen or assumed as having negative impacts on local service delivery, but this study shows that this depends on how it filters down to the local level through the five moderating variables. According to the analysis of data in this study, Thailand's post-2006 national political turmoil created both threats and opportunities for local service delivery performance through these five moderating variables. The threats resulted in political institutional breakdown of local governments weakened electoral mechanisms and caused the suspension of local authority. Political fears and uncertainties reduced civic participation and weakened policy networks in local communities. In addition, political crises reduced autonomy and increased civil conflict and risks for local leaders. In addition, trust and communication between central and local governments were decreased, resulting in a reversal of decentralization and declining accountability. Also, hierarchical interactions in internal governance settings were increased. Moreover, political turmoil induced negative impacts for political economy. This caused local economic output declines, revenue declines within local business sectors, and personal and household financial weakening. 
Conversely, political institutional breakdown enabled particular opportunities for local service delivery. To solve legal limitations and find ways out of political gridlock, the military-installed government used Section 44 of the 2014 Interim Constitution to lessen some complicated administrative procedures. The government also provided a fast-track channel called Damrongdharma Centers in order to receive citizens' complaints regarding public services. Furthermore, the political crisis encouraged local institutional capacity, with local governments using institutional connections to share resources and build collaborations for improving public services. Local residents felt comfortable in engaging with their local governments, which helped to increase trust between local governments and their residents. This resulted in increased trust, residents were eager to participate in council and town hall meetings, and they were comfortable sharing their thoughts regarding public service improvement. This helped increase community building.

Moreover, as a way to appease their own constituency, many local mayors acted more swiftly, thus accentuating their leadership abilities. These factors mitigated central mandates and political tensions and even ended partisan gridlock in local communities. Political crisis helped stimulate local responsiveness and intergovernmental collaboration in order to maintain the quality of public services. Crucially, it was an opportunity for local governments to improve fiscal management and boost local economic activities that helped enhance local fiscal capacity to provide effective service. 


\section{Discussion and Conclusion}

According to the findings of the study, the threats caused by the national political crisis in Thailand since 2006 are in accordance with conventional wisdom and in line with the literature addressed in this study. Crisis is generally seen as causing a negative effect on local government, while the opportunities gained from political crises have been under-recognized. Hence, this study sought to examine the opportunities embedded within national political crises.

The findings challenge the notion of Kurlantzick (2011), who argues that political crisis caused government breakdown and undermined the development of democratic activities. Even though Thailand's national political crisis did undermine democratic progress, there are some means by which local residents were able to provide feedback as information to the central government. For example, the Damrongdharma Centers provided an outlet for local people to send their complaints concerning local public services and social problems through to the central government and there were positive impacts on local institutional capacity through local partnerships. Moreover, this study found that the continuing political crisis following the 2014 military coup reduced the complicated approval processes due to the impacts of Section 44 of the 2014 interim Constitution.

In addition, an issue of local institutional capacity found in this study is different from a case in Zimbabwe studied by Musekiwa and Chatiza (2015). Their study found 
that in the midst of political crisis, local residents tried to establish citizen-led organizations in order to help local governments provide some types of public service when local authorities were incapable or had insufficient management capacity to address the requirements of local residents. In the case of Thailand, although political crisis triggered negative impacts to local government, local institutional capacity, especially resource sharing among local governments, remained functional.

There were also some opportunities for civic engagement concealed within the political crises. Local government and citizens increasingly worked together in local affairs, especially in non-political activity. Residents trusted their local governments in terms of responsiveness and local service delivery more than national government. They were eager to be involved in formal policy decision-making processes organized by local governments. Local residents were not hesitant to express their views regarding public concerns and they attended public meetings and volunteering activities by overlooking differences in political belief, i.e. Red Shirts and Yellow Shirts.

The findings in this study also differ from a study by Musekita and Chatiza (2015). Their study found that a political crisis created political unification between central and local government simply because, in the study they conducted, both the central and local governments were from the same party. While that seemed to be positive, it led to local governments not bothering with encouraging public participation in local activities. 
Furthermore, the role of some mayors has been elevated after political institutional breakdown, while the role of national legislators and their influence on local leaders declined. Residents increasingly recognized the capacity of mayors who stayed close to them and successfully responded their needs. The mayors were more proactive to local concerns and problem solving. This finding supports the opinions of Fiedler (1996) and Wart (2003) that effective public leaders should have personal skills and capacity to serve the needs of citizens and to make decisions on service provision. Similarly, Boin and "t Hart (2003) demonstrated that leaders are elevated to be "heroes" once they successfully used their capacity and skills to cope with and diminish people's concerns.

Thailand's political unrest allowed local governments to gain some degree of freedom from central mandates on local affairs because central government was overwhelmed with political conflict at the national level. These impacts reduced political pressures on local government and eased local civil conflicts. This helped local governments to provide local services more easily than in the past, while intergovernmental collaboration was improved. The current findings also contrast with a study conducted by Muchadenyika (2015). He found that prolonged political crisis in Zimbabwe induced central government interference in local affairs by bringing back some local services to central authority. However, the current findings do support the argument addressed by Börzel and Risse (2016), who argue that dysfunctional political institutions are not always bad thing for governance. The institutional breakdown 
maintains the degree of governance at local level because local governments build trust within local communities by coordinating with other partnerships across boundaries.

Finally, the effects of national political crises improved political economy. Some local governments were able to boost local revenues by encouraging economic activities and by enhancing the efficiency of revenue collection. State-led development projects were initially perceived as threats to local governments in terms of interference and recentralization, but they can be a vital source for enhancing local economy and improving local service delivery.

There is also a conflict between the findings of this study and those of Menkhaus (2007) and Musekiwa and Chatiza (2015), who argue that government collapse due to political instability led to insufficient resources and fiscal restraints at local levels. In addition, Sussangkarn and Nikomborirak (2016) asserted that Thailand's political crisis created negative impacts on the Thai economy as a whole and also triggered uncertainty for foreign investment. Their findings are similar to what this study found under the dimension of threats. Nevertheless, their work did not mention any opportunities concealed within political crisis.

In conclusion, this study found that through the five moderating variables, national political crisis in Thailand has had both positive and negative impacts on local government service delivery. The findings in this study deviate from the conventional wisdom that associates crisis only with threats while ignoring new opportunities. 
Another interesting point discovered in this study is that threats and opportunities coexist side-by-side in both the cases of high-performing and low-performing local governments. This makes it more encouraging that, while political crisis usually is a cause for concern, there is also potential for rectification of existing problems. It is important, therefore, to highlight that one of the explanations for the existence of both threats and opportunities can be provided through the logic of action and reaction concept. Initially, national political turmoil would create threats that influence local service delivery as negative forces. These effects induce local governments to respond, as a reaction, to this crisis in order to maintain quality or effectiveness of public service delivery. This reaction is seen as a positive force or opportunity for maintaining or improving local service delivery.

With these findings, it is important to mention that with the qualitative research design, we cannot evaluate the statistical interaction among the five moderating variables. The uniformity of both threats and opportunities may be an artifact of the interaction of the five moderating variables. There was evidence, as mentioned before, that the suspension of political institutions affects political participation and civic engagement which is also related to autonomy of the leaders, collaboration, and ultimately political economy. At the outset, the author was able to observe the consequences of political institutions on other moderating variables. This is analogous to the existence of the problem of multicollinearity among the explanatory variables in quantitative research. With this potential methodological query posing a challenge, the interpretation of the results in this study should be done with caution, and the results should be taken as a 
preliminary. In part, it is because the data used in this research were collected from individuals, which may entail subjective opinion, rather than objective performance indicators of local governments

\section{Implications}

It is of particular interest to ask whether the opportunities embedded in the political crises mentioned in Chapter 5 are specific to the current situation or can be maintained over time. Only time and future research can provide an answer. The longterm implication is that if Thai local governments are not granted greater management autonomy when the country returns to more democratic principles and when there is no single person with the absolute power endowed by Section 44 to guide or shield the local government, the central bureaucratic power may relentlessly exert a strong influence on local governments again. With that scenario, Thailand is again threatened by the prospect of highly centralized management.

As Fry (2014) noted, crises often conceal particular opportunities, especially for political institutional rearrangement. In the optimistic implications of this study, a crisis may provide opportunities for institutional transformation towards decentralized governance. This could happen if local governments can unite in their interests under the bargaining power of the National Municipal League of Thailand. The League can help diverse local governments in developing and uniting them in promoting decentralization. In addition, when general elections are again permitted, local governments could even 
propose and negotiate a policy mandate to all parties that commits to adopt decentralization as a high-priority policy agenda. This strategy may attract more interest among local voters. If the crisis does lead to this improvement, then over the long term the benefits will certainly outweigh the price paid. In any event, whether it is a centralized or decentralized system, local governments cannot function without strong policy support from the central government.

The results of this study also provide a basis for advancing or revising the concept of new public service under the stress of political crisis. As described earlier, crisis theory generally explains that crises normally have negative effects on local government service delivery. We found that some sorts of crises, such as political crises, are useful as opportunities for institutional rearrangement, improving the role of public leadership, opening a window of opportunity for policy or organizational change, and improving strategy for management of future crises.

\section{Policy Recommendations}

It is notable that while we see windows of opportunity for social transformation, we do not see any clear initiative by the NCPO to usher the country toward decentralized management. Based on the political history of Thailand and its experience with 19 coups, all had the hidden agenda of protecting the interests of the bureaucracy and the ruling elites. Although all coups cited the public interest as a justification for staging the coup, no coup endowed more self-governing power to people. In all likelihood, the next general 
election will be the beginning of a new political crisis. The sustainable solution to avoiding political crises in Thailand lies in granting more management autonomy to local government through fiscal decentralization, administrative decentralization, and political decentralization. At present, the powers in Thailand do not seem be interested in any of these.

\section{Limitations}

This study encompasses two major uncertainties, a data validity problem and a reliability problem. The data validity problem arises in that some questions may be raised whether the municipalities are representative of Khon Kaen province, and whether the interviewees were honest in their answers or personal experiences or did political perception discourage them in giving direct answers. In addition, this study used specific cases for data collection and purposively recruited the interview participants by setting the criteria that were influenced and set by the researcher. The opinions they provided during the interviews were based on their personal experiences and perceptions. Both the research sites and interview participants were considered as non-representative. This could lead to influence by the researcher and biased data.

Regarding reliability, the confidence of any researcher in the social science field is somewhat limited by the concern over whether data is reliable over time or if it is unique to a very narrow period, in this case 2016. While the pattern of this particular political crisis seems to be the same and will continue to be in this form, the nature and 
patterns of the political situation in Thailand 10 years from now might have changed. When the situation changes, it affects people's perceptions. If this study had been conducted in 2010 or in 2012 , we may have produced a very different result. The concern here is that the reliability of data collected in this study may be affected by effects associated with the time and place when this research was conducted. It is important, therefore, to note that time and the environment of the interviews may have influenced the reliability. In the context of this study, the ongoing national political crisis may have created apprehension among the participants about military investigation because the research topic under study is related to politics and government performance. As a result, the participants might have felt reluctant to be completely honest or open in discussing issues related to the current political crisis in Thailand.

\section{Future Research}

As the results from this study are preliminary, future research is recommended. The scope of the future research could be broadened to test the sustainability of opportunity as well as to ensure a representative study population. An additional area of research would be to focus on a better understanding of the impact of political crisis on the cultural and behavioral aspects of society at large. Moreover, this research could be conducted as a comparative case study using different regions in Thailand.

As a follow-up to this work, there are several tasks that should be carried out. For example, based on inductive approach the author will develop an article to submit to a 
peer-reviewed journal. The paper will present an analytical framework to test the impact of political crisis on local government service delivery. In short, the author is arguing against the common belief that political crisis always undermines or disrupts the service delivery system. The general framework will argue that when we want to assess the impact of political crisis we need to look at both the negative and positive sides- threats and opportunities. The working title of this article is, "Political Crisis and Local Service Delivery: A Framework for Analysis.”

Additionally, the author proposes that, when the political situation returns to normal, or at least after the next general election, research should be conducted to evaluate the sustainability of the opportunities revealed in this study. Moreover, this research should be carried out using a more representative sample of the population of Khon Kaen Province, or even drawing on a representative sample of other provinces in northeastern Thailand. In addition, this future study should investigate the scoped conditions before 2006 to see how political crisis created negative or positive events in that period of time. This research should add more understanding about the history of political crisis and its course for the future. This study should provide a better understanding of the impact of national political crisis on cultural and behavioral aspects in Thai society.

Finally, the author is looking for an opportunity to conduct a comparative case study, comparing Thailand with other countries that have prolonged national political 
crisis and military interventions such as Turkey or some countries in Africa, using the framework developed in this study. 


\section{References}

Adler, R. P. \& Goggin, J. (2005). What do we mean by “civic engagement"? Journal of Transformative Education, 3(3), 236-253. Retrieved from http://doi:10.1177/1541344605276792

Agranoff, R., \& Radin, B. A. (2014). Deil Wright's Overlapping Model of Intergovernmental Relations: The Basis for Contemporary Intergovernmental Relationships. Publius: The Journal of Federalism, pju036. Retrieved from http://publius.oxfordjournals.org/

Ansell, C., \& Gash, A. (2008). Collaborative Governance in Theory and Practice. Journal of Public Administration Research \& Theory, 18(4), 543-571. Retrieved from doi:10.1093/jopart/mum032

Arndt, J. (1983). The Political Economy Paradigm: Foundation for Theory Building in Marketing. Journal of Marketing, 47(4), 44-54. Retrieved from http://doi:10.2307/1251398

Associated Press. (May 23, 2014). Thailand coup: Gen. Prayuth Chan-ocha, who led military takeover, a strong defender of monarchy. Fox News, World. Retrieved from http://www.foxnews.com/world/2014/05/24/thailand-coup-genprayuth-chan-ocha-who-led-military-takeover-strong-defender.html

Avis, W. R. (2016). Urban governance (Topic Guide). Birmingham, UK: GSDRC, University of Birmingham. Retrieved from http://www.gsdrc.org/wpcontent/uploads/2016/11/UrbanGov_GSDRC.pdf

Baker, C. and Phongoaichit, P. (2014). A History of Thailand. Cambridge: Cambridge University Press.

Baker, C. (2016). The 2014 Thai Coup and Some Roots of Authoritarianism. Journal of Contemporary Asia, 46(3), 388-404. Retrieved from http://www.tandfonline.com/doi/pdf/10.1080/00472336.2016.1150500?needAcce ss $=$ true

Balassiano, K. (2011). Civic Space Production and Local Government Capacity: Lessons from Muang Klang, Thailand. Journal of Social Issues in Southeast Asia, 26(1), 58-79. Retrieved from http://muse.jhu.edu/article/429097.

Bao, G., Wang, X., Larsen, G. L., \& Morgan, D. F. (2013). Beyond new public governance: a value-based global framework for performance management, governance, and leadership. Administration \& Society, 45(4), 443-467. Retrieved from http://doi:10.1177/0095399712464952

Batonon, I. (2015). Social accountability: An introduction to civic engagement for improving service delivery. New York, NY: International Rescue Committee.

Retrieved from https://www.rescue.org/sites/default/files/document/565/ircsocialaccountabilitydis cussionpaper.pdf

BBC. (July 13, 2012). Profile: Thailand's reds and yellows. BBC News, Asia-Pacific. 
Retrieved from http://www.bbc.com/news/world-asia-pacific-13294268.

Besley, T., \& Burgess, R. (2002). The Political Economy of Government

Responsiveness: Theory and Evidence from India. The Quarterly Journal of

Economics., 117(4), 1415-1451. Retrieved from

https://doi.org/10.1162/003355302320935061

Bevir, M. (2006). Democratic Governance: Systems and Radical Perspectives. Public Administration Review, 66(3), 426-436. Retrieved from http://doi:10.1111/j.15406210.2006.00599.x

. (2011). Governance as theory, practice, and dilemma. In Mark Bevir (Ed.), the SAGE Handbook of Governance (pp. 1-35). Thousand Oaks, CA: SAGE Publications Inc.

Bingham, L. B. (2011). In Mark Bevir (Ed.), The Sage Handbook of Governance (pp. 386-401). Thousand Oaks, CA: SAGE Publications Inc.

Bland, G. (2011). Overcoming a decade of crisis: Zimbabwe's local authorities in transition. Public administration and development, 31(5), 340-350. Retrieved from http://onlinelibrary.wiley.com/doi/10.1002/pad.620/pdf

Blondel, J., \& Thiébault, J. L. (Eds.). (2009). Political leadership, parties and citizens: the personalization of leadership. New Yok: NY. Routledge.

Boex, J, Malik, A. A., Brookins, D., \& Edwards, B. (2016). Dynamic cities? The role of urban local governments in improving urban service delivery performance in Africa and Asia. Washington, DC: Center on International Development and Governance at the Urban Institute.

Boin, A, 't Hart, P. (2003). Public Leadership in Times of Crisis: Mission Impossible? Public Administration Review, 63(5), 544-553. Retrieved from http://www.jstor.org.proxy.lib.pdx.edu/stable/3110097

Boin, A.,'t Hart, P., Stern, E., \& Sundelius, B. (2005). The Politics of Crisis Management: Public Leadership under Pressure. New York, NY: Cambridge University Press.

Boin, A., 't Hart, P., Stern, E. \& Sundelius, B. (2017). The Politics of Crisis Management: Public Leadership under Pressure. New York, NY: Cambridge University Press.

Börzel, T., \& Risse, T. (2016). Dysfunctional state institutions, trust, and governance in areas of limited statehood. Regulation \& Governance, 10(2), 149-160.

Retrieved from http://doi:10.1111/rego.12100

Bowornsak Uwanno. (2011). พลวัติของการเมืองไทย [Dynamics of Thai politics]. Institute of culture and arts journal, 2(24), 19-25. [In Thai] Retrieved from http://ejournals.swu.ac.th/index.php/jica/article/viewFile/1864/1914.

Bowornwathana, B. (2000). Governance Reform in Thailand: Questionable Assumptions, Uncertain Outcomes. Governance, 13(3), 393-408. Retrieved from http://stats.lib.pdx.edu/proxy.php?url=http://search.ebscohost.com.proxy.lib.pdx.e $\mathrm{du} / \operatorname{login}$. aspx $?$ direct $=$ true $\& \mathrm{db}=\mathrm{aph} \& \mathrm{AN}=3420189 \&$ site $=$ ehost-live 
Braun, V., \& Clarke, V. (2006). Using thematic analysis in psychology. Qualitative research in psychology, 3(2), 77-101.Retrieved from http://www-tandfonlinecom.proxy.lib.pdx.edu/doi/pdf/10.1191/1478088706qp063oa

Bremmer, I. (August 11, 2016). Here's what you need to know about Thailand's new Constitution. Time-World. Retrieved from http://time.com/4448655/thailandconstitutional-referendum/

Brown, P. (May 30, 2014). Thailand's $19^{\text {th }}$ coup, Asia's most vibrant democracy. CBC News/World. Retrieved from http://www.cbc.ca/news/world/thailand-s-19thcoup-asia-s-most-vibrant-democracy-patrick-brown-1.2659180

Bryson, J. M., Crosby, B. C. and Stone, M. M. (2006), The Design and Implementation of Cross-Sector Collaborations: Propositions from the Literature. Public Administration Review, 66 (1), 44-55. Retrieved from doi:10.1111/j.15406210.2006.00665.x

Buchanan, J. M. (1964). WHAT SHOULD ECONOMISTS DO? Southern Economic Journal (Pre-1986), 30(3), 213-222. Retrieved from https://search.proquest.com/docview/217149651 ?accountid=27797

Buckwalter, N. D. (2014). The Potential for Public Empowerment through Government-Organized Participation. Public Administration Review, 74(5), 573584. Retrieved from http://onlinelibrary.wiley.com.proxy.lib.pdx.edu/doi/10.1111/puar.12217/epdf.

Thawilwadee Bureekul (2009). พลวัติการมีส่วนร่วมของประชาชน: จากอดีต จนถึงรัฐธรรมนูญแห่ง ราชอาณาจักรไทย พุทธศักราช 2550 [Dynamic of citizen participation: From the past to the 2007 Thailand's Constitution]. Bangkok, Thailand. A. P. Graphic Design and Printing Ltd. Retrieved from http://kpi-offscan.kpi.ac.th/multim/kpiebook/b13521.pdf

Bureekul, T., \& Thananithichot, S. (2012). Trust and Social Cohesion, the Key to Reconcile Thailand's Future. International Journal of Social Quality, 2(2), 81-97. Retrieved doi:10.3167/IJSQ.2012.020206

Carboni, J. L., \& Milward, H. B. (2012). Governance, privatization, and systemic risk in the disarticulated state. Public Administration Review, 72(s1), S36-S44.

Retrieved from http://onlinelibrary.wiley.com.proxy.lib.pdx.edu/doi/10.1111/j.15406210.2012.02670.x/epdf.

Chachavalpongpun, P. (2014). The politics of international sanctions: The 2014 coup in Thailand. Journal of International Affairs, 68(1), 169-XI.

Retrieved from http://stats.lib.pdx.edu/proxy.php?url=http://search.proquest.com.proxy.lib.pdx.ed $\mathrm{u} /$ docview/1644459188? accountid=13265

Chambers, P. (2015). Civil-military relations in Thailand since the 2014 coup. Peace 
Research Institute Frankfurt. Retrieved from

https://www.hsfk.de/fileadmin/HSFK/hsfk_publikationen/prif138.pdf

Channa, A., \& Faguet, J. (2016). Decentralization of Health and Education in

Developing Countries: A Quality-Adjusted Review of the Empirical Literature

1. The World Bank Research Observer, 31(2), 199-241. Retrieved from https://doi.org/10.1093/wbro/lkw001

Charoensiri, C., Getsuwan, R. \& Girdwichai, N. (2016). ความเป็นอิสระของท้องถิ่น ภาวะผู้นำ

ท้องถิ่น และการจัดการปกครองท้องถิ่นที่เน้นประชาชน : กรณีศึกษาการปกครองท้องถิ่นในจังหวัดมหาสารคาม

[Local Autonomy, Leadership of Local Leaders, and Citizen-Centered Local Governance: A Case Study of Local Administration in Mahasarakham Province]. Chophayom Journal, 27(2), 73-81. [In Thai]. Retrieved from https://www.tcithaijo.org/index.php/ejChophayom/article/view/73493

Cities, U. (2009). The impact of the global crisis on local governments. Barcelona: United Cities and Local Governments. Retrieved from http://www.citieslocalgovernments.org/upload/doc publications/9225580315_(EN)_uclgcrisis(eng).pdf .

Connick, S., \& Innes, J. E. (2003). Outcomes of collaborative water policy making: Applying complexity thinking to evaluation. Journal of environmental planning and management, 46(2), 177-197. Retrieved from http://dx.doi.org/10.1080/0964056032000070987

Thai Const. (1997). รัฐธรรมนูญแห่งราชอาณาจักรไทย พ.ศ. ๒๕๕๕๐ [The Constitution of Kingdom of Thailand]. Retrieved from http://www.refworld.org/docid/3ae6b5b2b.html

Crispin, S. W. (February 10, 2016). The staying power of Thailand's military. The Diplomate. Retrieved from http://thediplomat.com/2016/02/the-staying-power-of-thailands-military/

Curristine, T., Lonti, Z. \& Joumard, I. (2007). Improving public sector efficiency: Challenges and opportunities. OECD Journal on Budgeting, 7(1), 1-41. Retrieved from https://www.oecd.org/gov/budgeting/43412680.pdf

Decentralization Plan and Process Act of Thailand. (1999). พระราชบัญญัติแผนและขั้นตอนการ กระจายอำนาจให้แก่องค์กรปกครองส่วนท้องถิ่น พ.ศ.๒ ๕์ ๕์ [Decentralization Plan and Process Act of Thailand]. Retrieved from http://www.local.moi.go.th/2009/pdf/aumnat2542.pdf

Denhardt, R. B. \& Denhardt, J. V. (2000), The New Public Service: Serving Rather than Steering. Public Administration Review, 60 (549-559). Retrieved from doi: 10.1111/0033-3352.00117

Denhardt, J.V. \& Denhardt, R.B. (2003). The new public service, serving, not steering. Armonk, NY: M.E. Sharpe. Inc. (2011). Leadership. In Mark Bevir (Ed.), the Sage Handbook of Governance (pp. 419-435). Thousand Oaks, CA: Sage Publication. Dobler, C. (2011). Impact of Formal and Informal Institutions on Economic Growth. 
Frankfurt am Main: Peter Lang GmbH, Internationaler Verlag der

Wissenschaften. Retrieved from

http://ebookcentral.proquest.com.proxy.lib.pdx.edu/lib/psu/detail.action?docID=1 054760

Dalpino, C. (2012). Thailand in 2011: High Tides and Political Tensions. Asian

Survey, 52(1), 195-201. Retrieved from doi:10.1525/as.2012.52.1.195

Emerson, K., Nabatchi, T., \& Balogh, S. (2012). An Integrative Framework for Collaborative Governance. Journal of Public Administration Research \& Theory, 22(1), 1-29. Retrieved from https://doi.org/10.1093/jopart/mur011

Fiedler, F. E. (1971). Validation and extension of the contingency model of leadership effectiveness: A review of empirical findings. Psychological Bulletin, 76(2), 128148. Retrieved from http://dx.doi.org.proxy.lib.pdx.edu/10.1037/h0031454 . (1996). Research on Leadership Selection and Training: One View of the Future. Administrative Science Quarterly, 41(2), 241-250. Retrieved from doi:10.2307/2393716

Fisher, J. (May 22, 2014). Thailand military sizes power in coup. BBC News. Retrieved from http://www.bbc.com/news/world-asia-27517591

Forum-Asia. (April 3, 2015). Thailand: Invocation of Article 44 of Interim Constitution Will Continue to Deteriorate Rights Situation in the Country. Retrieved from https://www.forum-asia.org/uploads/wp/2015/04/FA-PressRelease-Thailand-Article-44.pdf

Frederickson, H. G. (1996). Comparing the reinventing government movement with the new public administration. Public Administration Review, 56(3), 263-270. Retrieved from https://search.proquest.com/docview/197170139? accountid=27797

Frederickson, H.G., Smith, K.B, Larimer, C.W., \& Licari, M. (2012). The public administration theory primer. Philadelphia, PA: Westview Press

French, E. (May 18, 2016). Three imminent crises that could shape political risk in Thailand. Global Risk Insights. Retrieved from http://thediplomat.com/2016/02/the-staying-power-of-thailands-military/

Fry, G. W. (2014). A comedy of errors a critical analysis of the political drama in Thailand. Harvard International Review, 35(4), 29-31. Retrieved from http://hir.harvard.edu.proxy.lib.pdx.edu/

Fuller, T. (August 20, 2014). Junta leaders is named new Prime Minister. The New York Times, Asia Pacific. Retrieved from https://www.nytimes.com/2014/08/21/world/asia/top-general-becomes-thaiprime-minister-sealing-militarys-rule.html?_r=0

Gray, A., Jenkins, B. \& Leeuw, F. (2003). Collaborative government and evaluation: The implication of a new policy instrument. In Andrew Gray, Bill Jenkins, Frans Leeuw, and John Mayne (Ed.), The Challenge for Evaluation, 
Collaborative in Public Services (pp. 1-28). New Brunswick, NJ: Transaction Publishers.

Greer, S. (2010). Territorial politics in hard times: the welfare state under pressure in Germany, Spain, and the United Kingdom. Environment and planning. $C$, Government \& policy, 28(3), 405. Retrieved from http://core.ac.uk/download/pdf/6307117.pdf

Hall, P. A. \& Taylor, R. C. R. (1996). Political science and the three new institutionalisms. Political Studies, 44(5), 936-957. Retrieve from http://web.b.ebscohost.com/ehost/pdfviewer/pdfviewer?sid=574b888b-4dbe4295-9a7a-b42198428f9a\%40sessionmgr104\&vid=3\&hid=129.

Hefetz, A., \& Warner, M. (2004). Privatization and Its Reverse: Explaining the Dynamics of the Government Contracting Process. Journal of Public Administration Research and Theory: J-PART, 14(2), 171-190. Retrieved from http://www.jstor.org/stable/3525868

Heinrich, C. (2011). Public management. In Mark Bevir (Ed.), The Sage Handbook of Governance (pp.252-268). Thousand Oaks, CA: Sage Publication.

Hicken, A., \& Selway, J. S. (2012). Forcing the Genie Back in the Bottle: Sociological Change, Institutional Reform, and Health Policy in Thailand. Journal of East Asian Studies, 12(1), 57-88.

Hirst, P. (2000). Democracy and Governance. In Jon Pierre (Ed.), Debating Governance- Authority, Steering and Democracy (pp.13-30). New York, NY: Oxford University Press.

Holmes, B. (2011). Citizens' engagement in policymaking and the design of public services (Report No. 1, 2011-12). Retrieved from http://parlinfo.aph.gov.au/parlInfo/download/library/prspub/942018/upload_binar y/942018.pdf;fileType=application/pdf\#search $=\% 222010 \mathrm{~s} \% 22$

Hood, C. (1991). A public management for all seasons? Public Administration, 69(1), 3-19. Retrieved from doi: 10.1111/j.1467-9299.1991.tb00779.x

Horwich, G. (2000). Economic Lessons of the Kobe Earthquake. Economic Development and Cultural Change, 48(3), 521-542. Retrieved from doi:10.1086/452609

Human Right Watch. (2016, January). Thailand events of 2015. World Report 2016. Retrieved from https://www.hrw.org/sites/default/files/thailand.pdf

International Association for Public Participation. (2014). IAP2's public participation spectrum. Retrieved from http://c.ymcdn.com/sites/www.iap2.org/resource/resmgr/foundations_course/IAP 2_P2_Spectrum_FINAL.pdf

International Crisis Group. (2014). A coup ordained? Thailand's prospects for stability. Asia Report N.263, December 3, 2014, Brussels: Belgium. Retrieved from https://d2071 andvip0wj.cloudfront.net/a-coup-ordained-thailand-sprospects-for-stability.pdf 
International Monetary Fund. (2017). Thailand World Economic Outlook Database. Retrieved from http://www.imf.org/external/pubs/ft/weo/2017/01/weodata/weorept.aspx?pr.x=61 $\&$ pr. $y=12 \&$ sy $=2006 \&$ ey $=2017 \&$ scsm $=1 \&$ ssd $=1 \&$ sort $=$ country $\& d s=. \& b r=1 \& c=5$ 78\&s=NID_NGDP\%2CLUR\&grp $=0 \& a=\#$ download

Iwilade, A. (2013). Crisis as opportunity: youth, social media and the renegotiation of power in Africa. Journal of Youth Studies, 16(8), 1054-1068. Retrieved from https://doi-org.proxy.lib.pdx.edu/10.1080/13676261.2013.772572

Kamnuansilpa, P., Wongthanavasu, S., \& Ando, H. (2013). Thailand decentralizes: local views. Khon Kaen, Thailand: Klung Nana Vithaya Limited Partnership

Kingdon, J. W. (2003). Agendas, alternative, and public policies. New York: Longman.

Kooiman, J. (2003). Governing as governance. Thousand Oaks, CA: SAGE Publications Inc.

Kreuzer, M. (2000). Electoral Mechanisms and Electioneering Incentives. Party Politics, 6(4), 487-504. Retrieved from https://doiorg.proxy.lib.pdx.edu/10.1177/1354068800006004006

Krieger, J. (2001). The Oxford Companion to Politics of the World: Oxford University Press. Retrieved from http://www.oxfordreference.com/view/10.1093/acref/9780195117394.001.0001/a cref-9780195117394.

Krueathep, W. (2004). Local government initiatives in Thailand: Cases and lessons learned. Asia Pacific Journal of Public Administration, 26(2), 217-239. Retrieved from http://dx.doi.org/10.1080/23276665.2004.10779294

Kynev, A. V. (2006). The Effects of "Maidan": Ukraine's Political System After the 2004 Crisis, Russian Politics \& Law, 44 (2), 28-38. Retrieved from http://dx.doi.org/10.2753/RUP1061-1940440202

Jikkham, P., Mala, D., \& Sattaburuth, A. (2015, September 21). PM launches 'people's state' policy. The Bangkok Post. Retrieved from http://www.bangkokpost.com/print/700048/

Jones, L. (June $5^{\text {th }}$, 2014). Thailand's Déjà-Coup, why the current military intervention is as doomed to fail as the last one was. The Diplomat. Retrieved from http://thediplomat.com/2014/06/thailands-deja-coup/

Jones, M. (2015). Which ASEAN country is the most competitive? The Economic Forum. Retrieved from https://www.weforum.org/agenda/2015/04/which-aseancountry-is-the-most-competitive/

Jung, K. H., Pongsomlee, A., Maksum, M., \& Park, T. K. (2003). Civil Society Response to Asian Crisis Thailand, Indonesia, and Korea. Seoul, Korea: ORUEM Publishing House.

Keyes, C. (2015). Trends in Southeast Asia. Democracy Thwarted: The Crisis of 
Political Authority in Thailand. Singapore: Institute of Southeast Asian Studies Publishing.

Khoman, S. (2005). Education: the key to long-term recovery? In Peter Warr (Ed.). Thailand beyond the crisis. New York, NY: Routledge Curzon.

Kickert, W. J.M. (1997). Public Governance in the Netherlands: An Alternative to Anglo-American 'Managerialism'. Public Administration, 75(4), 731-752.

Retrieved from http://doi:10.1111/1467-9299.00084

Klijn, E. H. (2002). Governing networks in the hollow state: contracting out, process management or a combination of the two? Public Management Review, 4(2), 149165. Retrieved from http://dx.doi.org/10.1080/14616670210130516

Krueathep, W. (2004). Local government initiatives in Thailand: Cases and lessons learned. Asia Pacific Journal of Public Administration, 26(2), 217-239. Retrieved from https://doi-org.proxy.lib.pdx.edu/10.1080/23276665.2004.10779294

Kuhonta, E. M. \& Sinpeng, A. (2014). Democratic Regression in Thailand: The Ambivalent Role of Civil Society and Political Institutions. Contemporary Southeast Asia: A Journal of International \& Strategic Affairs, 36(3), 333-355. Retrieved from doi:10.1355/cs36-3a

Kurlantzick, J. (2011) "Thailand: A Democratic Failure and Its Lessons for the Middle East." CFR.org. Council on Foreign Relations, 24 Mar. 2011. Retrieved from http://www.cfr.org/thailand/thailand-democratic-failure-its-lessons-middleeast/p24485

Lawton, A., \& Macaulay, M. (2014). Localism in practice: Investigating citizen participation and good governance in local government standards of conduct. Public Administration Review, 74(1), 75-83. Retrieved from http://onlinelibrary.wiley.com.proxy.lib.pdx.edu/doi/10.1111/puar.12161/epdf

Lewis, B., McCulloch, N., \& Sacks, A. (2016). Measuring Local Government Service Delivery Performance: Challenges and (PARTIAL) Solutions in Indonesia. Journal of International Development, 28(5), 808-817. Retrieved from 10.1002/jid.3106

Local Administration Act (1914). พระราชบัญญัติลักษณะการปกครองท้องที่ พ.ศ.๒๔๕ฒ [1914 Local Administration Act of Thailand]. Retrieved from http://web.krisdika.go.th/data/law/law2/\%C503/\%C503-20-2552-a0002.htm

Low, P. K. C. (2012). Leading successfully in Asia. New York, NY: Springer Science $\&$ Business Media.

Lieberman, E. S. (2012). The comparative politics of service delivery in developing countries. Retrieved from https://evanlieberman.files.wordpress.com/2014/01/thepolitics-of-service-delivery-paper_lieberman_reviseddec2012.pdf

Mackintosh, M. (1992). Partnership: issues of policy and negotiation. Local economy, 7(3), 210-224. Retrieved from https://doi:10.1080/02690949208726149

Manda, D. K., \& Mwakubo, S. (2013). Institutions and service delivery in Africa: An 
overview. Journal of African economies, ii4-ii15. Retrieved from https://academic-oup-com.proxy.lib.pdx.edu/jae/articleabstract/22/suppl_2/ii4/715140/Institutions-and-Service-Delivery-in-AfricaAn?redirectedFrom=fulltext

Mansrisuk, C. (2012). Decentralisation in Thailand and the Limits of The Functionalist Perspective of Institutional Reform. European Journal of East Asian Studies, 11(1), 71-97. Retrieved from DOI: 10.1163/15700615-20120007

March, J.G. \& Olsen, J.P. (1984). The new institutionalism: Organizational factors in political life. The American Political Science Review, 78(3), 734-749. Retrieved from doi:10.2307/1961840 . (1989). Rediscovering Institutions: The Organizational Basis of Politics. New York, NY: The Free Press: A Division of Macmillan, Inc. Marks, D. \& Lebel, L. (2016). Disaster governance and the scalar politics of incomplete decentralization: Fragmented and contested responses to the 2011 floods in Central Thailand. Habitat International, 52, 57-66. Retrieved from https://doi.org/10.1016/j.habitatint.2015.08.024

Marshall, A. R. C. \& Szep, J. (January 30 ${ }^{\text {th }}, 2014$ ). Insight: How Thaksin's meddling sparked a new Thai crisis for PM sister. Reuters. Retrieved from http://www.reuters.com/article/us-thailand-amnesty-insightidUSBREA0U00620140131

Mayne, J. \& Rieper, O. (2003). Collaborating for public service delivery: The implications for evaluation. In Andrew Gray, Bill Jenkins, Frans Leeuw, and John Mayne (Ed.), The Challenge for Evaluation, Collaborative in Public Services (pp. 105-130). New Brunswick, NJ: Transaction Publishers.

McCargo, D. (2000). Thailand: Crisis or reform? Asian Affairs, 31(2), 131-137. Retrieved from http://www-tandfonlinecom.proxy.lib.pdx.edu/doi/pdf/10.1080/738552626? needAccess=true . (2002). Democracy under stress in Thaksin's Thailand. Journal of Democracy, 13(4), 112-126. Retrieved from https://muse.jhu.edu/article/17242/pdf

McLaverty, P. (2011). Participation. In Mark Bevir (Ed.), the SAGE Handbook of Governance (pp. 402-418). Thousand Oaks, CA: SAGE Publications Inc.

Menkhaus, K. (2007). The Crisis in Somalia: Tragedy in Five Acts. African Affairs, 106(424), 357-390. Retrieved from http://www.jstor.org.proxy.lib.pdx.edu/stable/4496459

Michels, A. \& Graaf, L.D. (2010). Examining citizen participation: Local participatory policy making and democracy. Local Government Studies, 26(4), 477-491. Retrieve from DOI: 10.1080/03003930.2010.494101

Moe, T. (1984). The New Economics of Organization. American Journal of Political Science, 28(4), 739-777. Retrieved from http://doi:10.2307/2110997 
Muchadenyika, D. (2015). Land for Housing: A Political Resource - Reflections from Zimbabwe's Urban Areas. Journal of Southern African Studies, 41(6), 1219-1238. Retrieved from https://doiorg.proxy.lib.pdx.edu/10.1080/03057070.2015.1087163 . (2017). Civil society, social accountability and service delivery in Zimbabwe. Development Policy Review, 35(S2), 0178-0195. Retrieved from https://doi-org.proxy.lib.pdx.edu/10.1111/dpr.12242

Munger, F. (2007). Constitutional reform, legal consciousness, and citizen participation in Thailand. Cornell International Law Journal, 40(2), 455-75. Retrieved from http://scholarship.law.cornell.edu/cgi/viewcontent.cgi?article $=1702 \&$ context $=$ cilj

Munzwa, K., \& Wellington, J. (2010). Urban development in Zimbabwe: A Human settlement perspective. Theoretical and Empirical Researches in Urban Management, (14), 120-146. Retrieved from http://stats.lib.pdx.edu/proxy.php?url=http://search.proquest.com.proxy.lib.pdx.ed $\mathrm{u} /$ docview/233249626? accountid $=13265$

Musekiwa, N., \& Chatiza, K. (2015). Rise in resident associational life in response to service delivery decline by urban councils in Zimbabwe. Commonwealth Journal of Local Governance., 16(17), 120-136. Retrieved from http://dx.doi.org/10.5130/cjlg.v0i0.4489

Mutebi, A. M. (2006). Deliberative Civic Engagement at the Grassroots: An Exploration of Political Participation in Bangkok. Space \& Polity, 10(3), 279298. Retrieved from doi: $10.1080=13562570601110674$

Mydans, S. \& Fuller, T. (September 20, 2006). With premier at U.N., Thai military stages coup. New York Times: Asia-Pacific. Retrieved from http://www.nytimes.com/2006/09/20/world/asia/20thailand.html

Nagai, F., Funatsu, T., \& Kagoya, K. (2008). Central-local relationship in Thailand. In Nagai, F, Mektrairat, N. \& Funatsu, T. (eds.) Local Government in ThailandAnalysis of the Local Administrative Organization Survey, 1-30. Chiba, Japan: Institute of Developing Economics. Retrieved from http://www.ide.go.jp/English/Publish/Download/Jrp/pdf/147_2.pdf

Nagai, F., \& Kagoya, K. (2011). Decentralization as a Local Governance Innovation in Thailand. Innovative Trends in Public Governance in Asia, 16, 137.

Narayan, D., Chambers, R., Shah, M. K., \& Petesch, P. (2000). Voices of the Poor, Crying Out for Change. New York, NY: Oxford University Press

National Council for Peace and Order. (2014). The Announcement of the National Council for Peace and Order, No. 85/2014. Retrieved from http://library2.parliament.go.th/giventake/content_ncpo/ncpo-annouce85-2557.pdf Nelson, A. A., \& Balu, R. (2014). Local Government Responses to Fiscal Stress: 
Evidence from the Public Education Sector. Public Administration Review, 74(5), 601-614. Retrieved from http://onlinelibrary.wiley.com.proxy.lib.pdx.edu/doi/10.1111/puar.12211/epdf. Nishishiba, M., Jones, M., \& Kraner, M. (2014). Research Methods and Statistics for Public and Nonprofit Administrators. California, CA: Sage Publications, Inc.

Nishishiba, M. (2012). Local Government Diversity Initiatives in Oregon an Exploratory Study. State and Local Government Review, 44(1), 55-66. Retrieved from http://slg.sagepub.com.proxy.lib.pdx.edu/content/44/1/55.short Norton, E. (2012). Illiberal Democrats versus Undemocratic Liberals: The Struggle Over the Future of Thailand's Fragile Democracy. Asian Journal of Political Science, 20(1), 46-69.

Retrieved from https://doi org.proxy.lib.pdx.edu/10.1080/02185377.2012.673860

North, D. G. (1990). Institutions, institutional change and economic performance. New York, NY: Cambridge University Press . (1994). Economic Performance Through Time. The American Economic Review, 84(3), 359-368. Retrieved fromhttp://www.jstor.org.proxy.lib.pdx.edu/stable/2118057

Northouse, P. G. (2013). Leadership: Theory and practice (6th ed.). Thousand Oaks: SAGE. Oates, W. (1999). An Essay on Fiscal Federalism. Journal of Economic Literature, 37(3), 1120-1149. Retrieved from http://www.jstor.org/stable/2564874

Ockey, J. (2007). Thailand in 2006: Retreat to Military Rule. Asian Survey, 47(1), 133-140. Retrieved from http://doi:10.1525/as.2007.47.1.133. .(2009). Thailand in 2008: Democracy and Street Politics. Southeast Asian Affairs, 315-333.

OECD. (n.d.). OECD Better life index, civic engagement. Retrieved from http://www.oecdbetterlifeindex.org/topics/civic-engagement/ (2011). Together for Better Public Services: Partnering with Citizens and Civil Society, OECD Public Governance Review. OECD Publishing. Retrieved from http://dx.doi.org/10.1787/9789264118843-en

O’Neil, T., Cammack, D., Kanyongolo, E., Mkandawire, M.W., Mwalyambwire, T., Welham, B.and Wild, L. (2014). Fragmented governance and local service delivery in Malawi. London: ODI. Retrieved from https://www.odi.org/sites/odi.org.uk/files/odi-assets/publications-opinionfiles/8943.pdf

Osborne, S.P. (2006). The new public governance? Public Management Review, 8(3), 377-387. Retrieved from http://dx.doi.org/10.1080/14719030600853022

Osborne, D. (1993). Reinventing Government. Public Productivity \& Management Review, 16(4), 349-356. Retrieved from http://doi:10.2307/3381012

Osborne, D. \& Gaebler, T. (1993). Reinventing government: how the entrepreneurial spirit is transforming the public sector. New York, NY: A Plum Book

Pahad, E. (2005). Political participation and civic engagement. Progressive Politics, 
4(2), 21-26. Retrieved from http://www.policy-

network.net/uploadedFiles/Publications/Publications/Pahad-final.pdf.

Painter, M. (2004). The Politics of Administrative Reform in East and Southeast Asia: From Gridlock to Continuous Self-improvement? Governance, 17(3), 361-386. Retrieved from doi:10.1111/j.0952-1895.2004.00250.x

Paribatra, S. (1993). State and society in Thailand: How fragile the democracy? Asian Survey, 33(9), 879-893. Retrieved from http://www.jstor.org.proxy.lib.pdx.edu/stable/pdf/2645235.pdf

Pathmanand, U. (2008). A different coup d'état? Journal of Contemporary, 124-142, 38(1). Retrieved from http://www-tandfonlinecom.proxy.lib.pdx.edu/doi/pdf/10.1080/00472330701651994?needAccess $=$ true

Patton, M. Q. (1999). Enhancing the quality and credibility of qualitative analysis. Health Services Research, 34(5), 1189-1208.

Peters, B.G. (2011). Institutional theory. In Mark Bevir (Ed.), The Sage Handbook of Governance (pp. 78-90). London, England: Sage Publication. . (2012). Institutional theory in political science: The new institutionalism ( $3^{\text {rd }}$ ed.). New York, NY: The Continuum International Publish Group.

Peters, B., \& Pierre, J. (1998). Institutions and Time: Problems of Conceptualization and Explanation. Journal of Public Administration Research and Theory: J-PART, 8(4), 565-583. Retrieved from http://www.jstor.org.proxy.lib.pdx.edu/stable/1181635

Phongpaichit, P. \& Baker, C. (February $3^{\text {rd }}$, 2005). Thailand's election, Thaksin's way: A formidable success story, though with some worrying signs. The Economist. Retrieved from http://www.economist.com/node/3623091

Pollitt, C. (2003). Joined-up Government: a Survey. Political Studies Review, 1(1), 34-49. Retrieved from doi:10.1111/1478-9299.00004

Pongsudhirak, T. (2008). Thailand since the coup. Journal of Democracy, 19(4), 140153. Retrieved from http://stats.lib.pdx.edu/proxy.php?url=http://search.proquest.com.proxy.lib.pdx.ed $\mathrm{u} /$ docview/195560912? accountid=13265 . (2014). The roots of Thailand's political polarization in comparative perspective. Discussion paper prepare for the 2014 Annual Conference on Taiwan Democracy. Retrieved from file:///C:/Users/sirisak/Downloads/pongsudhirak.thaipolpolarization-cddrl17oct2014\%20(1).pdf

Pineda, M. (May 18, 2010). Thailand "Black May": 1992 VS. 2010. Economonitor. Retrieved from http://www.economonitor.com/analysts/2010/05/18/thailandsblack-may-1992-vs-2010/

Prasirtsuk, K. (2010). Thailand in 2009: Colored by Turbulence. Asian Survey, 50(1), 203-210. Retrieved from doi:10.1525/as.2010.50.1.203 
Putnam, R. D. (1993). Making democracy work: Civic traditions in modern Italy. Princeton, NJ: Princeton University Press.

Reschovsky, A. (2004). The impact of state government fiscal crises on local governments and schools. State \& Local Government Review, 86-102. Retrieved from http://www.jstor.org.proxy.lib.pdx.edu/stable/pdf/4355362.pdf?acceptTC=true

Renn, O., Klinke, A., \& Van Asselt, M. (2011). Coping with Complexity, Uncertainty and Ambiguity in Risk Governance: A Synthesis. Ambio, 40(2), 231-246. Retrieved from http://www.jstor.org/stable/41417271

Rhodes, R.A.W. (1996). The new governance: Governing without government. Political Studies, 44(4), 652-667. Retrieved from http://web.b.ebscohost.com/ehost/pdfviewer/pdfviewer?sid=30286386-6b724059-b2f7-427e9b773982\%40sessionmgr102\&vid=3\&hid=128 . (2007). Understanding governance: Ten years on. Organization studies, 28(8), 1243-1264. Retrieved from http://journals.sagepub.com/doi/pdf/10.1177/0170840607076586

Robinson, M. (2007). Does Decentralisation Improve Equity and Efficiency in Public Service Delivery Provision? IDS Bulletin, 38(1), 7-17. Retrieved from doi:10.1111/j.1759-5436.2007.tb00333.x

Rodrigues, M., Tavares, A., \& Araújo, J. (2012). Municipal Service Delivery: The Role of Transaction Costs in the Choice between Alternative Governance Mechanisms. Local Government Studies, 38(5), 615-638. Retrieved from https://doi-org.proxy.lib.pdx.edu/10.1080/03003930.2012.666211

Rondinelli, D. (1981). Government decentralization in comparative perspective: Theory and practice in developing countries. International Review of Administrative Sciences, 47(2), 133-145. Retrieved from https://doiorg.proxy.lib.pdx.edu/10.1177/002085238004700205

Saito, F. (2011). Decentralization. In Mark Bevir (Ed.), The Sage Handbook of Governance (pp. 484-500). Thousand Oaks, CA: Sage Publication.

Sethapramote, Y. (March 28, 2014). The economic consequences of Thailand's political crisis. The Nation: Economy, Business \& Tourism. Retrieved from http://www.nationmultimedia.com/news/business/EconomyAndTourism/3023026 8

(April 7, 2015). Economic recovery is slow, but it's still going. The Nation: Economy, Business \& Tourism. Retrieved from http://www.nationmultimedia.com/news/business/EconomyAndTourism/3025752 4

Shah, A., Thompson, T., \& Zou, H. F. (2004). The impact of decentralization on service delivery corruption, fiscal management and growth in developing and emerging market economics; A synthesis of empirical evidence, CESifo DICE Report, 10-4. Retrieved from http://hdl.handle.net/10419/166793 
Sirianni, C. (2009). Investing in democracy, engaging citizens in collaborative governance. Washington, D.C.: Brookings Institution Press.

Stake, R. (1995). The art of case study research. Thousand Oaks, CA: Sage.

State Administration Act (1991). พระราชบัญญัติระเบียบบริหารราชการแผ่นดิน พ.ศ. ๒๕์๒ [State

Administration Act 1991]. Retrieved from

http://www.krisdika.go.th/wps/wcm/connect/1e7cea804b9e9ad2889efdea72b7e93

8/STATE+ADMINISTRATION+ACT\%2C+B.E.+2534+\%281991\%29.pdf?MO

$\mathrm{D}=\mathrm{AJPERES} \& C A C H E I D=1 \mathrm{e} 7 \mathrm{cea} 804 \mathrm{~b} 9 \mathrm{e} 9 \mathrm{ad} 2889 \mathrm{efdea} 72 \mathrm{~b} 7 \mathrm{e} 938$

Stenberge, C. W. (2011). Coping with Crisis: How Are Local Governments

Reinventing Themselves in the Wake of the Great Recession? A Policy Issue

White Paper Prepared on Behalf of the ICMA Governmental Affairs and Policy

Committee, Washington, DC: The International City/County Management

Association (ICMA). Retrieved from

http://icma.org/en/icma/knowledge_network/documents/kn/Document/303228/Co ping_with_Crisis.

Stern, L.W. \& Reve, T. (1980). Distribution channels as political economies: A

Framework for comparative analysis. Journal of Marketing, 44(3), 52-64.

Stoker, G. (1998). Governance as theory: five propositions. International social science journal, 50(155), 17-28. Retrieved from doi:10.1111/1468-2451.00106

Sudhipongpracha, T. (2014). Local emergency management in decentralized

Thailand: Analysis of Thai municipal administrators' perceptions of democratic accountabilities in the post-decentralization era. Journal of Asian Public Policy, 7(3), 259-274. Retrieved from https://doi-

org.proxy.lib.pdx.edu/10.1080/17516234.2014.922146 . (2016). Citizen politics from a citizens' perspective, a case of

Khon Kaen City Assembly. Khon Kaen, KK: Klangnana Press

Sudhipongpracha, T., \& Wongpredee, A. (2015). Disequalizing Equalization Grant:

An Assessment of the Relationship Between Equalization Grant and Local Fiscal

Capacity in Northeast Thailand. Asian Affairs: An American Review, 42(1), 1-21.

Retrieved from doi:10.1080/00927678.2015.999515 . (2016). Decentralizing decentralized

governance: Community empowerment and coproduction of municipal public works in Northeast Thailand. Community Development Journal, 51(2), 302-319.

Retrieved from

https://ill.lib.pdx.edu/illiad.dll?Action $=10 \&$ Form $=75 \&$ Value $=449442$

Sussangkarn, C. \& Nikomborirak, D. (2016). Thailand's Long-Term Growth:

Aspiration, Reality and Challenges. (2016). Asian Economic Papers, 15(2),

23-43. Retrieved from

https://ill.lib.pdx.edu/illiad.dll?Action $=10 \&$ Form $=75 \&$ Value $=449443$

Taleb, N. N. (2012). Antifragile: things that gain from disorder. New York, NY:

Random House 
Teske, P. (1991). Interests and Institutions in State Regulation. American Journal of Political Science, 35(1), 139-154. Retrieved from http://doi:10.2307/2111441

Tschirhart, M., Amezcua, A., \& Anker, A. (2009). Resources sharing: how resource attributes influence sharing system choices. In Rosemary O'Leary and Lisa Blomgren Bingham (Ed.), the Collaborative Public Manager (pp.15-29).

Washington, D.C.: Georgetown University Press

Thailand. Const. (Interim) $\S 44$, B.E. 2557 (2014). Retrieved from http://www.krisdika.go.th/wps/wcm/connect/c6127f004ea9e1cb94fb9d1b6e11f09 9/Constitution+of+the+Kingdom+of+Thailand+\%28Interim\%29\%2C+B.E. +2557 $+\% 282014 \% 29$.pdf?MOD=AJPERES $\&$ CACHEID=c6127f004ea9e $1 \mathrm{cb} 94 \mathrm{fb} 9 \mathrm{~d} 1 \mathrm{~b} 6$ e11f099

UNDP. (2016). Citizen engagement in public service delivery, the critical role of public affairs. Singapore: Global Center for Public Service Excellence. Retrieved from http://www.undp.org/content/dam/undp/library/capacitydevelopment/English/Singapore\%20Centre/GCPSE_CitizenEngagement_2016.pd $\mathrm{f}$

Unger, D. \& Mahakanjana, C. (2016). Decentralization in Thailand. Journal of Southeast Asian Economies (JSEAE), 33(2),172-187. Retrieved from http://muse.jhu.edu/article/628364.

United Nations. (2004). The kingdom of Thailand, public administration country profile. Division for Public Administration and Development Management, Department of Economics and Social Affairs, United Nations. Retrieved from http://unpan1.un.org/intradoc/groups/public/documents/un/unpan023244.pdf . (2016, August 19). Concerned by curbs on free expression in Thailand, UN rights office calls for 'prompt return to civilian rule'. UN News Center. Retrieved from http://www.un.org/apps/news/story.asp?NewsID=54722\#.WQ52ztIrJdj

Varanyuwatana, S. (2006). Decentralization and the budget for social services at Tambon Administration Level, Thailand. Bangkok, BKK: FSPN Network company limited

Waitoolkiat, N., \& Chambers, P. (2015). Political Party Finance in Thailand Today: Evolution, Reform, and Control. Critical Asian Studies, 47(4), 611-640. Retrieved from doi:10.1080/14672715.2015.1091211

Wamsley, G., \& Zald, M. (1973). The Political Economy of Public Organizations. Public Administration Review, 33(1), 62-73. Retrieved from http://doi:10.2307/974786

Wart, M. V. (2003), Public-Sector Leadership Theory: An Assessment. Public Administration Review, 63(2), 214-228. Retrieved from doi:10.1111/15406210.00281

Whiteman, H. (2014, May 22). Thailand wakes to military rule: What it means. $C N N$ 
World. Retrieved from http://www.cnn.com/2014/05/20/world/asia/thailandmartial-law-explainer/index.html?hpt=bosread

Wongpredee, A. \& Sudhipongpracha, T. (2014). The politics of intergovernmental transfers in Northeast Thailand. Journal of Developing Societies, 30(3): 343-363. Retrieved from doi: 10.1177/0169796X14536974

World Bank. (October 18, 2016). Overcoming hard times: Accompanying Madagascar's poorest through crises. The World Bank-What We do. Retrieved from http://www.worldbank.org/en/results/2016/10/18/overcoming-hard-timesaccompanying-madagascars-poorest-through-crises . (2012). Improving service delivery, Thailand: Public Finance

Management Report. Retrieved from http://documents.worldbank.org/curated/en/993671468118138134/pdf/674860ES W0P1180019006020120RB0EDITS.pdf

Yaxley, L. (2006, September 20). Downer concerned by overthrow of Thai govt. $A B C$ Local Radio. Retrieved from http://www.abc.net.au/am/content/2006/s1745062.htm

Yilmaz, S., Beris, Y., \& Serrano-Berthet, R. (2008). Local government discretion and accountability: A diagnosis framework for local governance. Washington, DC: Social Development, the World Bank. Retrieved from http://siteresources.worldbank.org/EXTSOCIALDEVELOPMENT/Resources/24 4362-1193949504055/LocalGovernmentDiscretionandAccountability.pdf

Yueh, L. (May 23, 2014). Thailand coup: Effect on the market. BBC News-Business. Retrieved from http://www.bbc.com/news/business-27537580

Yin, R. K. (2014). Case Study Research Design and Methods. California, CA: Sage Publications, Inc. 


\section{Appendix A}

\section{Graphical Representation of Findings: How National Political Crisis Creates Threats to}

Local Government Service Delivery

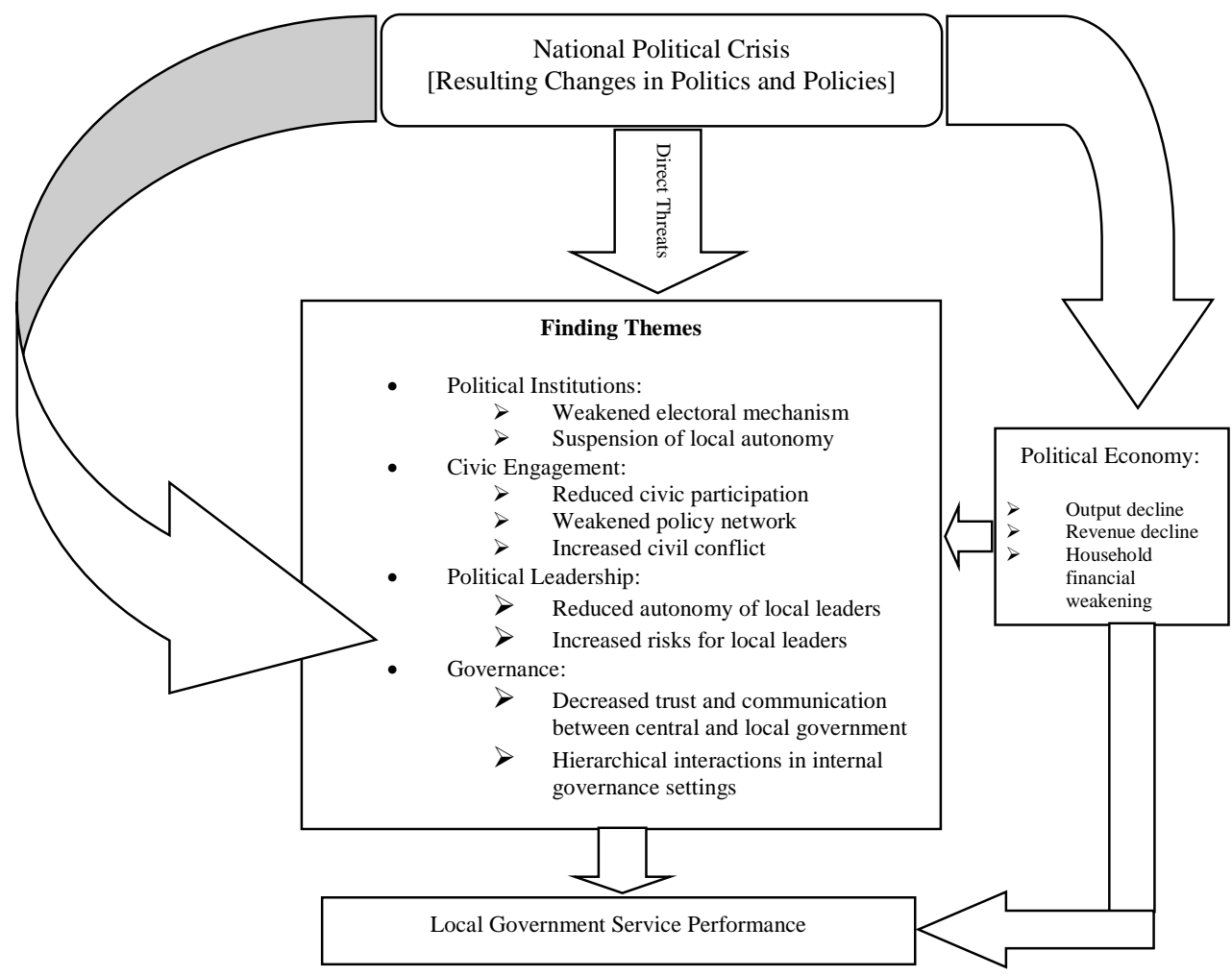




\section{Appendix B}

Graphical Representation of Findings: How National Political Crisis Creates Opportunities to Local Government Service Delivery

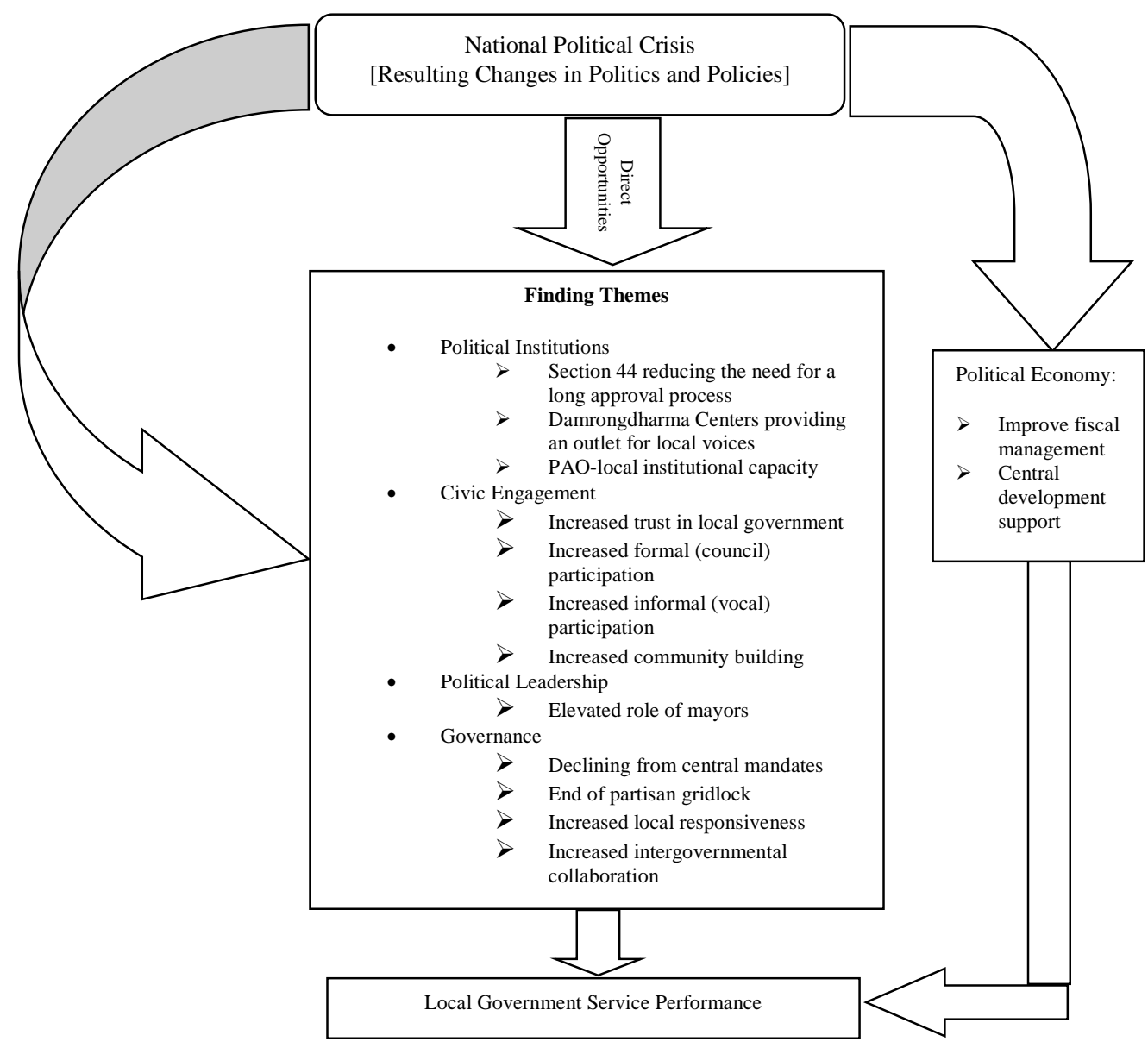




\section{Appendix C}

\section{Interview Guide}

\section{A: Face-to Face, In-depth Interview Guide}

\section{Part I: Introduction}

- Introduce myself, educational background, and research objective.

- Introduction of key informant, position, and job responsibilities.

- Explain informed consent, ask them to sign the form, and ask for a permission to record the interview.

\section{Part II: Questions regarding general information and political and administrative} background of the participant [10 minutes]

- "Please tell me about your administrative and political experience."

- "How long have you serve in this position?"

- "What are your political and administrative experiences since 2006?"

Part III: Questions regarding the effects of national political crises, mediated by five mechanisms, on local government service delivery [30 minutes]

Questions regarding political institutions:

- "Could you please describe to me the relationship and influence of political institutions (e.g. constitution, laws, election, and political parties) and your local government and local community since 2006?"

- "How do you see political crisis in Thailand since 2006 (change in national politics and national policies) affecting local government service delivery and your local community? Any example? Can you tell me the reasons why?"

\section{Questions regarding civic engagement:}

- Could you share with me about civic engagement in your local government and your local community since 2006 ?

- How do you see Thailand's post-2006 political turmoil affects civic engagement, thus resulting effective or ineffective local service delivery? Any example? Can you tell me the reasons why?

\section{Questions regarding political leadership:}

- Can you share with me your thoughts about how the mayor and local officers responded to the national political crisis in order to maintain local service delivery?

- How do you see Thailand's post-2006 national political crises affecting local political leadership in your local government and community? Any example? 


\section{Questions regarding governance:}

- "Please talk about your perceptions about current governing process of local government and how does local government build collaboration and network in the midst of crisis in order to maintain quality of public service."

- "How do you see the national political crisis since 2006 affecting collaboration and intergovernmental relationship within your local governments? Any example? Can you tell me the reasons why?"

\section{Questions regarding political economy:}

- "Can you share with me your thoughts on the economic status of your local community since 2006?" How about

- "How do you see the ongoing national political crisis becoming a factor that may impact economy in your local community? And how its effects induce effective or ineffective of local service delivery? Any examples? Can you tell me the reasons why?"

\section{Part IV: Wrap up [10]}

- "Could you please tell me any points we have not discussed that you think are important?"

- "Thank you for participating this interview."

- Check the audio recorder and verify the completed consent form. 


\section{B: Focus Group Discussion Guide [Heads of Municipal Department]}

\section{Part I: Introduction}

- Introduce myself, educational background, and research objective.

- Introduction of participants, positions, and job responsibilities.

- Explain informed consent, ask them to sign the form, and ask for a permission to record the interview.

\section{Part II: Discussions}

1. [5 minutes] You play an important role in local government as the government officials. The political crisis since 2006 that has occurred at the national level might affect your organization and local public service delivery. So, I would like to hear some stories that you perceived from the media and the actual situation.

- We will start sharing about the general issues regarding the crisis, however if you can specify the issue that is related to local government and you frequently hear or watch the news from the medias. I provide you a card; you can write those issues down on that card. After that I will allow each of you to share your story.

1a. [5 minutes] Have you followed the national political crisis? Let's share your stories.

2. [10 minutes] This is a good start. We learn from the stories that you share, especially the issues that impact local government administration and local public service delivery. Let's talk more about the effect of prolonged national political crisis on local public service delivery through process of local governance since 2006. Do you think the crisis affects the structure, function, six major duties of local government? Please specify the occurrences during 2006-present.

- Please feel free to share your thoughts. You may talk about the structure first and then talk about the function later. Feel free to share as much as you can, especially the issues that have had a direct impact on your local government and your responsibilities.

2a. [10 minutes] Do you see yourself as key player in the local government operation. During the prolonged political crisis, do you think local 
government can provide continue to provide the services during the midst of the crisis? Why or why not?

2b. [5 minutes] I would like to know the impact of the crisis on your duties. Do you think your duties are affected from the crisis? How?

2c. [10 minutes] there are several governing factors that can be affected by the crisis, for example, political institutions, leadership, civic engagement, collaboration and network, and fiscal management. Do you think the political crisis at the national level impacts these governing factors? Do you think these governing factors affect local public service delivery and how?

2d. [5 minutes] Do you think the political crisis is considered a positive or negative influence on local government management and public service delivery? Why?

3. [5 minutes] Crisis management strategy is also a governing tool in the modern organization. How does local government respond crisis?

- Let's share your experience about the crisis management strategies that you employ to deal with the political crisis. You can also mention about its outcome and the way to improve that strategy.

4. [5 minutes] In ending, could you please tell me any points we have not discussed that you think are important. Take a moment and I would like to hear from each of you by going around the table.

- Thank you for participating this focus group interview.

- Check the audio recorder and consent form 


\section{C: Focus Group Discussion Guide [Local Resident and Community Leader]}

\section{Part I: Introduction}

- The moderator commences an interview by introducing name, background, and research objective, and then allows each participant to introduce selves by first name, position, and role in community.

- Explain the informed consent to the participants and ask them to sign the form.

\section{Part II: Discussions}

1. [5 minutes] You play an important role as the stakeholders in local government, the political crisis that currently occurs at the national level since 2006 might affect your everyday life and public service delivery from local government. So, I would like to hear some stories that you perceived from the media and the actual situation.

- We will start sharing about the general issues regarding the crisis, however if you can specify the issue that is related to your own experience on local government and you frequently hear or watch the news from the medias. I provide you a card, you can write those issues down on that card. After that I will allow each of you to share your story.

1a. [5 minutes] Do you follow the national political crisis? Let's share about your story.

2. [10 minutes] This is a good start. We learn from the stories that you share, especially the issues that impact your community and local public service delivery. Do you think the political crisis affects your community and local public services? Please specify the occurrences during 2006-present.

- Please feel free to share your experiences. Feel free to share as much as you can, especially the issue that has a direct impact on your community and local public service delivery.

2a. [10 minutes] You are the key stakeholders in local government. During the prolonged crisis, do you think local government can provide you the services as usual during the midst of the crisis? Why?

$2 b$. [ 5 minutes] There are several governing factors that can be affected by the crisis, for example, leadership, public engagement, and network. Do you 
think during the national political crisis the local government has a crisis in these factors?

2c. [10 minutes] Do you think the political crisis is considered a positive or negative effect on local governance and your community? Why?

3. [10 minutes] I think the crisis management strategy is also the governing tool in modern organization. I would like to hear from you that do you know how local government responds the crisis? And how does your community involve in the crisis management process?

- Let's share your experience about the crisis management strategies that you see the local government use them to deal with the political crisis.

- You can also mention about its outcome and the way to improve that strategy. I also would like to know the level of involvement in crisis management process.

5. [5 minutes] In ending, could you please tell me any points we have not discussed that you think are important. Take a moment and I would like to hear from each of you by going around the table.

- Thank you for participating this focus group interview.

- Check the audio recorder and consent form 


\section{Appendix D}

\section{Interview Guide [In Thai]}

\section{คำถามสัมภาษณ์เดี่ยวเชิงลึก}

\section{ส่วนที่ 1 : บทนำ}

- ผมเริ่มต้นการสัมภาษณ์ด้วยการแนะนำข้อมูลของตนเองที่เกี่ยวข้องกับการศึกษา เป้าหมายการวิจัย และ หลังจากนั้นก็เปิดโอกาสให้ผู้ให้สัมภาษณ์ได้แนะนำตัวเองและตำแหน่งหน้าที่รับผิดชอบในท้องถิ่น

- อธิบายข้อมูลเกี่ยวกับการกรอกแบบฟอร์มยินยอมให้สัมภาษณ์และแจ้งผู้ให้สัมภาษณ์ลงนามใน แบบฟอร์มนั้นหากยินดีร่วมการสัมภาษณ์ นอกจากนั้นขออนุญาตบันทึกเสียงขณะสัมภาษณ์ ส่วนที่ 2 : ข้อมูลทั่วไปและข้อมูลเกี่ยวกับประสบการณ์ทางการเมืองและการบริหารองค์กรปกครองส่วนท้องถิ่น (10 นาที)

- อยากให้ท่านได้โปรดเล่าถึงประสบการณ์การทำงานด้านการเมืองและการบริหารท้องถิ่นครับ

- ท่านได้ทำงานในตำแหน่งนี้นานเท่าไหร่แล้วครับ

- ท่านมีประสบการณ์การเมืองและการบริหารท้องถิ่นนับตั้งแตปี 2549 เป็นอย่างไรบ้างครับ ส่วนที่ 3: ผลของสภาวะวิกฤติการเมืองที่ส่งผลต่อปัจจัยแทรกซ้อน 5 ประการที่มีผลต่อสัมฤทธิผลการบริการ สาธารณะขององค์กรปกครองส่วนท้องถิ่น (30 นาที)

สถาบันการเมือง:

- ขอให้ท่านเล่าถึงความสัมพันธ์และอิทธิพลของสถาบันทางการเมือง อาทิ รัฐธรรมนูญ กฎหมาย การ เลือกตั้ง และพรรคการเมือง นับตั้งแตีปี 2549 ที่มีต่อองค์กรปกครองท้องถิ่นของท่านและต่อชุมชนของ ท่าน

- ท่านมองวิกฤติการเมืองไทยตั้งแต่ปี 2549 (การเปลี่ยนแปลงทางการเมืองและนโยบายระดับชาติ) ส่งผล กระทบต่อการบริการสาธารณะขององค์กรปกครองส่วนท้องถิ่นและต่อชุมชนท้องถิ่นของท่านอย่างไร บ้าง ยกตัวอย่างประกอบได้ไหมครับ และท่านช่วยให้เหตุผลได้ไหมครับว่าทำไมถึงเป็นเช่นนั้น การมีส่วนร่วมของภาคประชาชน:

- อยากให้ท่านได้เล่าถึงสภาวะการมีส่วนร่วมของภาคประชาชนในการดำเนินงานของท้องถิ่นและการ บริการสาธารณะ นับตั้งแต่เกิดวิกฤติการเมือง 2549

- ท่านคิดว่าวิกฤติการเมือง 2549 จวบจนถึงปัจจุบันส่งผลต่อการมีส่วนร่วมของภาคประชาชนอย่างไร บ้าง และผลดังกล่าวส่งผลต่อการมีประสิทธิภาพหรือไม่มีประสิทธิภาพในการบริการสาธาณะของ ท้องถิ่นอย่างไรบ้าง ช่วยยกตัวอย่างได้ไหมครับ และช่วยบอกได้ไหมครับว่าด้วยเหตุใดจึงเป็นเช่นนั้น 


\section{ภาวะผู้นำทางการเมือง:}

- อยากให้ท่านช่วยเล่าถึงความคิดเห็นของท่านเกี่ยวกับว่า นายกเทศมนตรีและบุคลากรท้องถิ่น ตอบสนองหรือรับมือกับวิกฤติการเมืองอย่างไร เพื่อที่จะรักษาและยังคงการให้บริการสาธารณะไว้ ดังเดิม

- ท่านคิดว่าวิกฤติการเมืองนับแต่ปี 2549 ถึงปัจจุบันส่งผลต่อภาวะผู้นำทางการเมืองในท้องถิ่นและชุมชน ของท่านอย่างไร ลองยกตัวอย่างให้ฟังได้ไหมครับ

การบริหารท้องถิ่น:

- ท่านช่วยเล่าได้ไหมครับว่าสภาวะการบริหารของท้องถิ่นท่านปัจจุบันเป็นอย่างไรบ้าง และท่านได้สร้าง การประสานงานร่วมหรือสร้างเครือข่ายเพื่อที่จะช่วยรักษาและคงไว้ซึ่งการบริการสาธารณะในท้องถิ่น ของท่านนับตั้งแต่เกิดวิกฤติการเมือง อย่างไรบ้าง

- ท่านคิดว่าวิกฤติการเมืองตั้งแต่ปี 2549 ส่งผลต่อความสัมพันธ์ภายในโครงสร้างรัฐกับท้องถิ่นของท่าน อย่างไรบ้าง พอจะเล่าตัวอย่างไหมครับ ท่านคิดว่าทำไมถึงเกิดแบบนั้นขึ้นครับ

\section{เศรษฐศาสตร์การเมือง:}

- ท่านช่วยเล่าได้ให้ฟังได้ไหมครับว่า ท่านเห็นสภาพเศรษฐกิจในชุมชนท้องถิ่นของท่านเป็นอย่างไรบ้าง นับแต่วิกฤติการเมือง 25549 จวบถึงปัจจุบัน

- ท่านคิดว่าวิกฤติการเมืองที่กำลังเกิดอยู่ขณะนี้สามารถเป็นปัจจัยที่จะส่งผลต่อเศรษฐกิจในชุมชนท้องถิ่น ของท่านได้อย่างไร และผลกระทบที่เกิดขึ้นจะส่งผลต่อประสิทธิภาพหรือความไม่มีประสิทธิภาพใน การบริการสาธารณะของท้องถิ่นอย่างไร ลองยกตัวอย่าง และบอกเหตุผลได้ไหมครับว่าทำไมจึงเป็น เช่นนั้น

\section{ส่วนที่ 4: สรุปปิดท้ายการสัมภาษณ์ (10 นาที)}

- ท่านพอจะมีประเด็นอะไรอื่นๆ อีกไหมครับที่ท่านอยากจะแลกเปลี่ยนหรือประเด็นที่ผมไม้ได้กล่าวถึง ในครั้งนี้ ซึ่งท่านเห็นว่ามีความสำคัญ

- ขอบพระคุณท่านมากนะครับสำหรับการให้สัมภาษณ์

- ตรวจสอบความเรียบร้อยของการบันทึกเสียงและการกรอกแบบฟอร์มยินยอมให้สัมภาษณ์ 


\section{คำถามสัมภาษณ์การประชุมกลุ่ม สำหรับผู้อำนวยการกองและหัวหน้าส่วนงานในเทศบาล ส่วนที่ 1: บทนำ}

- ผมเริ่มต้นการสัมภาษณ์ด้วยการแนะนำข้อมูลของตนเองที่เกี่ยวข้องกับการศึกษา เป้าหมายการวิจัย และ หลังจากนั้นก็เปิดโอกาสให้ผู้ให้สัมภาษณ์ได้แนะนำตัวเองและตำแหน่งหน้าที่รับผิดชอบในท้องถิ่น

- อธิบายข้อมูลเกี่ยวกับการกรอกแบบฟอร์มยินยอมให้สัมภาษณ์และแจ้งผู้ให้สัมภาษณ์ลงนามใน แบบฟอร์มนั้นหากยินดีร่วมการสัมภาษณ์ นอกจากนั้นขออนุญาตบันทึกเสียงขณะสัมภาษณ์

\section{ส่วนที่ $2:$ คำถามสัมภาษณ์}

1. ท่านในฐานะที่เป็นข้าราชการท้องถิ่น ท่านมีบทบาทสำคัญในองค์กรปกครองส่วนท้องถิ่น ซึ่งผมคิดว่าวิกฤติ การเมืองที่เกิดขึ้นในระดับชาติลากยาวมาตั้งแต่ปี 2549 อาจจะส่งผลกระทบต่อหน่วยงานของท่านรวมถึง หน้าที่ของท่านด้วย โดยเฉพาะที่เกี่ยวข้องกับการให้บริการสาธารณะ ดังนั้นผมอยากจะฟังเรื่องราวต่างๆที่ เกิดขึ้นเกี่ยวกับวิกฤติการเมืองไทยและผลกระทบทีเกิดขึ้น ที่ท่านอาจจะได้รับข้อมูลจากสื่อต่างๆ หรือท่าน อาจจะประสบด้วยตนเอง (5 นาที)

เราจะเริ่มการสนทนาโดยให้ทุกท่านได้แลกเปลี่ยนความเห็นเกี่ยวกับสภาวะวิกฤติการเมือง และ หากท่านสามารถระบุประเด็นที่มีส่วนเกี่ยวพันกับองค์กรปกครองส่วนท้องถิ่น ที่ท่านเคยได้รับรู้มาจาก แหล่งต่างๆ ไม่ว่าจะเป็นจากข่าวหรือสื่อต่างๆ ผมจะแจกแผ่นกระดาษโพสอิทให้ทุกท่านได้เขียนประเด็นที่ ท่านรับรู้เกี่ยวกับภาวะวิกฤติการเมืองในทัศนะของท่าน ลงในกระดาษ และหลังจากนั้นผมจะให้แต่ละท่าน ได้ร่วมแลกเปลี่ยนความเห็น

1. ท่านได้ติดตามข่าวเกี่ยวกับวิฤติการเมืองไทยบ้างไหมครับ เรามาแลกเปลี่ยนกันในประเด็นนี้ กันนะครับ (5 นาที)

2. นี่เป็นการเริ่มต้นการสนทนาที่ดีมากเลยนะครับ พวกเราได้เรียนรู้จากเรื่องราวที่เกิดขึ้นที่ทุกท่านได้ร้วม แลกเปลี่ยน โดยเฉพาะเรื่องการบริหารงานท้องถิ่นและการให้บริการสาธารณะ ต่อไปเรามาคุยลงลึกถึง ผลกระทบของภาวะวิกฤติการเมืองระดับชาติที่ส่งผลต่อการบริการสาธารณะของท้องถิ่นกันนะครับ ท่านคิด ว่าวิกฤติการเมืองที่เกิดขึ้น ส่งผลกระทบต่อโครงสร้าง การบริหาร และหน้าที่หลักของท้องถิ่นทั้ง 6 ประการ ไหมครับ อยากให้ท่านได้ระบุเป็นชัดๆที่เกิดขึ้นในห้วงตั้งแตปปี 2549 ถึงปัจจุบันครับ (10 นาที)

ท่านสามารณแลกเปลี่ยนประเด็นที่ท่านอยากนำเสนอได้ตามสะดวกเลยนะครับ ท่านอาจจะพูคถึง ประเด็นโครงสร้างก่อนหรือการบริหาร หรือหน้าที่ ก่อนก็ได้ครับ รบกวนทุกท่านแลกเปลี่ยนและนำเสนอ ให้ได้มากที่สุดเท่าที่ท่านต้องการครับนะครับ โดยผมเน้นประเด็นที่ส่งผลกระทบโดยตรงต่อความรับชอบ การบริการสาธารณะของท้องถิ่น 
2a. ท่านเป็นกลไกที่สำคัญมากในการบริหารท้องถิ่น ในช่วงที่เกิดวิกฤติการเมืองระดับชาติ ท่าน คิดว่าท้องถิ่นยังคงสามารถให้บริการสาธารณะได้เช่นเดิมไหม ทำไมเป็นเช่นนั้นครับ (10 นาที)

2 b. ผมอยากทราบว่าวิกฤติการเมืองส่งผลต่อหน้าที่ของท่านในการบริการสาธารณะและของ ท้องถิ่นอย่างไรบ้าง ท่านคิดว่าหน้าที่ของท่านได้รับผลกระทบบ้างไหม มีผลอย่างไรบ้าง (5 นาที)

2c. มีหลายปัจจัยทางการบริหารที่อาจจะได้รับผลกระทบจากวิกฤติการเมืองที่ลากยาว เช่น สถาบันการเมือง ภาวะผู้นำ การมีส่วนร่วมของภาคประชาชน การประสานความร่วมมือและเครือข่าย การ บริหารการเงินการคลัง ตลอดจนสภาพเศรษฐกิจ ท่านคิดว่าวิกฤติการเมืองระดับชาติส่งผลต่อปัจจัยแทรก ซ้อนเหล่านี้ไหม และท้ายสุดปัจจัยเหล่านี้ที่ได้รับผลกระทบจะส่งกระทบต่อเนื่องไปยังการให้บริการ สาธารณะของท้องถิ่นหรือไม่ อย่างไร ( 10 นาที

2d. ท่านคิดว่าวิกฤติการเมืองระดับชาติจะส่งผลทางบวกหรือทางลบต่อการบริหารท้องถิ่นและต่อ การบริการสาธารณะของท้องถิ่นไหม ทำไมท่านคิดเช่นนั้น (5 นาที)

3. ผมคิดว่าการจัดการในสภาวะวิกฤติเป็นกลยุทธ์ที่สำคัญในการบริหารองค์กรสมัยใหม่ ผมอยากให้ท่าน ได้เล่าได้ไหมครับว่า เทศบาลของท่านได้จัดการรองรับผลกระทบอันเกิดจากวิกฤติการเมืองอันลากยาวครั้ง นี้ อย่างไรบ้าง (5 นาที)

ช่วยแลกเปลี่ยนประสบการณ์ของท่านได้เลยนะครับ โดยเฉพาะเกี่ยวกับการบริหารองค์กรใน สภาวะวิกฤติการเมืองและกลยุทธ์การบริหารต่างๆ ที่ท่านนำมาใช้ในการรองรับภาวะวิกฤติการเมืองท่าน สามารถพูดถึงผลลัพธ์ของการใช้กลยุทธ์นั้นๆด้วยนะครับ รวมถึงวิธีการปรับปรุงในอนาคต

4. เรามาถึงช่วงสุดท้ายของการสนทนากลุ่มแล้วนะครับ ท่านสามารถยกประเด็นที่เราอาจจะไม่ได้สนทนา กันและท่านเห็นว่ามีความสำคัญและเป็นประโยชน์ได้นะครับ โดยผมจะให้เวลาท่านทบทวนสักครู่หนึ่งนะ ครับ และผมอยากให้ทุกท่านได้กล่าวสรุปสั้นๆ เป็นรายบุคคลรอบโต๊ะนะครับ (5 นาที)

ผมขอขอบพระคุณทุกท่านมากๆนะครับ สำหรับการร่วมสนทนากลุ่มในครั้งนี้ หลังจากนั้นตรวจสอบความเรียบร้อยของแบบฟอร์มการยินยอมให้สัมภาษณ์และการบันทึกเสียง 


\section{ส่วนที่ 1: บทนำ}

\section{คำถามสัมภาษณ์การประชุมกลุ่ม สำหรับผู้นำชุมชน และ ประชาชนทั่วไป}

- ผมเริ่มต้นการสัมภาษณ์ด้วยการแนะนำข้อมูลของตนเองที่เกี่ยวข้องกับการศึกษา เป้าหมายการวิจัย และ หลังจากนั้นก็เปิดโอกาสให้ผู้ให้สัมภาษณ์ได้แนะนำตัวเอง โดยระบุชื่อนามสกุล และบทบาทหน้าที่ใน ชุมชนท้องถิ่น

- อธิบายข้อมูลเกี่ยวกับการกรอกแบบฟอร์มยินยอมให้สัมภาษณ์และแจ้งผู้ให้สัมภาษณ์ลงนามใน แบบฟอร์มนั้นหากยินดีร่วมการสัมภาษณ์ นอกจากนั้นขออนุญาตบันทึกเสียงขณะสัมภาษณ์

ส่วนที่ 2: คำถามสัมภาษณ์

1. ท่านในฐานะที่มีบทบาทในฐานะประชาชนที่เป็นหุ้นส่วนสำคัญในองค์กรปกครองส่วนท้องถิ่น ซึ่งผมคิดว่า วิกฤติการเมืองที่เกิดขึ้นในระดับชาติลากยาวมาตั้งแต่ปี 2549 อาจจะส่งผลกระทบต่อการดำรงชีวิตของท่าน โดยเฉพาะที่เกี่ยวข้องกับการบริการสาธารณะของท้องถิ่น ดังนั้นผมอยากจะฟังเรื่องราวต่างๆที่เกิดขึ้น เกี่ยวกับวิกฤติการเมืองไทยและผลกระทบทีเกิดขึ้น ที่ท่านอาจจะได้รับข้อมูลจากสื่อต่างๆ หรือท่านอาจจะ ประสบด้วยตนเอง (5 นาที)

เราจะเริ่มการสนทนาโดยให้ทุกท่านได้แลกเปลี่ยนความเห็นเกี่ยวกับสภาวะวิกฤติการเมือง และ หากท่านสามารถระบุประเด็นที่มีส่วนเกี่ยวพันกับองค์กรปกครองส่วนท้องถิ่น ที่ท่านเคยได้รับรู้มาจาก แหล่งต่างๆ ไม่ว่าจะเป็นจากข่าวหรือสื่อต่างๆ ผมจะแจกแผ่นกระดาษโพสอิทให้ทุกท่านได้เขียนประเด็นที่ ท่านรับรู้เกี่ยวกับภาวะวิกฤติการเมืองในทัศนะของท่าน ลงในกระดาษ และหลังจากนั้นผมจะให้แต่ละท่าน ได้ร่วมแลกเปลี่ยนความเห็น

1a. ท่านได้ติดตามข่าวเกี่ยวกับวิฤติการเมืองไทยบ้างไหมครับ เรามาแลกเปลี่ยนกันในประเด็นนี้ กันนะครับ (5 นาที)

2. นี่เป็นการเริ่มต้นการสนทนาที่ดีมากเลยนะครับ พวกเราได้เรียนรู้จากเรื่องราวที่เกิดขึ้นที่ทุกท่านได้ร่วม แลกเปลี่ยน โดยเฉพาะเรื่องผลกระทบที่เกิดกับตัวท่านและชุมชนของท่าน ต่อไปเรามาคุยลงลึกถึงผลกระทบ ของภาวะวิกฤติการเมืองระดับชาติที่ส่งผลต่อการบริการสาธารณะของท้องถิ่นกันนะครับ ท่านคิดว่าวิกฤติ การเมืองที่เกิดขึ้น ส่งผลกระทบต่อหน้าที่หลักของท้องถิ่นทั้ง 6 ประการในการให้บริการสาธารณะแก่พวก ท่านไหมครับ อยากให้ท่านได้ระบุเป็นชัดๆที่เกิดขึ้นในห้วงตั้งแตีปี 2549 ถึงปัจจุบันครับ (10 นาที) ท่านสามารถแลกเปลี่ยนประเด็นที่ท่านอยากนำเสนอได้ตามสะดวกเลยนะครับ ท่านอาจจะพูดถึง ประเด็นใดก่อนก็ได้ รบกวนทุกท่านแลกเปลี่ยนและนำเสนอให้ได้มากที่สุดเท่าที่ท่านต้องการครับนะครับ โดยผมเน้นประเด็นที่ส่งผลกระทบโดยตรงต่อชุมชนท้องถิ่นและต่อการบริการสาธารณะที่ท่านได้รับ 
2a. ท่านเป็นหุ้นส่วนที่สำคัญมากในองค์กรปกครองส่วนท้องถิ่น ในช่วงที่เกิดวิกฤติการเมือง ระดับชาติ ท่านคิดว่าท้องถิ่นยังคงสามารถให้บริการสาธารณะแก่ชุมชนของท่านได้เช่นเดิมไหม ทำไมถึงคิด ว่าเป็นเช่นนั้นครับ ลองยกตัวอย่างได้ไหมครับ ( 10 นาที)

2b. มีหลายปัจจัยทางการบริหารท้องถิ่นที่อาจจะได้รับผลกระทบจากวิกฤติการเมืองที่ลากยาว เช่น สถาบันการเมือง ภาวะผู้นำ การมีส่วนร่วมของภาคประชาชน การประสานความร่วมมือและเครือข่าย การ บริหารการเงินการคลัง ตลอดจนสภาพเศรษฐกิจ ในท้องถิ่น ท่านคิดว่าวิกฤติการเมืองระดับชาติส่งผลต่อ ปัจจัยแทรกซ้อนเหล่านี้ไหม และท้ายสุดปัจจัยเหล่านี้ที่ได้รับผลกระทบจะส่งกระทบต่อเนื่องไปยังการ ให้บริการสาธารณะของท้องถิ่นหรือไม่ อย่างไร ( 10 นาที)

2c. ท่านคิดว่าวิกฤติการเมืองระดับชาติจะส่งผลทางบวกหรือทางลบต่อการบริหารท้องถิ่นและต่อ การบริการสาธารณะของท้องถิ่นไหม ทำไมท่านคิดเช่นนั้น (10 นาที)

3. ผมคิดว่าการจัดการในสภาวะวิกฤติเป็นกลยุทธ์ที่สำคัญในการบริหารองค์กรสมัยใหม่ ผมอยากให้ท่าน ได้เล่าได้ไหมครับว่า เทศบาลของท่านได้จัดการรองรับผลกระทบอันเกิดจากวิกฤติการเมืองอันลากยาวครั้ง นี้ อย่างไรบ้าง และเทศบาลได้เปิดโอกาสให้ภาคประชาชนชุมชนท้องถิ่นมีส่วนร่วมในกระบวนการบริหาร จัดการกับภาวะวิกฤตินี้อย่างไรบ้าง ( 10 นาที)

ช่วยแลกเปลี่ยนประสบการณ์ของท่านได้เลยนะครับ โดยเฉพาะที่ท่านเห็นว่า ท้องถิ่นใช้กลยุทธ์ ต่างๆ ในการรับมือหรือแก้ปัญหาต่างๆ ในสภาวะวิกฤติการเมืองระดับชาติ เพื่อรักษาและคงไว้ซึ่งการบริการ สาธารณะของท้องถิ่น ตลอดจนการเอาภาคประชาชนเข้าไปมีส่วนร่วมในขั้นตอนต่างๆ

4. เรามาถึงช่วงสุดท้ายของการสนทนากลุ่มแล้วนะครับ ท่านสามารถยกประเด็นที่เราอาจจะไม่ได้สนทนา กันและท่านเห็นว่ามีความสำคัญและเป็นประโยชน์ได้นะครับ โดยผมจะให้เวลาท่านทบทวนสักครู่หนึ่งนะ ครับ และผมอยากให้ทุกท่านได้กล่าวสรุปสั้นๆ เป็นรายบุคคลรอบโต๊ะนะครับ (5 นาที)

ผมขอขอบพระคุณทุกท่านมากๆนะครับ สำหรับการร่วมสนทนากลุ่มในครั้งนี้ หลังจากนั้นตรวจสอบความเรียบร้อยของแบบฟอร์มการยินยอมให้สัมภาษณ์และการบันทึกเสียง 


\section{Appendix E}

\section{Informed Consent Form}

You are invited to participate in an interview that will be conducted by Sirisak Laochankham, a Ph.D. Candidate in Public Affairs and Policy, Mark O. Hatfield School of Government, College of Urban and Public Affairs, Portland State University. The goal of this interview is to explore the effects of national political crises on local public service delivery in upper Northeast Thailand.

If you decide to be part of this interview, you will be asked to participate in either an indepth interview or a focus group interview; both types of interviews will take about one hour to complete. The interview will be recorded and a transcript will be used for doctoral dissertation and educational purposes. The information will be used for research, including publication in scholarly journals.

Your participation in this interview is entirely voluntary. If you decide to participate, you can stop at any time without any effect on your relationship with me, Portland State University, your local government, or anyone else associated with this interview. In addition to signing this form, you will receive another copy to keep for your own records. Any information that is obtained in connection with this interview will be kept confidential by the researcher, and any identifying information will be removed. Specifically, any use of these recordings will require the removal of:

1. Your name and any other information that would make it possible to identify you;

2. The name and any other information that would make it possible to identify any other person or organization that you mention during the interview, including your local government/local community.

However, confidentiality cannot be guaranteed in a group setting. Please respect one another's privacy by not repeating what was said at the meeting or who attended.

If you have concerns or problems about your participation in this interview, you may contact:

Human Subjects Research Committee Research and Strategic Partnerships (RSP) P.O. 751

Portland OR 97207-0751 (503) 725-4288 hsrrs@ lists.pdx.edu

If you have any questions about the interview itself, you may contact:

Sirisak Laochankham, Ph.D. Candidate in Public Affairs and Policy,

Mark O. Hatfield School of Government, College of Urban and Public Affairs,

Portland State University (573) 529-4773 sirisak@pdx.edu

Name of Interviewee (type or print)

(Signature of Interviewee)

(Date) 


\title{
Appendix F
}

\section{Informed Consent Form [In Thai]}

\author{
หนังสือยินยอมให้สัมภาษณ์
}

ท่านได้รับเชิญเข้าร่วมการสัมภาษณ์ ที่ดำเนินการสัมภาษณ์โดย นายศิริศักดิ์ เหล่าจันขาม นักศึกษาปริญญาเอก สาขา กิจการสาธารณะและนโยบายสาธารณะ ภาควิชาการปกครอง มาร์ค โอ แฮทฟิลด์ วิทยาลัยกิจการเมืองและกิจการสาธารณะ มหาวิทยาลัยพอตแลนด์สเตท วัตถุประสงค์ของการสัมภาษณ์ครั้งนี้เพื่อศึกษาผลกระทบอันเกิดจากวิกฤติการเมืองระดับชาติที่ ส่งผลต่อการบริการสาธารณะขององค์กรปกครองส่วนท้องถิ่นในภาคตะวันออกเฉียงเหนือของประเทศไทย หากท่านตัดสินใจ ยินดีเข้าร่วมการสัมภาษณ์ครั้งนี้ ท่านจะได้รับการร้องขอให้ร่วมการสัมภาษ์เดี่ยวเชิงลึกหรือการสนทนากลุ่ม โดยการสัมภาษณ์ จะใช้เวลาประมาณไม่เกิน 1 ชั่วโมง การสัมภาษณ์ครั้งนี้จะมีการบันทึกเทป และการถอดเทปสัมภาษณ์เพื่อนำไปใช้ในการ วิเคราะห์ข้อมูลในการเขียนดุษฎีนิพนธ์ระดับปริญญาเอกและกิจกรรมทางการศึกษาอื่นๆ ข้อมูลต่างๆที่ได้รับจากท่านจะใช้ใน การทำวิจัย รวมถึงการเผยแพร่ตีพิมพ์ในวารสารวิชาการ

การเข้าร่วมสัมภาษณ์ครั้งนี้ถือว่าเป็นความสมัครใจ หากท่านไม่ประสงค์จะร่วมสัมภาษณ์ท่านสามารถหยุดการให้ สัมภาษณ์ได้ทุกเวลาโดยจะไม่มีผลต่อสัมพันธภาพใดกับข้าพเจ้า มหาวิทยาลัยพอตแลนด์สเตท องค์กรปกครองส่วนท้องถิ่น ของท่าน หรือบุคคลอื่นใดที่เกี่ยวข้องกับการสัมภาษณ์นี้ หลังจากที่ท่านลงชื่อในแบบแสดงความยินยอมนี้แล้ว ท่านจะได้รับ สำเนาอีกหนึ่งฉบับเพื่อเก็บไว้เป็นหลักฐาน ข้อมูลทุกอย่างที่เกี่ยวข้องกับการสัมภาษณ์นี้ จะเก็บไว้อย่างมิดชิดและรักษาความ เป็นส่วนตัวของท่านโดยนักวิจัย รวมถึงข้อมูลอื่นๆที่แสดงให้เห็นความเป็นส่วนตัวของท่านจะถูกลบออก โดยเฉพาะข้อมูล ส่วนบุคคลดังต่อไปนี้จะถูกลบออก:

1. ชื่อของท่านและข้อมูลอื่นๆที่สามารถสื่อถึงตัวท่านได้

2. ชื่อหรือข้อมูลอื่นๆ ที่อาจจะสื่อถึงบุคคลหรือองค์กรอื่นๆ ที่ท่านกล่าวถึงในระหว่างการสัมภาษณ์ รวมถึงชื่อของเทศบาลและชื่อของหมู่บ้านท่าน

อย่างไรก็ตาม ความเป็นส่วนตัวข้างต้นไม่สามารถรับรองได้ในการประชุมกลุ่ม โปรดเคารพในความเป็นส่วนตัวซึ่ง กันและกันโดยไม่ต้องไปกล่าวซ้ำถึงอะไรก็ตามที่สนทนากันในการประชุมกลุ่มหรือบ่งบอกถึงผู้เข้าร่วมประชุม หากท่านมีข้อ ห่วงใยหรือมีปัญหาใดๆ เกี่ยวกับการเข้าร่วมสัมภาษณ์ในครั้งนี้ ท่านสามารถติดต่อได้ที่ สำนักงานคณะกรรมการการวิจัยใน มนุษย์และความร่วมมือ ที่ ตู้ ป.ณ. 751 เมืองพอตแลนด์ รัฐออริกอน สหรัฐอเมริกา โทรศัพท์ 97207-0751 (503) 725-4288 อีเมล์ hsrrs@lists.pdx.edu หรือหากมีข้อสงสัยเกี่ยวกับการสัมภาษณ์ ท่านสามารถติดต่อที่ นายศิริศักดิ์ เหล่าจันขาม นักศึกษาปริญญา เอก สาขากิจการสาธารณะและนโยบายสาธารณะ ภาควิชาการปกครอง มาร์ค โอ แฮทฟิลด์ วิทยาลัยกิจการเมืองและกิจการ สาธารณะ มหาวิทยาลัยพอตแลนด์สเตท โทรศัพท์ 081-7174430 อีเมล์ sirisak@pdx.edu

ชื่อผู้ให้สัมภาษณ์ (พิมพ์หรือตัวบรรจง)

(ลายมือชื่อผู้ให้สัมภาษณ์)

(วันที่สัมภาษณ์) 


\section{Appendix G}

\section{Letter of Request for Interview Permission from Local Government}

Public Affairs and Policy Ph.D. Program, Mark O. Hatfield School of Government, Portland State University, P. O. Box 751, Portland, OR 97207-0751

Date...., 2016

Dear (Name \& Title of Municipal Mayor or Appropriate Person),

My name is Sirisak Laochankham. I am a Ph.D. candidate in Public Affairs and Policy at Hatfield School of Government, College of Urban and Public Affairs, Portland State University, Oregon, the United States of America. As part of my dissertation I am conducting a research study titled: "Local Government Service Delivery under Crisis Conditions: The Case of Thailand". The purpose of the research is to explore the effects of national political crisis on local government service delivery and discover the coping strategies and mechanisms that local governments use in times of political crisis in Thailand.

This research is a case study that uses both face-to-face, semi-structured interviews and focusgroup interviews to collect the data from the targeted participants. Prior to conducting the interviews, I would like to request for your permission to approach the following targeted participants: municipal mayor, municipal councilors, municipal division managers, municipal officers, community leaders, and local residents within your municipality to take part in the study. I will recruit the targeted participants to the study using phone and person to person conversation. I expect to recruit approximately 10-13 of participants.

I can assure you that I will make every effort to ensure the interviews do not disturb the working environment in any way and data collection will remain highly confidential. I am applying ethical approval for the interviews from Human Subjects Research Review Committee, Office of Research and Strategic Partnerships at Portland State University, the United States of America.

My dissertation research is supervised by Dr. Bruce Gilley, a professor of political science, Mark O. Hatfield School of Government, College of Urban and Public Affairs, Portland State University. If you have any question please contact (503) 725-3056 or email: gilleyb@pdx.edu.

Yours Sincerely,

(Sirisak Laochankham)

Ph.D. candidate in Public Affairs and Policy

Contact email: sirisak@pdx.edu

Mobile phone: USA-573-529-4773, Thailand-081-7174430 


\section{Appendix H}

\section{Letter of Request for Interview Permission from Local Government (In Thai)}

หลักสูตรปริญญาเอกกิจการสาธารณะและนโยบายสาธารณะ

ภาควิชาการปกครอง มาร์ค โอ แฮทฟิลด์, วิทยาลัยกิจการเมืองและกิจการสาธารณะ

มหาวิทยาลัยพอตแลนด์สเตท ตู้ ป.ณ. 751 เมืองพอตแลนด์ รัฐออริกอน 97207-0751

วันที่ ……………………....2559

เรื่อง ขออนุญาตเก็บข้อมูลวิจัยปิญญาเอก

เรียน (ชื่อ/ตำแหน่งนายกเทศมนตรี)

ข้าพเจ้าชื่อ นายศิริศักดิ์ เหล่าจันขาม เป็นนักศึกษาปริญญาเอก สาขากิจการสาธารณะและนโยบายสาธารณะภาค วิชาการปกครอง มาร์ค โอ แฮทฟิลด์ วิทยาลัยกิจการเมืองและกิจการสาธารณะ มหาวิทยาลัยพอตแลนด์สเตท สหรัฐอเมริกา ข้าพเจ้ากำลังทำการวิจัยหัวข้อ “การบริการสาธารณะขององค์กรปกครองส่วนท้องถิ่น ภายใต้สภาวะวิกฤติ: กรณีศึกษาประเทศ ไทย" อันเป็นส่วนหนึ่งในการศึกษาปริญญาเอกของข้าพเจ้า วัตถุประสงค์ของการวิจัยครั้งนี้เพื่อศึกษาผลกระทบอันเกิดจาก วิกฤติการเมืองระดับชาติที่ส่งผลต่อการบริการสาธารณะขององค์กรปกครองส่วนท้องถิ่นในภาคตะวันออกเฉียงเหนือของ ประเทศไทย งานวิจัยนี้เป็นการศึกษากรณีศึกษาโดยใช้การสัมภาษณ์เดี่ยวแบบเชิงลึก และการสนทนากลุ่มจากผู้เข้าร่วมการ สัมภาษณ์ ก่อนที่จะดำเนินการสัมภาษณ์ ข้าพเจ้าจึงใคร่ขออนุญาตท่านสัมภาษณ์บุคลากรในหน่วยงานของท่านและประชาชน ในเขตเทศบาลของท่านโดยขอความอนุเคราะห์ท่านในการคัดเลือกและติดต่อบุคคลที่มีตำแหน่งต่อไปนี้ในเทศบาลของท่านเข้า ร่วมการสัมภาษณ์ประกอบด้วย นายกเทศมนตรี ประธานสภาเทศบาล สมาชิกสภาเทศบาล ผู้อำนวยการกองหรือหัวหน้าส่วน งาน รวมถึงผู้นำชุมชนและประชาชน ข้าพเจ้าจะประสานคัดเลือกผู้เข้าสัมภาษณ์ทางโทรศัพท์หรือติดต่อพบตัวต่อตัว โดยหวัง อยากจะได้ผู้เข้าสัมภาษณ์ประมาณ $10-13$ คน

ข้าพเจ้าขอยืนยันว่า ข้าพเจ้าจะพยายามทุกวิถีทางในการสร้างความมั่นใจว่า การสัมภาษณ์จะไม่กระทบกับการทำงาน ประจำและจะรักษาความเป็นส่วนตัวของผู้ให้สัมภาษณ์ไว้เป็นอย่างดี ทั้งนี้ ข้าพเจ้าได้รับความเห็นชอบจากคณะกรรมการวิจัย ในมนุษย์และยุทธศาสตร์ความร่วมมือของมหาวิทยาลัยพอตแลนด์สเตท สหรัฐอเมริกา แล้ว ดุษฎีนิพนธ์ของข้าพเจ้า อยู่ภายใต้การให้คำปรึกษาของ ดร.บรูซ กิลลี ศาสตราจารย์ด้านรัฐศาสตร์ จากภาควิชาการ ปกครอง มาร์ค โอ แฮทฟิลด์ วิทยาลัยกิจการเมืองและกิจการสาธารณะ มหาวิทยาลัยพอตแลนด์สเตท หากท่านมีข้อสงสัยใดๆ โปรดติดต่อ (503) 725-3056 หรืออีเมล์ gilleyb@pdx.edu.

ขอแสดงความนับถือ

(นายศิริศักดิ์ เหล่าจันขาม)

นักศึกษาปริญญาเอก สาขากิจการสาธารณะและนโยบาย

อีเมล์ sirisak@pdx.edu มือถือ 081-7174430 


\section{Appendix I}

Examples of Codebook for Interview Data Analysis

\begin{tabular}{|c|c|c|c|}
\hline $\begin{array}{c}\text { Moderating } \\
\text { Variable }\end{array}$ & Code & Description & Example of Data Excerpt \\
\hline \multirow[t]{2}{*}{$\begin{array}{l}\text { Political } \\
\text { Institutions }\end{array}$} & $\begin{array}{l}\text { Lack of } \\
\text { representation }\end{array}$ & $\begin{array}{l}\text { Participant refers to the } \\
\text { effect of electoral } \\
\text { suspension eliminating the } \\
\text { roles of elected } \\
\text { representatives. }\end{array}$ & $\begin{array}{l}\text { “...Nowadays, it seems like } \\
\text { we don't have people who } \\
\text { represent us. We don't have } \\
\text { people who can help us. It's } \\
\text { broken and disconnected." }\end{array}$ \\
\hline & $\begin{array}{l}\text { Facilitating local } \\
\text { administrative } \\
\text { procedures }\end{array}$ & $\begin{array}{l}\text { Participant refers to the } \\
\text { legal mechanism (i.e. } \\
\text { Section 44) that the junta } \\
\text { government used for } \\
\text { solving complicated } \\
\text { procedures in } \\
\text { governmental } \\
\text { administration. }\end{array}$ & $\begin{array}{l}\text { "Frankly speaking, I would } \\
\text { say that in the absence of an } \\
\text { [elected] government, when } \\
\text { we needed something, Section } \\
44 \text { provided a convenience for } \\
\text { us. It makes things easier for } \\
\text { us. It's convenient. In the past, } \\
\text { we had to get approval from } \\
\text { the provincial governor or } \\
\text { district chief officer. Section } \\
44 \text { can order and terminate the } \\
\text { inconvenient issues or the } \\
\text { limitations of those } \\
\text { regulations in order to } \\
\text { facilitate our work when we } \\
\text { want to assist people." }\end{array}$ \\
\hline \multirow[t]{2}{*}{$\begin{array}{l}\text { Civic } \\
\text { Engagement }\end{array}$} & Political fears & $\begin{array}{l}\text { Participant refers to fears } \\
\text { caused by political crisis } \\
\text { and the junta laws } \\
\text { prohibiting political } \\
\text { engagement. }\end{array}$ & $\begin{array}{l}\text { "Nowadays, municipality } \\
\text { avoided organizing the } \\
\text { activity that may involve in } \\
\text { politics. They were afraid of } \\
\text { being investigated for a } \\
\text { gathering of more than four } \\
\text { persons. Some people said, } \\
\text { any activity that was } \\
\text { organized by municipality, I } \\
\text { didn't want go." }\end{array}$ \\
\hline & $\begin{array}{l}\text { Eager to speak } \\
\text { out and involving } \\
\text { in local decision- } \\
\text { making }\end{array}$ & $\begin{array}{l}\text { Participant refers to civic } \\
\text { participation improved at } \\
\text { local level, especially in } \\
\text { local affairs. }\end{array}$ & $\begin{array}{l}\text { "When we had a town hall } \\
\text { meeting, local citizens were } \\
\text { actively engaged in the } \\
\text { meeting. They shared their } \\
\text { thoughts on development } \\
\text { projects." }\end{array}$ \\
\hline
\end{tabular}




\begin{tabular}{|c|c|c|c|}
\hline $\begin{array}{l}\text { Political } \\
\text { Leadership }\end{array}$ & $\begin{array}{l}\text { Fears to do thing } \\
\text { wrong }\end{array}$ & $\begin{array}{l}\text { Participant refers to the } \\
\text { effects of legal constraints } \\
\text { on decision-making of } \\
\text { local leaders. }\end{array}$ & $\begin{array}{l}\text { "It looks like we did } \\
\text { everything wrong. Why I have } \\
\text { to do that? I can't sleep and I } \\
\text { am concerned about what I } \\
\text { don't want to do. I want to do } \\
\text { the things that local residents } \\
\text { agree is good for them. When } \\
\text { we do something, the national } \\
\text { auditing office told us that we } \\
\text { were non-compliant on that } \\
\text { project. We've encountered } \\
\text { difficulties. We would like to } \\
\text { do right, but at least they } \\
\text { should provide us the right } \\
\text { laws that help avoid the act of } \\
\text { non-compliance. We're happy } \\
\text { if having that." }\end{array}$ \\
\hline & $\begin{array}{l}\text { More recognition } \\
\text { of local leaders }\end{array}$ & $\begin{array}{l}\text { Participant refers to } \\
\text { positive perceptions of } \\
\text { local residents on their } \\
\text { local leaders in times of } \\
\text { political crisis. }\end{array}$ & $\begin{array}{l}\text { "I don't know how about the } \\
\text { mayor in other places, but our } \\
\text { mayor went everywhere } \\
\text { whenever he knew there was a } \\
\text { problem, responding to the } \\
\text { request of local citizens. At } \\
\text { least, he can help coordinate } \\
\text { and provide some basic help. } \\
\text { He is concerned about the } \\
\text { community's needs and never } \\
\text { ignored what we needed." }\end{array}$ \\
\hline Governance & $\begin{array}{l}\text { More centralized } \\
\text { administration }\end{array}$ & $\begin{array}{l}\text { Participant refers to the } \\
\text { interaction between central } \\
\text { and local government was } \\
\text { more hierarchical in the } \\
\text { midst of crisis (e.g. top- } \\
\text { down). }\end{array}$ & $\begin{array}{l}\text { "These things are ordered by } \\
\text { central government. The } \\
\text { government directed central } \\
\text { ministries and central } \\
\text { departments. Those central } \\
\text { authorities then ordered the } \\
\text { Ministry of Interior. After } \\
\text { that, the Ministry of Interior } \\
\text { delivered an order to } \\
\text { provincial and district } \\
\text { authorities. The districts then } \\
\text { ordered local governments. } \\
\text { This is the pattern of their } \\
\text { work." }\end{array}$ \\
\hline
\end{tabular}




\begin{tabular}{|c|c|c|c|}
\hline & $\begin{array}{l}\text { Active reaction to } \\
\text { local issues }\end{array}$ & $\begin{array}{l}\text { Participant refers to local } \\
\text { governments actively } \\
\text { responding to solve local } \\
\text { problems. }\end{array}$ & $\begin{array}{l}\text { "Local governments expanded } \\
\text { very fast in order to respond } \\
\text { to the developments. We are } \\
\text { with local citizens every day. } \\
\text { If people complain about the } \\
\text { bad roads in our community, } \\
\text { we have to provide budget in } \\
\text { order to respond to that } \\
\text { problem immediately. In the } \\
\text { past, it took more than ten } \\
\text { years to get a gravel road, but } \\
\text { nowadays it is very fast." }\end{array}$ \\
\hline \multirow[t]{2}{*}{$\begin{array}{l}\text { Political } \\
\text { Economy }\end{array}$} & $\begin{array}{l}\text { Uncertain to } \\
\text { spend money or } \\
\text { invest in business }\end{array}$ & $\begin{array}{l}\text { Participant refers to } \\
\text { political instability causing } \\
\text { uncertainty for spending } \\
\text { and investing in some } \\
\text { local businesses. }\end{array}$ & $\begin{array}{l}\text { "...Wherever I went, I heard } \\
\text { people complain about } \\
\text { economic constraints. It's } \\
\text { difficult for them to make any } \\
\text { money. It also affected me. } \\
\text { My wife runs a grocery store } \\
\text { business; she said her business } \\
\text { was not good. She observed a } \\
\text { decline of consumption. It } \\
\text { looks like people work but } \\
\text { they did not earn good } \\
\text { income. When people have } \\
\text { less money to spend, it caused } \\
\text { the decline of money to spend } \\
\text { in our local community." }\end{array}$ \\
\hline & $\begin{array}{l}\text { Central } \\
\text { facilitation }\end{array}$ & $\begin{array}{l}\text { Participant refers to } \\
\text { intervention of central } \\
\text { government rather help to } \\
\text { support local development. }\end{array}$ & $\begin{array}{l}\text { "Currently, our economic } \\
\text { status is gradually recovering } \\
\text { because the military-installed } \\
\text { government has boosted the } \\
\text { local economy through the } \\
\text { provincial administration. } \\
\text { Local people can earn income } \\
\text { of about } 300 \text { THB per day. It } \\
\text { took just two months. It [the } \\
\text { state-led development project] } \\
\text { helped stimulate local } \\
\text { economies. Local people have } \\
\text { money to spend in the } \\
\text { market." }\end{array}$ \\
\hline
\end{tabular}

